\title{
Advisors' attitudes toward developmental placement and the academic performance and perceived success of their underprepared community college advisees
}

June Elizabeth Bracken

West Virginia University

Follow this and additional works at: https://researchrepository.wvu.edu/etd

\section{Recommended Citation}

Bracken, June Elizabeth, "Advisors' attitudes toward developmental placement and the academic performance and perceived success of their underprepared community college advisees" (2004). Graduate Theses, Dissertations, and Problem Reports. 2552.

https://researchrepository.wvu.edu/etd/2552

This Dissertation is protected by copyright and/or related rights. It has been brought to you by the The Research Repository @ WVU with permission from the rights-holder(s). You are free to use this Dissertation in any way that is permitted by the copyright and related rights legislation that applies to your use. For other uses you must obtain permission from the rights-holder(s) directly, unless additional rights are indicated by a Creative Commons license in the record and/ or on the work itself. This Dissertation has been accepted for inclusion in WVU Graduate Theses, Dissertations, and Problem Reports collection by an authorized administrator of The Research Repository @ WVU.

For more information, please contact researchrepository@mail.wvu.edu. 
Advisors' Attitudes

Toward Developmental Placement and the

Academic Performance and Perceived

Success of Their Underprepared Community College Advisees

June Elizabeth Bracken

Dissertation submitted to the College of Human Resources and Education at West Virginia University in partial fulfillment of the requirements

for the degree of

Doctor of Education

in

Educational Leadership

Elizabeth Jones, Ph.D., Chair

Richard Hartnett, Ed.D.

Ernest Goeres, Ph.D.

Richard Walls, Ph.D.

H. Eugene Hall, Ed.D.

Department of Advanced Educational Studies

Morgantown, West Virginia

2004

Keywords: Academic Advising Models, Retention, Remediation Copyright 2004 June E. Bracken 


\title{
ABSTRACT \\ Advisors' Attitudes Toward Developmental Placement and the Academic Performance and Perceived Success of Their Underprepared Community College Advisees
}

\author{
June E. Bracken
}

\begin{abstract}
Open admissions policies pose a critical challenge to retention at community colleges because, on average, over one third of the students enter unprepared to meet the academic demands. Faced with the shocking first-year attrition rate of over fifty percent at public community colleges (McCabe, 2000), taxpayers, legislators, and college officials have become embroiled in debate over the high cost of remediation and the "human capital" (Shaffer, 1997, 1998) costs of pitting access against excellence. Previous research has established that
\end{abstract} mandatory basic skills assessment and mandatory placement into developmental courses leads to lower attrition rates and higher grade point averages for underprepared students. Research also has shown that academic advising plays a critical role in improving student retention. This research project examined both developmental placement policies and the advisor/advisee relationship from a new perspective, through the lens of advisors' attitudes.

This research explored the possibility that advisors hold preconceived views toward underprepared students and distinct opinions about the responsibility community colleges hold in providing them with access to higher education. It explored whether advisors' attitudes toward both underprepared students and the policies that direct course placement are related to the way the advisors view and carry out their role as advisor and, by extension, whether underprepared students' academic performance and perceived success is related to advisors' attitudes. Attitudes were measured on two researcher-constructed surveys.

Two overarching hypotheses guided the study. The first hypothesis $\left(\mathrm{H}_{1}\right)$ was that advisors perform their advising duties in accordance with their attitudes or belief systems. $\mathrm{H}_{1}$ gained statistical support. The second $\left(\mathrm{H}_{2}\right)$ was that advisors' attitudes toward underprepared students and toward developmental placement policies are related to their advisees' subsequent academic performance and perceived success. A relationship between advisors' attitudes and students' academic performance, as measured by course grades and completion rates, was not established. However, a small but significant relationship was found between students' perceptions of their advisors' attitudes and their own academic performance. Also, qualitative data indicated that students perceived a positive influence on their success from talking to their advisors. 


\section{DEDICATION}

I dedicate this volume to two great leaders:

To my grandmother, Bess Willis Shrader, a politically active and influential member of the school board and society, and to her sister, Martha Willis Rutrough, a quietly passionate member of the church and community.

Bess opened doors for me, and Marty taught by example how to value each step of the journey. 


\section{ACKNOWLEDGEMENTS}

Before I began this doctoral program, I had never considered studying higher education leadership. In fact, I never imagined myself studying or becoming a leader of any sort. I realize now that we are all leaders, some in obvious ways and others through quiet example. Long before my first trip to Morgantown, countless individuals helped shape my life’s direction. For instance, I’m not sure that I would have loved reading so much if my mother hadn't shared bedtime stories with me during that critical period when I was very young, and I might not have believed I had anything worth saying if my friend Nila hadn’t listened so intently during that awkward adolescent phase. What if I hadn't had bad experiences in school that made me want to change the system, or if I hadn’t worked with students who helped me look beyond the system to focus on the hearts of individuals? I believe that God sends us the people we need and guides us toward people who need us, and with each interaction, we are changed. I am grateful to all who have led me to become the person I am today.

This stage of the journey, the last four years in the doctoral cohort program, has not been easy, and yet it has been a time of intensive growth for which I am extremely grateful. My parents, Tom and Fran Bracken, have been my strongest supporters. Their belief in me and in the importance of what I'm doing has helped me persist to completion. I am grateful to my family and friends for their loving understanding of all the missed birthdays, holidays, and important events and outings: Julie, Norm, Josh, Justin, Jennifer, and Jessica; Tim, Jan, Tommy, Andy, Coby, and Katie; Bill, Mary, Becky, and Elizabeth; Nila, Chris, Shawn, Mary, Nan, Bettie, Mary, and Maureen. I have felt their love and support even when they could see no evidence of mine. And I am grateful to my furry and feathered family members for their lifegiving energy and comfort: to my sweet Sasha, my English Sheepdog mix who didn’t make it to 
the end, but who has been with me since my first teaching job. She taught me a great deal about embracing those with special needs. And to Coffee, my Golden Retriever mix, who lives in the moment and lives to love. He has taught me that sometimes a good game of fetch is more important than any other endeavor; the rest will wait. And to Toby, my Severe Macaw, who makes me laugh with her antics. She tells me every day—literally TELLS me—-It's oooo-kay. Dooon't worry. You're Beauuu-tiful!” What more could one ask?

Drs. Jones and Hartnett started West Virginia University’s doctoral cohort program in higher education leadership. Without their ingenuity and creative approach to scheduling, the16 members of Cohort One would not have been able to complete doctoral degrees while maintaining our full-time professional responsibilities. The cohort program did not make completion of our doctorates easy, but it did make it possible, and I am grateful for the opportunity. Dr. Jones and Dr. Hartnett persevered through budget cuts and personnel reallocations to keep the cohort running. I am also grateful to the cohort members. Each of us contributed a wealth of educational experience and knowledge to class discussions and projects. I have learned a great deal from each member. My special thanks go to the "home" contingent of the cohort for both comfort and camaraderie: Bettie, Rick, Ester, Bev, Bill, and Lisa.

My strongest professional supporter has been Dr. Gene Hall. He has demonstrated his belief in me by entrusting me with more and more responsibility over the years. (And he has supported me by entrusting me with a little less this past semester so I'd have time to write my dissertation findings!) He and Dr. Alexander have been strong supporters of the doctoral cohort program, and I wouldn't be here if it weren't for them. My division chair, Jim Zamagias, is the most generous spirit I know, and I will be eternally grateful for his care, moral support, and copy-editing. Also, I could not have completed this research project without the cooperation of 
my colleagues. Eighty-three academic advisors took the time out of their busy schedules to complete the survey I sent them, and over a dozen faculty members gave me time to administer student surveys during their classes. I send each of them my heart-felt thanks.

Finally, I wish to thank my committee members. I want to thank Dr. Elizabeth Jones, my committee chair, for her careful reading and critique of each draft. She had a way of zeroing in on the key points of my thesis that needed revisions. My final product is better because of her. To Dr. Richard Hartnett I offer sincere thanks for challenging me to find the necessary confidence to speak up for my beliefs. He played devil's advocate when I first introduced the idea of creating an attitude scale and thereby helped me clarify a concept that was still hazy in my mind. Dr. Ernest Goeres, Ernie, put a human face on the doctoral degree process. He made sure that I didn't meet with any surprises, and guided me in the right direction at each step. I want to thank Dr. Andy Katayama for beginning the journey with me, and Dr. Richard Walls for stepping in when Andy moved away. Dr. Walls taught me a great deal about the appropriate statistics to use with my data and research through the Socratic questioning method. His nonthreatening approach filled me with the excitement of meeting a new challenge and gave me the confidence to surmount that challenge. My sincere gratitude goes to Dr. Neal Shambaugh who came to my rescue when an emergency prevented one of my committee members from attending my Oral Defense. With less than five hours' notice, Dr. Shambaugh generously set aside other responsibilities in order to read my dissertation and stand in for his colleague at the defense meeting. And finally, I wish to thank Dr. Hall, the Vice President of Instructional Affairs at my home institution. As I said, Dr. Hall has been one of my strongest professional supporters. He helped me through the process and gave me permission to conduct research at "home." 


\section{Table of Contents}

\begin{tabular}{lr}
\hline Abstract & ii \\
\hline Dedication & iii \\
\hline Acknowledgments & iv \\
\hline Table of Contents & vii \\
\hline List of Tables & x \\
\hline List of Figures & xi \\
\hline Chapter One: & 1 \\
\hline Introduction and Problem Statement & 1 \\
\hline Pre-Enrollment Academic Advising & 2 \\
\hline Attitudes Toward Developmental Coursework & 3 \\
\hline Problem Statement & 4 \\
\hline Research Questions & 5 \\
\hline Organization of the Dissertation & 5 \\
\hline Chapter Two: & 7 \\
\hline Review of Literature & 8 \\
\hline Mandatory Basic Skills Assessment and Placement in Developmental Coursework & 10 \\
\hline The Professional Defensibility of Mandatory Assessment and Placement & 12 \\
\hline Validation of Placement Systems & 14 \\
\hline Use of Decision Theory in Validating Placement Decisions & 16 \\
\hline Accuracy of Placement Decisions & 17 \\
\hline Pre-Enrollment Advising & 20 \\
\hline Placement Advising & 22 \\
\hline Attitudes Toward Developmental Education & 23 \\
\hline Attitudes Toward Underprepared Students & 27 \\
\hline Attitudes Toward Developmental Placement Policy & 30 \\
\hline Access versus excellence & 31 \\
\hline Laissez-faire versus structured open access & 32 \\
\hline Mandatory placement and academic excellence & 34 \\
\hline Effect of Attitude on Student Performance & 35 \\
\hline Prescriptive Versus Developmental Advising & 37 \\
\hline Definition of Key Terms and Concepts & 40 \\
\hline Chapter Three: & 41 \\
\hline Research Design & 41 \\
\hline Method & 41 \\
\hline Site Selection & 43 \\
\hline Sampling Procedure & 43 \\
\hline Strategy for Attaining Institutional Approval and Participant Cooperation & 44 \\
\hline Data Collection Instruments and Assurance of Data Trustworthiness & 47 \\
\hline Description of the Advisor Attitude Survey & 48 \\
\hline Description of the Student Advising Questionnaire & 52 \\
\hline Panel of Experts & \\
\hline The Pilot Tests & \\
\hline
\end{tabular}




\begin{tabular}{|c|c|}
\hline Data Collection Procedures & 55 \\
\hline Characteristics of the Two Samples & 58 \\
\hline Data Analysis & 60 \\
\hline Limitations of the Study & 64 \\
\hline Researcher’s Background & 65 \\
\hline Research Timeframe & 66 \\
\hline \multicolumn{2}{|l|}{ Chapter 4: } \\
\hline Results & 67 \\
\hline $\begin{array}{l}\text { Research Question 1: Is there a statistically significant relationship between } \\
\text { advisors' attitudes toward developmental placement and the type of advising } \\
\text { activities they perform? }\end{array}$ & 67 \\
\hline $\begin{array}{l}\text { Research Question 2a: Is there a statistically significant relationship between } \\
\text { advisors' attitudes toward developmental placement and the first-semester } \\
\text { academic performance of their advisees? }\end{array}$ & 68 \\
\hline $\begin{array}{l}\text { Research Question 2b: Do selected student factors account for variations in } \\
\text { student performance? }\end{array}$ & 71 \\
\hline $\begin{array}{l}\text { Research Question 3: Is there a statistically significant relationship between } \\
\text { advisors' attitudes toward developmental placement and advisees' perception } \\
\text { of their advisors' attitudes? }\end{array}$ & 74 \\
\hline $\begin{array}{l}\text { Research Question 4a: Which advising activities do advisees perceive as being } \\
\text { helpful? }\end{array}$ & 75 \\
\hline $\begin{array}{l}\text { Research Question 4b: In what ways, if any, do advisees believe that the } \\
\text { attitudes, words, and/or behaviors of their advisor influenced their own } \\
\text { progress and success? }\end{array}$ & 82 \\
\hline \multicolumn{2}{|l|}{ Chapter 5: } \\
\hline Discussion and Recommendations & 86 \\
\hline $\mathrm{H}_{1}$ : Relationship between Attitude and Activity & 86 \\
\hline Contribution to the literature & 89 \\
\hline $\begin{array}{l}\mathrm{H}_{2} \text { : Relationship between Advisors’ Attitudes and Students’ Performance and } \\
\text { Success }\end{array}$ & 90 \\
\hline Recommendations for Further Study & 93 \\
\hline Student Perceptions of Advisors' Attitudes and Activity & 93 \\
\hline Student Attitudes toward Developmental Placement & 94 \\
\hline Advisors’ Attitudes & 96 \\
\hline Attitude Surveys & 96 \\
\hline Recommendations for Practice & 96 \\
\hline Student Services Administrators & 97 \\
\hline Placement Assessment Office & 99 \\
\hline Those Who Organize Professional Development for Advisors & 100 \\
\hline Academic Advisors & 101 \\
\hline References & 102 \\
\hline $\begin{array}{l}\text { Appendix A: Letter to Vice President of Instructional Affairs Seeking Approval to } \\
\text { Conduct Research }\end{array}$ & 114 \\
\hline Appendix B: Letter of Approval from the Vice President of Instructional Affairs & 115 \\
\hline Appendix C: Cover Letter and Follow-up Letter to the Advisor Attitude Survey & 116 \\
\hline
\end{tabular}


Appendix D: Script/Cover Letter for Introducing and Administering the Student Advising 118 Questionnaire

Appendix E: Cover Letter to Faculty for Administering the Student Advising 119 Questionnaire

Appendix F: Advisor Attitude Survey 120

Appendix G: Item Categorization Matrix for Part 1 of the Advisor Attitude Survey Appendix H: Item Categorization Matrix for Part 2 of the Advisor Attitude Survey 124 Appendix I: Student Advising Questionnaire 125 Appendix J: Item Categorization Matrix for Parts 2, 3, \& 4 of the Student Advising 126 Questionnaire Appendix k: Item Categorization Matrix for Part 5 of the Student Advising Questionnaire 131 Appendix L: Follow-up Questions for AAS and SAQ Participants 132 133 


\section{List of Tables}

Table 1: Sawyer's Events Associated with identifying Academically Underprepared Students

Table 2: Number of Students Needing Remediation in the Three Developmental Disciplines

Table 3: Grade Distributions 60

Table 4: Correlations between Attitude and Advising Activity 68

Table 5: Correlations between Advisors' Attitude Scores and Student Performance 69 Indicators

Table 6: Correlations between Attitude Scores and Performance with Averaged Student 70 Data

Table 7: Correlations Among Student Performance Variables 71

Table 8: Correlations between Students' Perceptions and Advisors’ Attitudes

Table 9: Perceived Helpfulness Ratings for Advising Activities 74

Table 10: Students' Perceptions of Advisors' Influence on Performance 76

Table 11: Range and Frequency of Advisors' Scores on Three Attitude Scales 82

Table 12: Range and Frequency of Advisors' Scores on the Advising Activity Scale

89




\section{List of Figures}

Figure 1: Possible Course Placement Decisions 18

Figure 2: Link to Tinto’s Longitudinal Model of Departure $\quad 21$

Figure 3: Hypothesized Influence of Advisors’ Attitudes Toward Developmental 24

Placement on the Persistence and Academic Performance of Underprepared Students

Figure 4: Continuums Representing Two Subcategories of Attitude 46

Figure 5: Continuum Representing Advising Activity 47

Figure 6: Frequency of Advisors’ Attitude Scores in Matched Pair Data Set 91

Figure 7: Frequencies of Students’ Perceptions of Advisors’ Attitude Scores 92

Figure 8: Frequency of Advisors’ Attitude Scores When Each Score Counts Once 92

Figure 9: Frequency of Students’ Attitude Scores 95 


\section{Chapter One:}

\section{Introduction and Problem Statement}

Student retention is a critical concern at community colleges; due to open admissions policies, many students who enroll are not academically prepared to succeed. As a result, over fifty percent of students at public community colleges typically withdraw or fail out during their first or second semester of enrollment (McCabe, 2000). As King (1993a) points out, “On most two-year college campuses, underpreparedness is the norm, not the exception. Consequently, placement testing, followed by advising and appropriate course placement, is critical to student success and retention” (p. 26).

Two interrelated strands of research have made significant contributions to practitioners’ understanding of how both placement assessment and pre-enrollment advising are related to student retention and success. Research originating from the academic services branch of higher education and from the field of developmental education has shown persuasively that mandatory basic skills assessment and mandatory placement in developmental classes have a significant impact on student retention and success (Amey \& Long, 1998; Hadden, 2000; Roueche \& Roueche, 1999a). Underprepared students benefit from prescribed developmental courses. They are less likely to drop out and have significantly higher grade point averages than at-risk students who do not take the refresher courses (Roueche \& Roueche, 1999a; Rounds \& Anderson, 1985). Similarly, literature originating from the student services branch of higher education abounds with evidence that advising plays a key role in the success and retention of atrisk students (King, 1993a, 1993b; Morante, 1989, 2001). King (1993a) asserts,

First-generation college students, racial minorities, students needing remediation, and commuting students each possess characteristics that have been linked to higher college 
attrition. Consequently, two-year colleges need strong support services to help students remain in the institutions and achieve their goals. Academic advising is perhaps the most critical of those services. (p. 21)

Thus, community colleges have a responsibility to integrate assessment and advising services in order to ensure that students enroll in courses that match their skill and ability levels (Garing, 1993; Morante, 2001).

\section{Pre-Enrollment Academic Advising}

Even though advisors serve many functions throughout a student’s college career, the literature provides specific direction for actions that affect student retention when taken early in the advising relationship. Garing (1993) suggests four steps to be taken during initial advising appointments:

Specifically, advisers, first, must receive assessment scores for all of their advisees.... Second, advisers must understand the implications of the assessment results for their advisees' intended program of study. Third, they must communicate the institution's options regarding assessment to students who may not agree with the assessment results.... Fourth, advisors must sensitively address their advisees' questions and concerns about the assessment results; this sensitivity is critical when advisers must confront their students with the fact that the goal of building their skills through enrollment in remedial courses will require an additional semester or summer of coursework. (pp. 98-99)

Garing's suggestions, typical of those found in the literature, highlight the crucial role faculty advisors play in helping students understand the demands of college level work, and the reference to use of sensitivity in addressing advisees' concerns highlights the importance of 
advisors’ attitudes in their work with students.

\section{Attitudes Toward Developmental Coursework}

Even though research shows the benefits of mandatory assessment and placement, not all faculty advisors support such policies. For instance, some faculty are against mandatory testing and placement because they believe that students have the right to fail, others fear that students won't attend the college if assessment and placement in developmental courses is required, and still others believe that placement testing and developmental coursework are burdensome to students in terms of time and money (Morante, 1989).

Likewise, many students resent being placed into developmental courses. According to Sanford-Harris (1993),

It may be difficult for some students to understand or accept the fact that developmental courses may be required before they can register for courses that count toward the degree. Students may resent the institution for pointing out such shortcomings or may be embarrassed at their lack of college-level skills. Many will be concerned that enrollment in developmental courses will only delay them further in achieving their transfer or career goals and will resist adviser recommendations, insisting that "things are different now" and "I can do it." (p. 76)

Therefore, when students show reluctance to enroll in developmental courses, an important role of the advisor is to help them understand the importance of developmental prerequisites to success in college-level courses (King, 1993a; Sanford-Harris, 1993).

For some advisors, however, serving such a role is challenging. According to Morante (1989), "It is important to realize that the attitudes of faculty and staff and the resulting messages sent to students, direct or implied, will likely play a significant role in the success of any 
developmental education program including its testing and placement components” (p. 2). Given the critical nature of the advisor's role in initial course selection, an important question arises: Does an advisor's attitude toward developmental course work influence the way he or she behaves in the role of advisor and thereby impact the performance and persistence of underprepared students?

\section{Problem Statement}

Two concepts are clear in the literature: a) mandatory assessment and placement benefit underprepared students, and b) advisors play a key role in the retention and success of students. What is not clear from the literature is the precise role advisors' attitudes play in their initial contacts with underprepared students. Therefore, one purpose of this study was to explore whether there is a relationship between advisors' attitudes toward developmental placement and the subsequent academic performance and success of their advisees. Building on that foundation, the second purpose of this study was to explore the nature of the advisor/advisee relationship to determine what types of advisor activity influenced first semester performance and persistence. Two overarching hypotheses guided the study. The first hypothesis $\left(\mathrm{H}_{1}\right)$ was that advisors perform their advising duties in accordance with their attitudes or belief systems, or in other words, that advisors' attitudes are related to the type of advising activities they perform. The second $\left(\mathrm{H}_{2}\right)$ was that advisors' attitudes toward underprepared students and toward developmental placement policies are related to their advisees’ subsequent academic performance and perceived success. Research Question 1 relates to $\mathrm{H}_{1}$. Research Questions 2a, 2b, 3, 4a, and $4 \mathrm{~b}$ all relate to $\mathrm{H}_{2}$. Answers to the research questions will provide background data for adjusting advising policies, especially in regard to advising underprepared students, and redesigning the professional development system for advisors in order to maximize 
implementation of ideal pre-enrollment advising practices at community colleges.

\section{Research Questions}

1. Is there a statistically significant relationship between advisors' attitudes toward developmental placement and the types of advising activities they perform?

2a. Is there a statistically significant relationship between advisors’ attitudes toward developmental placement and the first-semester academic performance of their advisees?

2b. Do selected student factors account for variations in student performance?

- Student's attitude toward developmental placement

- Student's advisor's attitude toward developmental placement

- Number of days before or after classes begin that the student registers

- Number of credits the student registers for first semester

- Total number of developmental credits needed

- Age

- Which discipline or combination of disciplines of developmental coursework (math, reading, and/or English) are needed

- Gender

3. Is there a statistically significant relationship between advisors' attitudes toward developmental placement and advisees' perception of their advisors' attitudes?

4a. Which advising activities do advisee perceive as being helpful?

4b. In what ways, if any, do advisees believe that the attitudes, words, and/or behaviors of their advisor influenced their own progress and success?

\section{Organization of the Dissertation}

The remaining chapters of this dissertation consist of the review of the literature, the research design and method section, data analysis, and conclusions. The literature review, Chapter Two, is comprised of five major sections: the first develops a conceptual framework for 
understanding how the characteristics of underprepared, first-time college students affect retention rates; the second reviews research on how basic skills assessment, placement in developmental coursework, and pre-enrollment advising affect student performance and persistence; the third explores the literature on advisor and student attitudes toward developmental coursework; the next contrasts the prescriptive and developmental advising models and explores activities recommended by each model during pre-enrollment advising sessions; and the final defines key terms and concepts as revealed in the literature. Chapter Three describes and provides rationale for selecting the research design, as well as strengths and limitations of the study. It explains all methodological decisions for the study, including site selection, sampling procedure, strategy for attaining participant cooperation and institutional approval, data collection and analysis, assurance of data trustworthiness, the researcher’s background, and the research timeframe. Chapter Four details the data analysis procedures and reports the results. The final chapter interprets the results in light of current literature and discusses the implications for advising practice and future research. 


\section{Chapter Two:}

\section{Review of Literature}

Before exploring the relationship between advisors' attitude toward developmental placement and student performance, the background of several key issues must be explored. This literature review provides a conceptual framework for understanding how the unique characteristics of underprepared, first-time college students affect retention and success rates. It then reviews research on how basic skills assessment, placement in developmental coursework, and pre-enrollment advising all affect student performance and persistence. The next sections explore the literature on advisor and student attitudes toward developmental coursework, contrast the prescriptive and developmental advising models, and describe activities recommended by each model during pre-enrollment advising sessions. The final section defines key terms and concepts as revealed in the literature.

An important element of a community college's mission is to extend learning opportunities to students who might not otherwise gain access to higher education (Hays, 1994). Therefore, most community colleges have long struggled with the challenge of providing equitable access while maintaining academic excellence (Hadden, 2000; Rendon, 2000; Smittle, 1993; Utterback, 1998). Meeting that challenge demands an effective entry program that assesses students' basic skills, provides interpretation of assessment results, and places students into coursework in which they can reasonably be expected to succeed.

In order to determine whether learners are ready to enter the general college curriculum, over $90 \%$ of postsecondary institutions use some form of placement assessment and developmental instruction (Sawyer, 1996), with the percentage being even higher in community colleges (Roueche \& Roueche, 1999a). According to Robert McCabe (2000), approximately 
two-fifths (41\%) of entering community college students are underprepared in at least one of the basic skills. Recent studies have shown that of those who enter underprepared, only 40 to 50 percent successfully complete remediation (McCabe, 2000), resulting in a high rate of first-year attrition. Today's numbers are similar to those from a decade ago, when the 1992 American College Testing Survey estimated the first-year attrition rate for all entering students at public two-year institutions to be over 54 percent (Tinto, 1993).

Researchers have explored causes of first- and second-semester attrition, and practitioners have searched for effective first-year interventions that could increase retention, with much attention being focused on basic skills assessment, developmental placement, and academic advising. In order to diminish the startling rate of attrition, especially during the first year, research suggests that community colleges should implement mandatory basic skills assessment with a strong pre-enrollment advising component and mandatory placement into developmental courses for those with academic skill deficiencies. The literature also indicates that the advising needs to be conducted by caring individuals who embrace the developmental perspective in order to optimize the positive impact of these services (Herndon, Kaiser, \& Creamer, 1996; Lowe \& Toney, 2000; NACADA Council for the Advancement of Standards, 1997).

\section{Mandatory Basic Skills Assessment and Placement in Developmental Coursework}

Levitz and Noel (1989) found that academic underpreparedness is one of seven major forces of attrition. They report,

The nationwide decline in literacy rates makes underpreparedness a strong threat to retention; today's average high school graduate completes high school with better than a $B$ average and yet reads below the eighth-grade level. We often fail to assess basic skill 
levels and provide course placements that match the competency levels of individual students. (p. 69)

To combat this high rate of attrition caused by lack of preparation, many state community college systems "have begun to implement mandatory placement in developmental courses for those students institutionally defined as underprepared" (Amey \& Long, 1998, p. 3). Some evidence exists to suggest that students who take developmental courses by choice do better in those courses than do those who are forced (Utterback, 1998); however, most research indicates that mandatory basic skills assessment and mandatory placement in developmental courses for those who show deficiencies improve student retention and success (Amey \& Long, 1998; Anderson, 1985; Berger, 1997; Bernardi \& Castleberry, 1990; Cohen \& Brawer, 1996; Hadden, 2000; McCabe, 2000; Mitchell, 1998; Moore \& Carpenter, 1985; NADE Executive Board, 1998; Roueche \& Roueche, 1996, 1999a; Rounds \& Anderson, 1985; Shults, 2000; Smittle, 1993). In fact, the findings have been so compelling that in 1998 the National Association for Developmental Education's (NADE) Executive Board issued a resolution concerning the need for mandatory academic testing and placement of students in appropriate college courses: Whereas, academic assessment of all incoming students provides essential information for purposes of academic advising, career exploration, and enrollment into courses; Whereas, students' self-esteem and academic achievement is lowered when they are allowed to enroll in classes where they cannot succeed; Whereas, it is wasteful of tax dollars and of students' time and tuition dollars to enroll students in courses in which they have little chance of academic success; Therefore, be it resolved that the National Association for Developmental Education supports institutional policies that require mandatory academic assessment of incoming 
students and mandatory placement of students into developmental courses or services as appropriate. (para. 1-4; emphasis in the original)

On the basis of such endorsements and evidence from the extensive retention and success research, 75 percent of community colleges in the United States have adopted mandatory assessment and placement policies (Shults, 2000).

\section{The Professional Defensibility of Mandatory Skills Assessment and Developmental Placement}

Since on average over half of all first-time community college students require at least one developmental course, according to placement testing data (Roueche \& Roueche, 1999a), the issue of the appropriateness of mandatory placement testing and developmental coursework policy is vitally important at community colleges, and yet the issue is fraught with controversy. On the one hand, many practitioners believe that knowingly allowing students to register for courses for which they do not have the requisite skill borders on the unethical (Morante, 1989), but others believe that forcing students to expend time and money on developmental coursework that they may not need could be considered equally unethical.

Craig Hadden (2000), Dean of Instruction and Assessment at Lamar Community College in Colorado, highlights various facets of the issue that are common in the literature as he laments the ironies related to mandatory placement. On one side, he questions what is best for underprepared students by asking, "Is it ethical to deny any student access to a class? Is mandatory placement discriminatory, especially to minority students?” while at the same time wondering, "Is it ethical to allow underprepared students to fail?” (p. 824). He also explores the ethics of mandatory placement from the perspective of others who might be affected by the policy:

However, just as troubling is the issue of fairness to prepared students who may find 
themselves in classes in which the professor is moving at a slower rate or watering down the course material to help underprepared students pass the course. How ethical is it for faculty members trying to maintain academic rigor when half the class is underprepared to succeed? One might even wonder how ethical it is for taxpayers to pay for underprepared students to enroll in a course which they ultimately fail. (p. 824) Finding the optimum match between students' skill levels and course requirements through a placement program, then, becomes the responsibility for all open-door institutions. To meet that challenge, an ideal placement system would need to maximize the probability that students placed directly into credit-level courses are able to succeed without learning assistance and minimize the chance that students who do not need remediation are placed into developmental courses (Behrman, 2000).

Behind the dilemma surrounding mandatory testing and mandatory placement lie two seminal questions. With all that is known about the statistical margin of error involved in every form of testing, is it professionally defensible to prevent students from enrolling in college courses on the basis of one test score, and is it ethical to force students to enroll in a developmental course on the same basis? The simplistic answer to both questions, of course, is no. Utterback's (1998) solution, then, is to get rid of mandatory testing and placement. He asserts, "In view of the expense of academic assessment, validity issues, discriminatory factors, and the questionable value of developmental programs, colleges and universities should ask themselves what, if any, real value they get out of forced placement” (p. 52). Yet framed as an ethical issue, mandatory placement takes on greater significance and cannot be so easily dismissed. According to Frank (2000), the goal for academic advisors "in resolving an ethical dilemma is to find a balance where the least harm is done to everyone involved" (p. 45). 
In light of the benefits most experts in the field attribute to mandatory placement, therefore, another solution seems more feasible. Rather than eliminating assessment and placement, colleges should validate both their placement decisions and the value of their developmental coursework.

Validation of placement decisions isn’t simple. As Utterback (1998) points out, even though it is widely recognized that relying on a single test score is of little or no value, there remains a temptation to do so. The high reliability of the recently developed computer adaptive tests (Morante, 2001; Smittle, 1993) could lull those who use them into an unwarranted trust in the test results. Likewise, while many sources speak to the importance of providing students with high quality skills instruction, research has shown that skills taught in isolation do not necessarily transfer to other contexts. How, then, can colleges ensure that when students' skills improve, their performance in next-level courses also will improve? Hadden (2000) asserts, Unless community colleges take this step of defining entrance competencies and guaranteeing that developmental courses will help students achieve these competencies, they are opening themselves up to the arguments of those who believe that mandatory placement discriminates against students, particularly minorities. (p. 836)

Consequently, if community colleges are to adopt (or retain) the policy of mandatory assessment and developmental placement, as is the trend, they have an ethical imperative to validate their entire placement assessment systems.

\section{Validation of Placement Systems}

An effective assessment and placement system includes three main components working together: accurate prediction, appropriate advising and developmental instruction, and measurement of success in the standard course (Sawyer, 1996). In other words, once need for 
skill intervention is established through testing, underprepared students should have their scores interpreted by an advisor and be placed in developmental coursework that improves skills to the level necessary for success in standard college courses. After intervention, underprepared students should perform as well in the standard course as students originally qualified without intervention.

To address the validity of the first aspect of the placement system, accurate identification of those who need developmental instruction, the appropriateness of the cutoff score must be established. Most sources agree that an ideal cutoff score reliably distinguishes students who have adequate skills to succeed in college level courses (qualified students) from those who lack the skill to succeed without intervention (unqualified students) in order to make appropriate course placement decisions. However, Wamback and Brothen (1990) argue that this dichotomous grouping on the basis of test results is imperfect. They insist that students identified as being unqualified generally fall into three categories: false negatives (could succeed without intervention), underprepared students (could succeed if provided skill development intervention), and true negatives (cannot succeed even with intervention) (p. 14). Likewise, students identified as being qualified fall into two categories: false positives (would actually need intervention in order to succeed) and true positives (could succeed without intervention). Determining the validity of a particular cutoff score, then, would have to take into account the general preference of whether it is considered costlier to have incorrect placement decisions be the result of false negatives or false positives. Advisors who would rather risk their advisees' taking a college-level course for which they aren't adequately prepared on the chance that they could pass are more likely to support a lower cutoff score to protect against false negative decisions. Advisors who would rather risk their advisees' taking a developmental 
course to improve their skills even if they could possibly pass the college-level course without it are more likely to support a higher cutoff score to protect against false positive decisions. Therefore, establishing the validity of a placement cutoff score should take into account the various types of incorrect decisions, as well as the local opinion of the costliness of each type.

\section{Use of Decision Theory in Validating Placement Decisions}

Various theoretical approaches have been suggested for establishing the validity of placement assessment cutoff scores, including use of correlational studies (Gerow \& Murphy, 1980; Johnson, 1984), criterion models (Napoli \& Wortman, 1995; Wamback \& Brothen, 1990), and content-specific reading assessment (Behrman, 2000). The most promising approach, however, is use of decision theory with expected utility functions (Sawyer, 1996).

Decision theory models build upon the assumptions used with simple correlation methods and criterion models for establishing validity, but they incorporate a subjective element about the relative advantages and disadvantages of various decisions. According to Sawyer (1996), "by making additional assumptions about the costs and benefits of different actions and outcomes, one can also use observed statistical relationships to make inferences about the practical effectiveness of the placement variables” (p. 274).

In order to understand decision theory, one must first understand a simplified version of the possible outcomes associated with identifying academically underprepared students. If all students at a college were to take the placement assessment and then enroll in a standard college level course, there would be four possible events that could result for each student. Sawyer (1996, p. 276) summarized these possible events in a table (see Table 1).

If $K$ is the established cutoff score, then students scoring at or above $K$ would be considered qualified, or adequately prepared, for college level work, and those scoring below $K$ 
would be considered underprepared, or in need of instructional intervention. Events A and C Table 1: Sawyer's Events Associated with Identifying Academically Underprepared Students

\begin{tabular}{|c|c|c|c|}
\hline Event & $\begin{array}{c}\text { Test } \\
\text { score }\end{array}$ & Inference about student & $\begin{array}{c}\text { Performance in standard } \\
\text { course }\end{array}$ \\
\hline A & $\geq K$ & Adequately prepared & Successful \\
\hline B & $\geq K$ & Adequately prepared & Not successful \\
\hline C & $<K$ & Needs remedial instruction & Not successful \\
\hline D & $<K$ & Needs remedial instruction & Successful \\
\hline
\end{tabular}

represent accurate classifications of students, whereas Events B and D represent inaccurate classifications. Decisions (or predictions) based on the inaccurate classification of students, then, might be either false positive or false negative decisions. Event B represents a false positive result because, while the placement assessment indicates that a student is adequately prepared for a standard college level course, in reality the student is underprepared and does not succeed. Event D represents a false negative result because, while the placement assessment indicates that a student needs remedial instruction, in reality the student is adequately prepared and can succeed in the standard course without intervention.

The accuracy rate for a given cutoff score can be expressed as the relative frequency of correct classifications. However, judging the usefulness of a cutoff score with a simple accuracy rate ignores the different types of incorrect decisions (false negatives and false positives) and assumes equal cost for all inaccuracies. According to Sawyer (1996), “A function that expresses preferences among different pairs of outcomes and decisions is called a utility function...Such a function would quantify the different benefits of the two types of correct classifications and the different costs of the two types of incorrect classifications” (p. 276).

With decision theory, the utility of a given cutoff score is expressed through a formula that weights the various outcomes in a way that approximates preferences of stakeholders. For 
instance, Sawyer (1996) gives the following case scenario. "To a student who is willing to take risks, enrolling in and failing the standard course (Event B) might be more favorable than taking the remedial course when the student could have been successful in the standard course (Event D)” (p. 277). Since a utility function assigns a value, or weight, to the desirability of a decision that leads to a particular outcome, a utility function could be constructed for the above scenario that reflects a preference to minimize the time and cost required for passing courses by weighting the desirability of Event A as 1, Event C as 2/3, Event B as 1/3, and Event D as zero. In practice, using an expected utility function that approximates institutional preferences is a theoretically sound method of validating a placement cutoff score.

\section{Accuracy of Placement Decisions}

Placement decisions are made on the basis of an estimate of a student's skill proficiency (placement score) compared to an estimate of the skill proficiency necessary to succeed in a college level course (cutoff score). Since both the placement and cutoff scores are estimates, both scores have a margin of error. The combined margin of error of the two scores is of special concern to both advisors and students, especially when students score on the borderline between two different placement levels. Advisors' and students' level of confidence in placement recommendations will be discussed later in this review in the section on attitudes toward mandatory assessment and placement in developmental coursework.

A correct placement decision is made when a student's true skill proficiency matches the true level of proficiency necessary for success in the particular course in which the student enrolls. The two types of correct placement decisions are enrolling in a college level course when one's true skill proficiency meets or exceeds the true level of proficiency necessary to succeed in that course or enrolling in a developmental course when one's true skill proficiency is 
less than the true level necessary for success in a college level course. Incorrect placement decisions can also take two forms: enrolling in a college level course without possessing the true level of proficiency necessary to succeed or enrolling in a developmental course while possessing the true level of proficiency necessary for success in a college level course (see Figure 1).

In using assessment scores as the basis for deciding developmental or college level placement, decision theory quantifies institutional preference on a key question: Is it preferable to risk failing a college-level course by enrolling without possessing the true level of proficiency necessary to succeed, or is it preferable to risk taking a developmental course while possessing the true level of proficiency necessary to succeed in a college level course. An advisor's answer to this question is likely to influence the kinds of messages he or she gives to students concerning the relevance and importance of developmental coursework. Therefore, the advisor's attitude could affect students' attitude, which in turn could affect their performance.

\section{Pre-enrollment Advising}

Mandatory assessment and placement policies, though strongly supported in the literature, are not ends unto themselves. Imbedded in the NADE Executive Board's 1998 resolution is the proposition that academic assessment "provides essential information for purposes of academic advising, career exploration, and enrollment into courses” (para. 1). Therefore, a related strand of research highlights the importance of developmental academic advising in improving student retention and success. Many studies have found that effective use of the developmental model of advising leads to lower attrition rates and higher GPAs (Amey \& Long, 1998; Bohr, Cias, \& Clayton, 1973; Cohen, 1984; Forrest, 1985; Garing, 1993; Jesse \& Gregory, 1987; King, 1993a, 1993b, 1996; Levitz \& Noel, 1989; Lords, 2000; Mitchell, 1989; 


\section{Possible Course Placement Decisions}
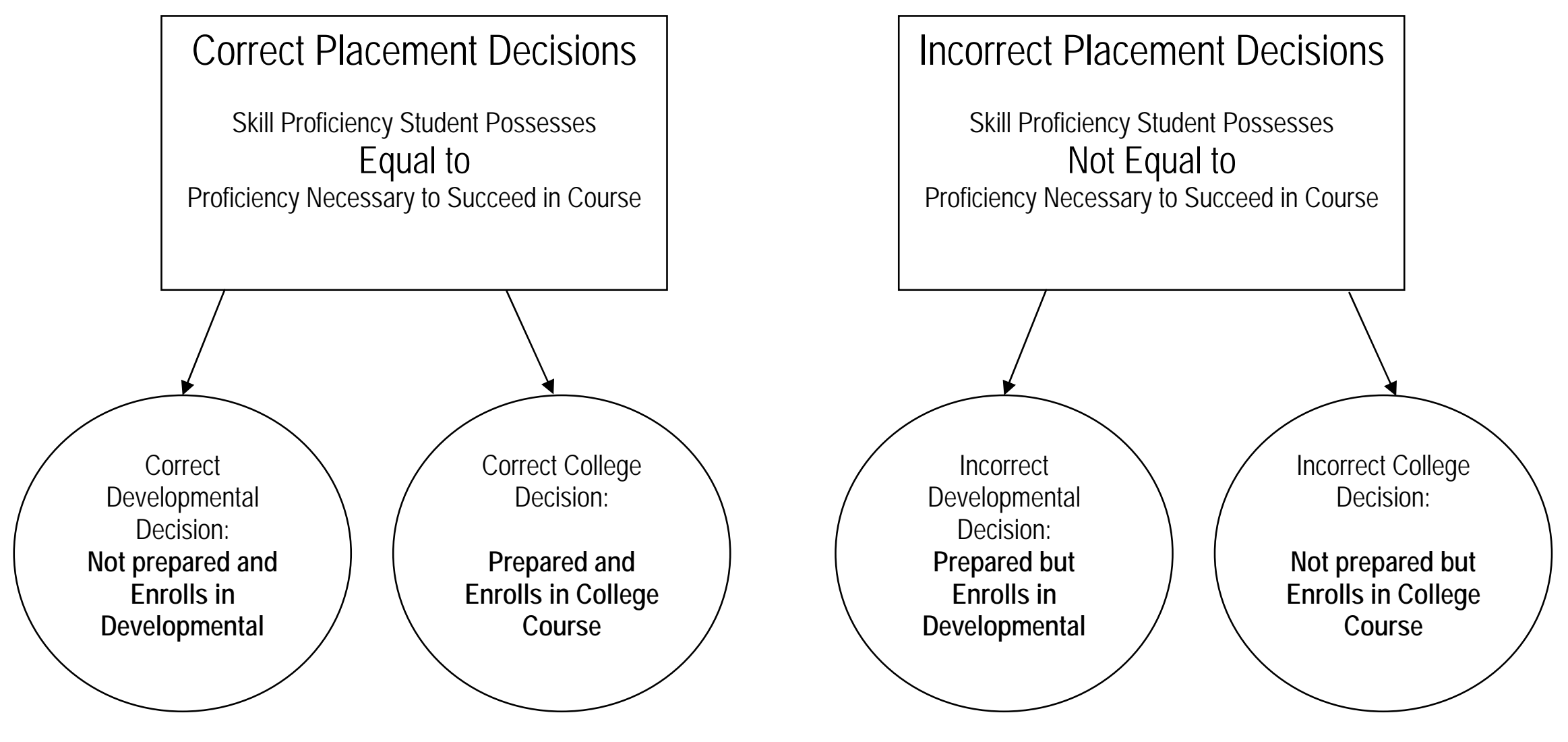

Figure 1: Placement recommendations are made on the basis of an estimate of a student's skill proficiency (placement score) compared to an estimate of the skill proficiency necessary to succeed in a college level course (cutoff score). Since both the placement and cutoff scores are estimates, both scores have a margin of error. A correct placement decision is made when a student's true skill proficiency matches the true level of proficiency necessary for success in the particular course in which the student enrolls. The two types of correct placement decisions are enrolling in a college level course when one's true skill proficiency meets or exceeds the true level of proficiency necessary to succeed in that course or enrolling in a developmental course when one's true skill proficiency is less than the true level necessary for success in a college level course. Incorrect placement decisions can also take two forms: enrolling in a college level course without possessing the true level of proficiency necessary to succeed or enrolling in a developmental course while possessing the true level of proficiency necessary for success in a college level course. Attitude toward developmental coursework is a rating of one's preference between the two forms of incorrect placement decisions: Is it preferable to risk failing a college-level course by enrolling without possessing the true level of proficiency necessary for success, or is it preferable to risk taking a developmental course while possessing the true level of proficiency necessary for success in a college level course. 
Morante, 1989, 2001). Developmental advising is "a systematic process to help students achieve educational, personal, and career goals" and is designed "to encourage and enhance intentional developmental change in students” (Herndon, Kaiser, \& Creamer, 1996, p. 637).

Advising is important throughout a student's college years, and effective academic advising programs "require structured intervention strategies at specified times from admission to graduation” (Garing, 1993, p. 97). Garing divides advising into two major time periods: inquiry to enrollment and enrollment to graduation. The importance of pre-enrollment advising can be demonstrated through various theories of human and student development. For instance, Tinto’s $(1987,1993)$ longitudinal model of institutional departure asserts that students come to college with particular pre-entry characteristics, such as basic skills and abilities, family background, and prior schooling. For underprepared students, pre-entry characteristics could include academic skill deficiencies, being the first in the family to go to college, and inadequate prior schooling that left huge gaps in background knowledge (Abraham \& Creech, 2000; Coley, 2000; Grimes \& David, 1999; King, M., 2002; Levitz \& Noel, 1989; Lundell \& Collins, 1999; Moore \& Carpenter, 1985; Pascarella, 1980; Roueche \& Rouech, 1999a; Sum, Kirsch, \& Taggart, 2002; Valverde, 1985). These pre-entry characteristics influence students’ goals, intentions, and commitments at entry, which in turn influence their subsequent integration into the academic and social systems of the college (Tinto, 1987, 1993). However, Margaret King, former president of the National Academic Advising Association (NACADA), points out that an effective advisor can help underprepared students understand the demands of college and develop appropriate strategies for attaining their goals while providing purposeful interaction with a caring individual faculty or staff member, thereby improving academic integration (1993a). Tenants of Tinto’s $(1987,1993)$ theory echo in King’s (1993a) assertions: “One can 
conclude, then, that strong developmental academic advising programs that promote student interaction with faculty and staff can greatly enhance a student's integration into the academic and social systems of the institution. That integration then contributes to student growth, satisfaction, and persistence” (p. 26) (see Figure 2).

\section{Placement Advising}

Another example of how student development theory demonstrates the importance of pre-enrollment advising is evident in research on collaborative efforts between a college's assessment and advising offices, specifically, with placement advising. Research shows that interpretation of assessment results is one of the most critical components of pre-enrollment advising (Fonte, 1997; Garing, 1993; Habley, 1993; King, 1993a, 1993b; McCabe, 2000; Mercer, 1995; Raushi, 1993; Shelor \& Bradley, 1999; Strommer, 1995; Utterback, 1998), and Randi Levitz and Lee Noel's (1989) seven forces of attrition provide the theoretical basis for explaining why.

According to Levitz and Noel (1989), studies of attrition indicate that students leave "because of a combination of complex, underlying factors—academic boredom, a sense of irrelevance, limited or unrealistic expectations of college, academic underpreparedness, transition difficulties, uncertainty about a major or a career, incompatibility” (p. 67). They have labeled those factors "forces of attrition," and several of the forces can be addressed during placement advising. Developmental advisors who have access to student assessment results can help the students develop "realistic expectations of themselves and of their college" (p. 68). They can also guide students into courses in accordance with students' basic skills, so that students are neither bored due to overpreparation nor overwhelmed due to skill or background knowledge deficiencies. While interpreting assessment results for students, advisors can also 


\section{Link to Tinto's Longitudinal Model of Departure}

(1) Pre-Entry

(2) Goals/Commitments

(3) Institutional Experiences

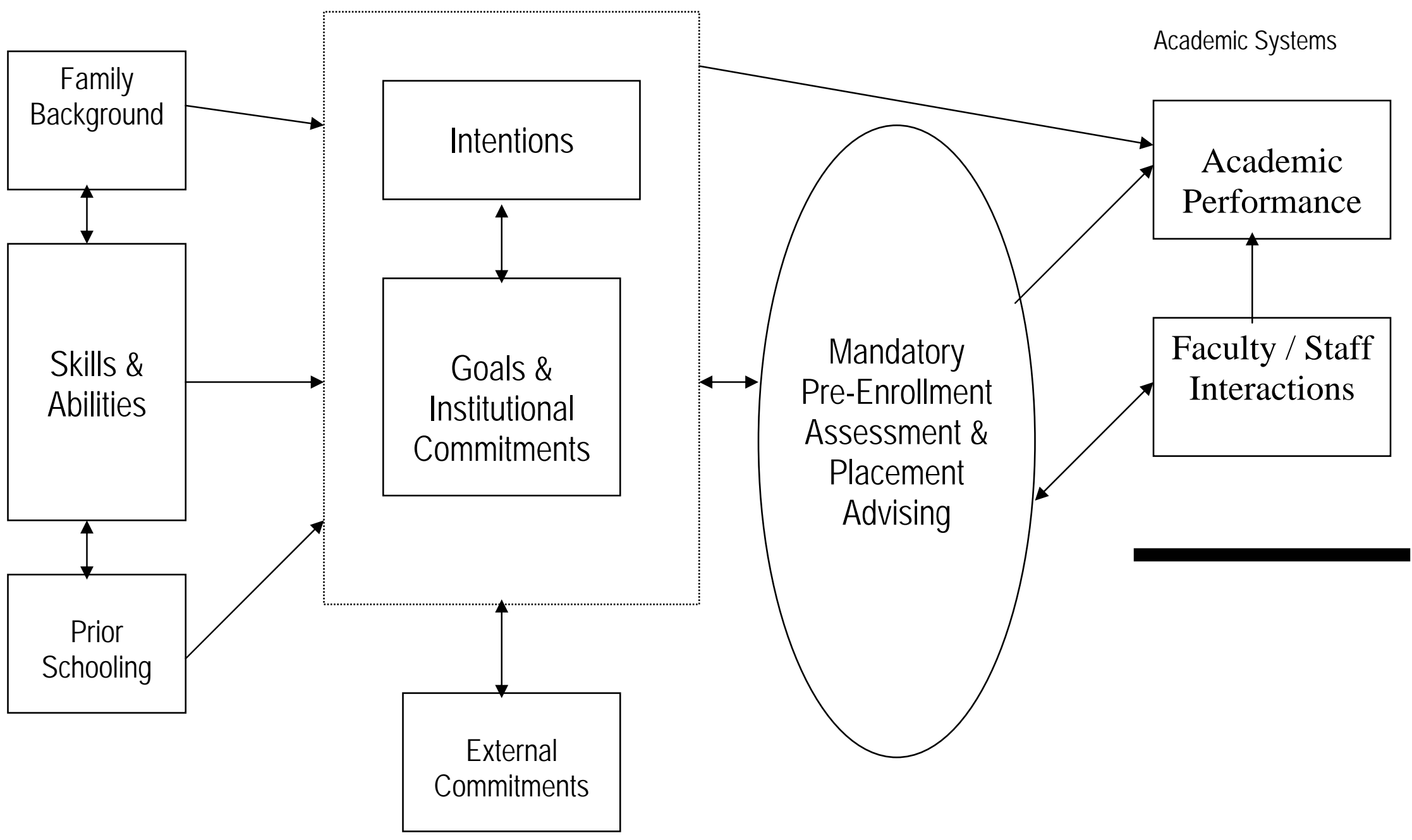

Figure 2: Portion of Tinto's (1987) Model of Institutional Departure modified with pre-enrollment intervention. 
combat a fourth major contributor to incidents of attrition, irrelevancy, by helping students see how their college work will be useful beyond the classroom. Levitz and Noel suggest, "Problems of irrelevancy develop because teachers and advisers neglect to interpret for students the benefits and usefulness of the college experience” (p. 68). Helping students understand the benefits and relevancy of courses that build prerequisite skill is especially important to combat attrition during the first or second semester.

\section{Attitudes Toward Developmental Education}

Though it has been established that the initial advising students receive can have a powerful impact on persistence and academic performance, Tinto (1993) states, "the effectiveness of such 'developmental advising' for student retention appears to reside...not only in the availability of such services, but in the manner in which they are presented” (p. 172). Levitz and Noel (1989) established through a retention study that "a caring attitude of faculty and staff is the most potent retention force on campus" (p. 66). According to Morante (1989), "It is important to realize that the attitudes of faculty and staff and the resulting messages sent to students, direct or implied, will likely play a significant role in the success of any developmental education program...” (p. 2). Imagine, for example, what kind of an attitude faculty advisors would project if they, as Spann, Spann, and Confer (1995) assert is the tendency, "perceive the underprepared student as not only underprepared but unsuitable for admittance to college. Rather than focusing on these students' strengths and potential, they focus on their deficiencies and often wonder what [they] are doing on a college campus” (p. 101). Clearly, advisors’ attitudes could influence their performance of advising duties during these pre-enrollment contacts with undergraduates and could thereby mitigate the positive effects. Yet research has convincingly shown that underprepared students benefit from prescribed remedial courses: they are less likely to drop out and have significantly higher grade point averages than at-risk students 
who do not take the refresher courses (Rada, 2000; Roueche \& Roueche, 1999a, 199b; Rounds \& Anderson, 1985). If faculty who advise students and who are responsible, at least in part, for enforcing mandatory placement requirements question the validity or effectiveness of the placement program or developmental coursework, then the messages they send to students could influence levels of compliance with policy as well as the overall impact on student persistence and performance (see Figure 3).

In the remainder of this section, attitudes will be examined along two distinct yet interrelated continuums. The first concerns how professionals view the individuals they serve; those on one end view underprepared students from a traditional frame, as being deficient and in need of remediation, while those on the other end view students from an interactional perspective, as being ill-suited to the environment and in need of academic and social integration. The second attitudinal continuum concerns open admissions to college and developmental placement policies; it contrasts the laissez faire view of open access, which favors optional developmental placement, with structured open access, which endorses mandatory placement.

\section{Attitudes Toward Underprepared Students}

Before examining attitudes toward developmental placement at the policy level, let us first examine the existing attitudes toward the population of students those policies are designed to serve. In an article attacking the high cost of providing basic skills instruction to underprepared college students, Cloud (2002) states, “Nothing angers conservatives more than fiscal excess on behalf of the slothful, which is how they see remediation” (p. 60). Cloud's derogatory reference epitomizes the popular perception of students who are placed into developmental courses; there is great stigma attached to the need for remediation (Aune, 2000; Cohen \& Brawer, 1996; Colby \& Opp, 1987; Fielstein \& Bush, 1998; Grimes \& David, 1999; 


\section{Hypothesized Influence of Advisors' Attitudes Toward Developmental Placement}

on the Persistence and Academic Performance of Underprepared Students

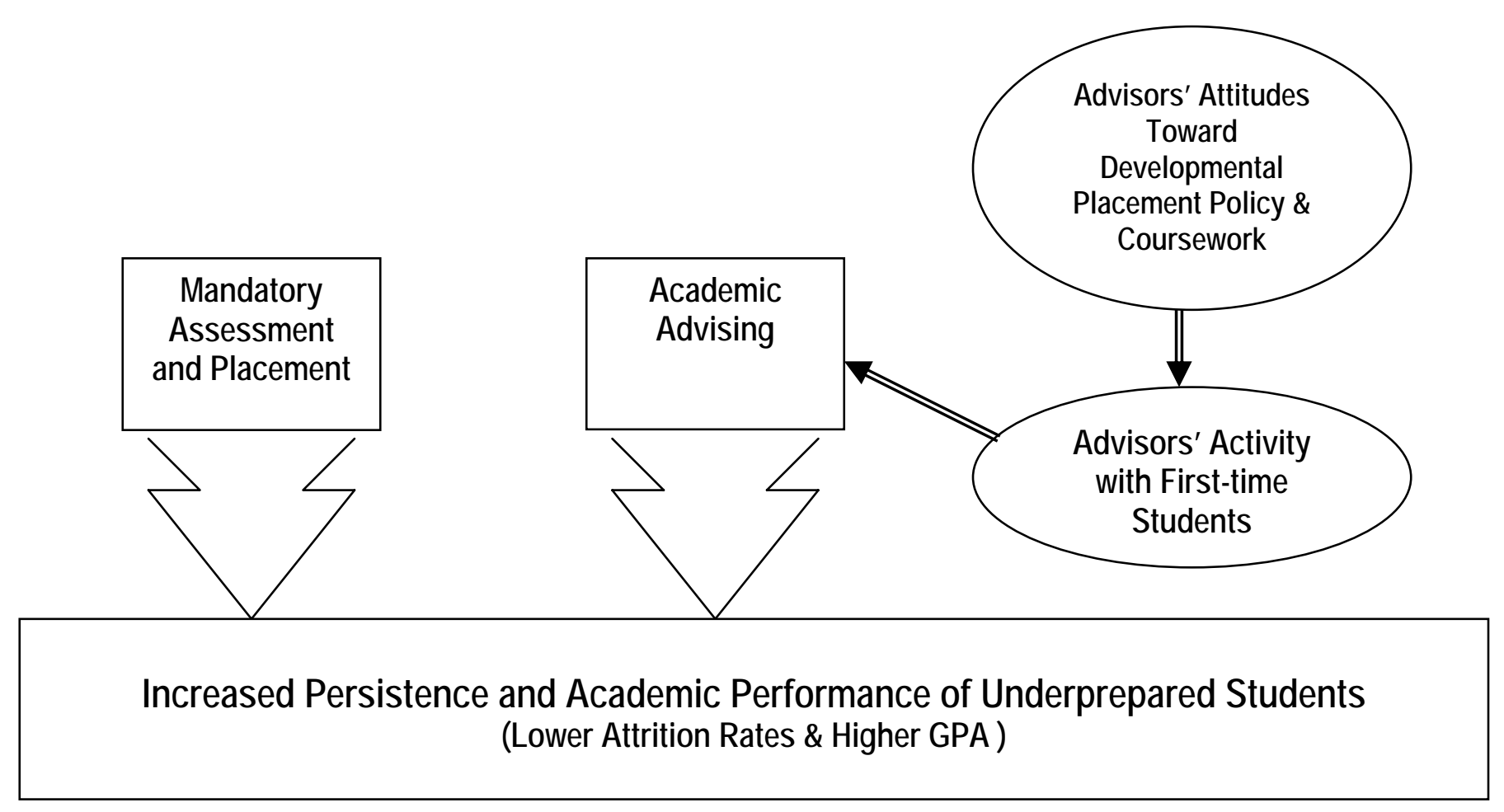

Figure 3. Key: Block arrows represent a direct causal relationship, as established through research. Small arrows represent the hypothesized relationships under investigation. 
Higbee, 1996; Ikenberry, 1999; Jones, Slate, Marini, \& DeWater, 1993; Mahon \&

Dannells,1998; Rhodes \& Valdez, 1996; Roueche \& Roueche, 1996; Spickelmier, 1973).

Ikenberry (1999) combats such characterizations of remedial students as "slothful” with a reminder: “...the current debate about remedial education incorrectly assumes that only students who failed to master high school work are enrolling in these courses. The fact is, students needing remediation are there for a variety of reasons” (p. 8). Yes, Ikenberry admits, some students who are unprepared to meet the academic demands of college goofed off in high school. However, nontraditional students returning to college after being out of school many years, students who graduated from poor high schools that did not provide adequate college preparatory classes, and students whose native language is not English, among others, might all require remediation; clearly they are in need for very different reasons, often for reasons beyond their control.

Even the ongoing debate over what to call basic skills classes provides evidence of a disparaging view toward underprepared students. Rouche and Rouche (1996) report that more than forty terms for such classes exist in the literature. They state, "Colleges have long wrestled with the titles for programs and courses that provide 'preparatory,' remedial,' or 'developmental' instruction in basic skills in an attempt to escape the history or the baggage or the negative connotations that are associated with such terms” (p. 77). Those who prefer the term “developmental” believe that "remedial” suggests a shortcoming, that students are deficient in some way and need to be fixed, whereas "developmental" implies that instruction is intended to aid development from whatever level of proficiency students possess to the level necessary for college success. Aune (2000) clearly explains the difference between these views. Although her discussion focuses on providing career and academic advising for students with disabilities, her 
explanation can be applied to all students who need remediation:

The traditional approach to disability has been from a medical (functional limitations) frame: something is wrong with the student, and the expert's job is to return the individual to "normalcy.” Normalcy, in the campus setting, has been accomplished by "remediating” the student to fit the campus environment. (p. 55)

She contrasts this traditional approach to the interactional (social constructivist) model, in which "the interaction between an individual and the environment determines whether a characteristic becomes a disability” (p. 55). The interactional view distinguishes between the biological fact of a disability and the handicapping social environment that interferes with a student's ability to succeed. The interactional model suggests, “....academic and social integration, not normalization, is what students need to be successful in college. Such integration requires just as much adjustment by nondisabled students, faculty, and staff as by students with disabilities” (p. 56).

The way advisors view underpreparedness, consciously or unconsciously, be it from a traditional or interactional perspective, is likely to influence both how they view their advising role and how they perform their advising duties. For instance, Broadbridge (1996) found that some advisors see their role as a peripheral part of the administrative function, while others view it as an integrated part of the educational process. Grimes and David (1999) found similar role uncertainty among faculty. They state, “...faculty may even express ambivalence toward the mission of helping at-risk students, suggesting that students are responsible for their own success or failure and attributing student weaknesses to deficiencies in character, mind, or social background” (Background section, para. 3).

Likewise, Aune (2000) suggests that if advisors view underprepared students as deficient, 
then they will likely operate in a prescriptive manner, whereas if they view underprepared students as needing to adjust to the college environment, they are more likely to operate in an accommodating manner. For instance, Levitz and Noel (1989) believe that advisors have the responsibility to help freshmen build appropriate expectations and develop the tools to meet them, yet they question, "If the faculty, staff members, and others on campus view this process as 'hand holding,' efforts to help freshmen make the adjustment will be undercut” (p. 73).

Aune (2000) urges career and academic advisors to recognize their own assumptions and how their assumptions affect their behavior: "Professionals need to examine whether they actually hold unfavorable or even hostile attitudes toward a particular group...It is important to emphasize that one’s practices must be examined as rigorously as one’s attitudes” (p. 58). In other words, advisors' attitude toward the people they advise could affect both the advisors' conception of what kind of support their students need and also the manner in which they carry out advising duties.

\section{Attitudes Toward Developmental Placement Policy}

The controversy over basic skills instruction for college students has expanded from strictly academic circles into the public arena, and developmental placement programs have come under attack by both the popular press and legislators. Grimes and David (1999) report, “Pressures generated from increasing numbers of underprepared students, decreasing financial resources, higher public expectations, and general negative public opinion have focused unprecedented attention on remedial college education and have sparked debates” (para. 6). Recently, Time magazine highlighted the debate in an article with the purposely-misspelled title, “Who’s Ready for Colege?” [sic] (Cloud, 2002). The author asks,

Should you be allowed into college if you don't read well enough to understand your 
local paper? What if you can't reliably write a complete sentence? ...When should the laudable goal of access for all yield to the equally important need to set standardsstandards that may exclude some? (p. 60)

The last question forces community colleges to set priorities in the access versus excellence debate, and many constituent groups, including taxpayers who spend close to one billion dollars per year on remedial coursework (p. 60), legislators, faculty, students, advisors, students' parents, and receiving transfer institutions, all have a stake in defining the answer.

Cloud (2000) claims that because the content taught in basic skills courses should, by definition, have been mastered by twelfth grade, "That means we pay twice to teach some people the rudiments” (p. 60). This view of remedial programs in college as an expensive duplication of services already paid for through the K-12 system is not uncommon (Grimes \& David, 1999).

Roueche and Roueche (1999b) respond to the arguments that mandatory assessment and placement are too expensive by urging colleges and the public to keep the costs of developmental education in perspective. They assert,

The actual cost of effective remedial education is small compared with the cost of maintaining a society with large numbers of uneducated, unemployed, unemployable, and disconnected citizens. Remedial programs can alleviate these ills and offer opportunities for citizens to become taxpayers, workers, and ultimately—consumers. Critics of remedial programs need data to compare the cost of education and training with the actual cost of alternatives—for example, inmate incarceration. (p. 15)

The expense of developmental education is not the only objection. Perhaps the more important objection concerns the impact of placement policy on open access. For instance, in a validity study of placement procedures at DeKalb Community College, Johnson (1984) reported, 
“Some faculty argued that the placement levels infringed upon the students' right to enroll in collegiate courses that, by virtue of the students' certified high school diploma, were readily available” (p. 10). Michell (1989) encountered similar objections to the enactment of mandatory placement policies. Opponents asserted that students had the right to fail and argued that open admissions institutions were obligated to grant open admissions to all courses; failure to do so, they argued, resulted in "penalizing, punishing, and otherwise discriminating against students who could take those same courses elsewhere” (p. 19).

Like others in the field (McMillan, 1993; Parnell, 1990), Hadden (2000) counters such arguments by suggesting that true access involves more than college admission; meaningful access involves becoming able to achieve defined educational objectives:

To provide the opportunity that education can afford in terms of increased income, better job skills, greater self-esteem, and all the other benefits inherent in a college education, we as educators must assume the responsibility of not giving students the choice of pursuing an educational track that we know dooms most of them to failure. Mandatory remediation and entrance requirements for courses temporarily deny students freedom so that one day they can be truly free. (pp. 833-834)

Although proponents of both arguments hold serving the best interest of students as the goal, they still disagree as to what is best. Do mandatory placement policies compromise the community college mission of open access by denying students the right to enroll in any course, or do mandatory policies protect the rights of those who are most at risk of failure by providing a structure within which they are more likely to succeed?

Even students enter the debate with strong views about placement policies, though their views are less often expressed in the literature. Advisors often report that students resent forced 
placement because it represents extra time, extra money, and credits that don't “count” for anything (Fielstein \& Bush, 1998; Garing, 1993; Sanford-Harris, 1993). Some students also experience self-doubt or the sting of embarrassment when placed in developmental classes, feeling stigmatized by their peers (Anderson, 1985). However, other advisors point out that students do not always understand the significance of placement results or the extent of the implications from enrolling in or bypassing developmental courses and therefore can't make an informed choice (Rhoades \& Valdez, 1996; Sanford-Harris, 1993). In such cases, the advisor needs "to help the student understand the importance of basic skills to success in college-level courses and may need to cite institutional statistics that show the success rate of students who successfully complete developmental courses versus those who do not” (Sanford-Harris, 1993, p. 78). Advisors can relieve students' objections by helping students realize that needing developmental courses is common and that the courses are meant to benefit rather than punish them (Sanford-Harris, 1993).

The emotion-laden language and vivid examples used by both sides in this debate over developmental placement policy point to a deep philosophical difference. While some stakeholders believe that mandatory basic skills assessment and placement in developmental courses are far too expensive and interfere with access, others believe that mandatory assessment and placement are cost-effective measures for making access more meaningful by encouraging high standards (Berger, 1997; Bernardi \& Castleberry, 1990; Fonte, 1997; Hadden, 2000; Hutchings \& Reuben, 1988; McMillan, 1993; Mitchell, 1989; Rendon, 2000; Rhodes \& Valdez, 1996; Roueche \& Roueche, 1999b; Utterback, 1998). Thus, the debate about placement policy is closely tied to the access versus excellence debate.

Access versus excellence. Access versus excellence has been at the heart of controversy 
in higher education for years (Smittle, 1993). The egalitarian ideal of open enrollment is intrinsic to the community college mission of providing educational access to all. At the same time, providing a quality education that prepares students for careers, transfer, and/or life-long learning and citizenship is also basic to the community college mission. Parnell (1990) describes the persistent tension between access and quality in economic terms:

Fail at the quality business and colleges will also fail to meet the competitive needs of our country. Fail at the business of access and America will fail to develop its most precious resource, the human resource. (p. 159)

While he maintains that access and quality are not mutually exclusive, Parnell also asserts, "they are not mutually supportive in program priorities, or resource allocation, or public understanding of the college identity" (p. 161). Thus, the tension persists.

Despite the intense debate, research has established that providing open access and high quality education are not necessarily polar opposites (Parnell, 1990). Both access and excellence can be achieved through an effective entry program that assesses students' basic skills and places them into appropriate coursework at the beginning of their college careers (Anderson, 1985; Smittle, 1993). Consequently, the ability for an open enrollment community college to maintain high standards is closely tied to its outlook toward developmental placement. Fonte (1997) explains, community colleges differ in the degree to which basic skills assessment and placement into developmental coursework are mandatory and universally applied, and these differences "frequently derive from conflicting philosophical outlooks" (p. 43). In other words, the access versus excellence debate is inexorably intertwined with attitudes toward developmental placement.

Laissez-faire versus structured open access. Fonte (1997) describes two different 
orientations toward open access to higher education, laissez-faire access versus structured access. In his typology, the laissez-faire open access viewpoint rejects restrictions placed on students that might limit their course-taking access or interfere with their right to choose. The structured open access perspective, on the other hand, endorses mandatory policies and proactive interventions that have been shown at other institutions to promote success. According to Fonte, Most community colleges can probably be placed on a continuum between these two approaches in their student success practices. Colleges that have few exemptions from a universal policy for all students would tend toward the structured open access model, and schools with many exemptions or only minimal application of mandatory prescriptions would be more laissez faire. (p. 45)

Likewise, advisors' perspective on the issue could also be placed on the continuum. Those who favor mandatory placement policies would tend toward the structured open access model, while those who believe that students have the right to sign up for any course, regardless of prerequisites, would be more laissez faire.

Mandatory placement and academic excellence. Many professionals, especially faculty, believe that the possibility of academic excellence is tied to whether a community college builds placement policy around a structured or a laissez-faire view of access. Palmer (1994) reports the range of faculty views toward the maintenance of academic standards in his review of twenty years of research on community college teachers' attitudes toward teaching and scholarship.

Several studies indicate that poorly prepared students contribute to faculty dissatisfaction with their jobs and faculty burnout (Palmer, 1994). If mandatory placement policies are not in place or are haphazardly applied, then the result can be a large proportion of students who do not have the prerequisite skill necessary to succeed in a particular class. Faculty often respond to the 
frustrating circumstances by lowering academic standards, slowing down instruction, or backing up and teaching skills or content that students should have possessed at entry (Hadden, 2000; Palmer, 1994). Palmer reported that one ethnographic study concluded that faculty tended to water down course reading and writing requirements in response to limited student literacy skills. Researchers found, “A subtle process of negotiation between students and teachers led faculty to stress mastery of isolated facts rather than synthesis and contextual knowledge” (Richardson, Fisk, \& Okum qtd. in Palmer, p. 428). Another researcher found that over time faculty came to accept low student academic ability and aptitude as inalterable. As a result of these perceptions, the faculty in Weis's year-long study at an urban community college

...gradually minimized their efforts in the classroom, decreasing the amount of course preparation time and relying on quizzes and short-answer tests. This, in turn, reinforced student behaviors that mitigate against academic achievement, further convincing faculty that their efforts to improve instructional practice and raise standards would have minimal results. (Palmer, 1994, p. 428)

Palmer's review of the literature also identified two additional factors related to underprepared students that can lead to a reduction of academic standards. First, faculty often expressed apprehension toward maintenance of high standards, fearing that ...insistence on challenging reading and writing requirements might isolate them from the college community, placing them at odds with administrators, who fear diminished enrollments; with students, who will register for other classes taught by less demanding instructors; and with faculty colleagues, who begrudge the perceived one-upmanship of those who cast their own instructional practices in a bad light. (Palmer, 1994, p. 428) Second, faced with students who are academically ill-equipped to succeed, caring faculty 
members often feel torn between maintaining high standards and helping these underprepared students obtain a degree that would improve their social and financial position. When mandatory basic skills assessment and developmental placement policies are not in place, all of these factors combine to create a climate where faculty have difficulty maintaining standards.

\section{Effect of Attitudes on Student Performance}

If faculty attitudes are affected by the number of underprepared students in their classes and as a result reduce the quality of their teaching, then what is the concomitant effect on adequately prepared students who enroll with the expectation or receiving a high quality education? Hadden (2000) argues that enforcing mandatory basic skills assessment and completion of developmental requirements is necessary in order to provide the best education for both academically agile and underprepared students. Hutchings and Reuben (1988) report that students both want and respond well to rigorous expectations from their teachers. In addition, Blustein and associates (1986) found a strong link between the attitudinal factor of students' expectations about their own learning and their actual academic performance.

What are the implications of attitudinal differences? Research has shown that faculty's attitudes affect how they teach and, by extension, what opportunities they give students to learn. Likewise, research suggests that students' attitudes and expectations affect how well they learn. Can we then hypothesize that advisors' attitudes affect how they advise and, then by extension, how students perform?

Little research exists to answer that question; however, the National Academic Advising Association suggests that advising practice does evolve from perceptions, values, and beliefs: Regardless of our professional preparation and experience, each of us in the field of academic advising is ultimately guided in our work by what we perceive as important, 
what we value, and what we believe about those we serve.... (NACADA, 1995, p. 174) There does appear to be a relationship between advisors’ attitudes and their advisees’ performance; further research is needed to explore whether the relationship is causal.

The previous section of this review focused on attitudes; it contrasted the traditional versus interactional perspectives toward underprepared students and the laissez faire versus structured open access outlooks toward policy. The following section will explore contrasting ways of translating those beliefs into action. The prescriptive and developmental models of advising represent two different paradigms, or belief systems, and as such, they represent two different ways of determining what constitutes appropriate advising activity. Those who favor the traditional view of individuals and a laissez-faire access view of policy are likely to favor the prescriptive (traditional) model of advising, while those who favor the interactional and structured access perspectives are more likely to favor the developmental model of advising.

\section{Prescriptive Versus Developmental Advising}

The prescriptive model of advising defines the advisor/advisee relationship in authoritative, single-directional, didactic terms (Broadbridge, 1996; Crookston, 1994; Herndon, Kaiser, \& Creamer, 1996; O’Banion, 1994a, 1994b; Winston \& Sandor, 1984). Viewing advising as just a peripheral part of the academic administrative function, this model limits advisor activity to providing information about courses, explaining registration procedures, and ensuring students enroll in appropriate courses, thereby permitting very little student control or decision-making power (Broadbridge, 1996).

In contrast, the main focus of the developmental model of advising is to encourage and enhance intentional developmental changes in students and to systematically involve students in the decision-making process (Herndon, Kaiser, \& Creamer, 1996). A developmental advisor 
engages students in conversations and information exchanges that assist the students in clarifying their career goals and educational plans, balancing the amount of challenge and structure they offer based on the students' developmental needs (Frost, 1994; King, 1996). Just as with prescriptive advising, developmental advisors need to provide accurate, up-to-date information to advisees; however, developmental advisors go further by helping advisees formulate and find answers to their own questions (Polson, 1994).

In the past twenty years, many researchers and practitioner have concurred that developmental advising is the most effective model for improving student retention (Crockett, 1985; Frost, 1990; Habley \& Morales, 1998; Herndon, Kasier, \& Creamer, 1996; Joseph, 2000; Levitz \& Noel, 1989; McAuliffe \& Strand, 1994; McCollum, 1998; Miller \& Alberts, 1994; Molina \& Abelman, 2000; O’Banion, 1994a, 1994b; Perry, 2001; Peterson \& McDonough, 1985; Polson, 1994; Raushi, 1993; Spiers, 2000). Moreover, most studies comparing student preferences on advising styles indicate that almost all students prefer or are more satisfied with developmental advising than prescriptive advising, and yet those same studies also point out that students are more likely to receive prescriptive advising (Baca, 1999; Belcheir, 1999; Herndon, Kaiser, \& Creamer, 1996; Neal, 1995; Polson, 1994; Spiers, 2000; Weston, 1994). System-wide practice of developmental advising, although widely touted, has yet to become the norm.

The National Academic Advising Association's Council for the Advancement of Standards states, “Academic advising is an essential element of a student's collegiate experience. It evolves from the institution's culture, values, and practices and is delivered in accordance with these factors” (NACADA, 1997, Role of Academic Advising, para. 1). Decision theory allows colleges to factor the general institutional preferences toward developmental placement policy (whether laissez-faire or structured) into the establishment of placement assessment cutoff 
scores. However, individuals, who may or may not agree with the policies, are responsible for interpreting placement results to students and helping students register for appropriate classes. This study tested the hypothesis that advisors' attitudes toward underprepared students and toward developmental placement policies are related to their advisees’ subsequent academic performance. Further, the study tested the hypothesis that advisors perform their advising duties in accordance with their belief systems. If they do, then knowing an advisor's attitude toward developmental students and toward developmental policy could be used to predict that advisor's activity with students.

\section{Definition of Key Terms and Concepts}

For the purposes of this study, the following definitions will be used.

Placement Score: An estimate of a student's current level of skill proficiency on COMPASS, a computer adaptive placement assessment instrument published by American College Testing (ACT).

Cutoff Score: A score on the COMPASS placement assessment set by the institution as an estimate of the level of skill proficiency necessary to succeed in a college-level course.

Course Placement Recommendation: The level of course (developmental or college) in which a student is eligible to enroll based upon his or her placement score. A placement score below the cutoff results in developmental course placement, and a placement score above the cutoff results in college course placement.

Correct Developmental Decision: When a student who is not adequately prepared for college level enrolls in a developmental course.

Correct College Decision: When a student who is adequately prepared for college level enrolls in a college course. 
Incorrect Developmental Decision: When a student who has the skill proficiency necessary to succeed in college level enrolls in a developmental course.

Incorrect College Decision: When a student who is not adequately prepared for college level enrolls in a college course.

Underprepared Students: Students institutionally defined as underprepared are students whose performance on the College placement assessment indicates the need for developmental coursework in at least one discipline (math, reading, and/or English).

Advisors: Faculty or professional staff members who sign the first semester advising grid of at least one underprepared student.

Advising Grid: The College’s official registration form, on which students indicate course selections and advisors indicate approval for enrollment in those courses with a signature.

Advisees/Students: Underprepared students with no previous college experience who enroll in college for the first time, whether part-time or full-time, during the Fall 2003 semester. The terms "advisee” and "student” will be used interchangeably throughout the text.

Advisor Attitudes: Advisors' self-ratings of their attitudes along two continuums, as reported on a researcher-constructed survey, the Advisor Attitude Survey: attitudes toward underprepared students (traditional versus interactional), and attitudes toward developmental placement policy (laissez-faire versus structured). Three scores on the Advisor Attitude Survey will be used as indicators of advisor attitudes: the Attitude Toward Underprepared Students score, the Attitude Toward Developmental Placement Policy score, and the Composite Attitude score.

Advisee Attitudes: Advisees' self-ratings of their attitudes along two continuums, as reported on a researcher-constructed survey, the Student Advising Questionnaire: attitudes toward 
underprepared students (traditional versus interactional), and attitudes toward developmental placement policy (laissez-faire versus structured). The composite rating will result in the Student's Attitude score.

Advisor Activity: Behaviors performed and explanations provided by an advisor during a preenrollment discussion with an advisee, such as explaining course prerequisites, conducting an informal assessment, showing a course syllabus or textbook, or guiding the student through a goal-setting worksheet. Two indicators of advisor activity will be used: advisors' self-report on the "Advising Activity" subset of questions on the Advisor Attitude Survey, and advisees' retrospective rating of their advisor on the "Awareness of Activity” subset of questions on the Student Advising Questionnaire.

Student Performance: First semester student performance will be measured with five indicators gathered through institutional records: a) overall first semester GPA; b) college-level course grades; c) developmental course grades; d) college-level course completion rates; and e) developmental course completion rates.

Student Perceptions: Advisees' rating of their advisor on three subsets of questions on the Student Advising Questionnaire, reported in three scores: Perception of Advisor's Attitude score; Perceived Influence on Performance score (of individual advising activities); and Perceived Helpfulness (of individual advising activities).

Student Success: Students' perceptions of their own academic performance.

Compliance: Enrollment in a developmental course when the placement assessment indicates a need for that course.

Non-Compliance: Enrollment in a college-level course when the placement assessment indicates a need for developmental coursework in the associated discipline. 


\section{Chapter Three: \\ Research Design}

This study explored, through a combination of methods, the degree to which advisors’ attitudes toward developmental placement are related to their advisees’ academic performance. The first three sets of research questions explored the relationships among variables "without any attempt to influence them” (Fraenkel \& Wallen, 2000, p. 359); therefore, the primary research design was correlational. Although both causal-comparative and correlational research methods explore relationships without manipulation of variables, correlational was the appropriate research design for this study because the variables under investigation were quantitative rather than categorical (Fraenkel \& Wallen, 2000).

A second research design, survey research, was used to study the fourth research question, which explored advisees' perceptions of whether or not, and in what ways, their advisors' attitudes and activities influenced their own academic performance. Like the first three sets of research questions, question four relied upon survey techniques to collect some of the data. The difference, however, was that questions one through three were primarily concerned with the relationships among various responses on the surveys, making the correlational research design appropriate. Research question four, on the other hand, focused on describing characteristics of the target population, so the overall design was that of survey research. The procedures for question four followed those suggested by Fraenkel and Wallen (2000): “Survey data are collected from a number of individual units of analysis to describe those units; these descriptions are then summarized to describe the population that the units of analysis represent" (p. 434). In this study, the unit of analysis was each individual advisee, and the target population 
was all first-time students institutionally defined as being underprepared at a public community college in the middle Atlantic region.

\section{Method}

\section{Site Selection}

The site for this study was a public, comprehensive, two-year college with three campuses located within a 50 mile radius of each other and all in rural, Appalachian communities. Mountainside Community College (fictitious name) has a total enrollment of approximately 3,600 students, including 2,400 on the main campus and 1,200 divided between the two branch campuses. Mountainside was selected as the research site because of the availability of indirect student data that would not be possible to obtain through unobtrusive measures at another institution.

\section{Sampling Procedure}

This study explored the relationship of the attitudes of academic advisors with the performance of first-time, underprepared community college students. The accessible student population was all Fall 2003 students at Mountainside Community College (MCC), part-time and full-time, who were attending college for the first time and whose scores on the COMPASS placement assessment (American College Testing Program, 2003) indicated the need for at least one developmental course in math, reading, or English. The advisor population was all Mountainside faculty and staff who provided the initial pre-enrollment academic advising to those students. An attempt was made to acquire data from each and every member of these two populations, with the exceptions described below.

To identify the student sample, the Office of Computer Services generated a list of all first-time Fall 2003 enrollees whose placement assessment scores indicated the need for at least 
one developmental course in math, reading, or English. Drawn from the entire population of students enrolled at MCC, the original list included 763 students enrolled as of the third week of classes. Fifty-seven students who were enrolled in classes taught by the researcher or who had been advised by the researcher or one of the MCC faculty members who participated in the pilot test of the Advisor Attitude Survey were excluded from the study to avoid possible conflict of interest or contamination of results. An additional 41 students who were enrolled only in offcampus courses (i.e., only a Web course or only an "Early College" course offered at a high school) were excluded because their experience with the advising process could have been significantly different from that of students who registered and attended classes at one of the three campuses. Therefore, the final research sample included 665 students $(\mathrm{N}=665)$.

All the professionals who potentially could have provided the initial pre-enrollment advising to at least one individual in the student sample constituted the advisor sample ( $\mathrm{N}=100)$. At MCC, new students do not always see their assigned advisor when registering for classes; rather, they often work with proxy advisors in the Admissions Office or within academic departments. Therefore, in order to determine who actually provided the initial pre-enrollment advising, the researcher manually inspected the advising grid of each student in the sample to determine who signed the grid. The person who signed the initial advising grid for each student, rather than the student's assigned advisor-of-record, was considered the advisor for all calculations in this study. This procedure provided an accurate indication of who actually helped the students enroll in classes. Student and advisor data were matched for statistical analysis, but confidentiality was maintained through a coding system that masked individual identity. 


\section{Strategy for Attaining Institutional Approval and Participant Cooperation}

The researcher gained approval to conduct the research at Mountainside Community College by sending a letter to the Vice President of Academic Affairs (see Appendix A for the letter of request and Appendix B for the letter granting approval). The request letter described the purpose of the study, the research methods, and the benefits the institution might expect in return for cooperation. The researcher gained cooperation from advisors at MCC by sending a cover letter out with the Advisor Attitude Survey (see Appendix C for cover letter and follow-up letter). The letter assured advisors that their responses would be kept confidential and explained how results of the research would benefit them and their students. Student cooperation was gained through one of two methods. The researcher personally administered the Student Advising Questionnaire to approximately 400 of the students during one of their developmental math, English, or reading classes. She explained the directions, the purpose, and the benefits of completing the questionnaire (see Appendix D for the script/cover letter used to introduce the $S A Q)$. Faculty members from the English, history, psychology, office technology, computer science, and automotive technology departments administered the questionnaire to approximately 265 students during one of their classes. For these students, the faculty member explained the purpose of the study (see Appendix E for the introductory script) and distributed the survey with a cover letter (Appendix D). Students completed the surveys and returned them to their instructor.

\section{Data Collection Instruments and Assurance of Data Trustworthiness}

Much has been written about how to perform academic advising with underprepared students, and researchers have used various surveys to measure the effectiveness of and student satisfaction with various advising activities. However, very little has been written about the role 
an advisor's attitude plays in academic advising. Therefore, the researcher constructed and then pilot-tested two new survey instruments to measure advisors’ attitudes toward developmental placement as well as advisees’ perceptions of their advisors’ attitudes. A two-part pilot study was conducted to gather evidence of each instrument's validity, clarity, and ease of use.

\section{Description of the Advisor Attitude Survey}

The first instrument, the Advisor Attitude Survey (AAS), was constructed to measure two constructs: advisors’ attitude toward developmental placement and types of advising activities practiced. In order to create an instrument with good content validity, current literature on academic advising for underprepared students was reviewed thoroughly (Aune, 2000; Belcheir, 2000; Billings, 2001; Bloom, 2002; Chenault, 1996; Creamer \& Creamer, 1994; Crockett, 1985; Culp, 1994; Ender \& Wilkie, 2000; Farren \& Vowell, 2000; Fielstein, 1994; Frost, 1990, 1991; Gardner, 1995; Garing, 1993; Gordon, 1984; Habley, 1993; Hadden, 1988; Hancock, 1996; Helfgot, 1995; Herndon et al., 1996; Jones et al., 1993; Jones, 1998; Jordan, 2000; Kadar, 2001; King, 1993a, 1993b, 1996, 2002; King, 2000; Kramer, 2000; Kramer \& Spencer, 1989; Laff, 1994; Levitz \& Noel, 1989; Lords, 2000; Lowe \& Toney, 2000; Marsh, 2000; Morante, 1989, 2001; NACADA, 1997; Onofrio, 1988; Peterson \& McDonough, 1985; Polson, 1994; Ramos, 1994; Rankey, 1994; Rhoads \& Valadez, 1996; Rooney, 1994; Roueche \& Roueche, 1996, 1999a, 1999b; Saluri, 1985; Sanders \& Wiseman, 2000; Sanford-Harris, 1993; Santa Rita, 1997;

Schein \& Laff, 1997; Severy, 1994; Stommer, 1995; Toy, 1985; White, 2000).

The literature concerning faculty and advisor attitudes focused on two distinct subcategories: attitudes held toward underprepared students and attitudes held toward basic skills assessment and developmental coursework policies. Therefore, two corresponding subcategories of survey items were created, with one portion of the survey items measuring 
attitudes along the continuum between traditional versus interactional views of underprepared students and another set measuring attitudes along the continuum of laissez-faire versus structured views of developmental placement policy (see Figure 4). Content validity of the instrument was enhanced by including statements or descriptions of underprepared students and developmental placement policy that appeared in the literature at least twice. Part 1 of the Advisor Attitude Survey (see Appendix F) includes eight items that represent attitudes at both ends of the traditional versus interactional continuum interspersed with twelve items that represent attitudes at both ends of the laissez-faire versus structured continuum (see Appendix G for an item categorization matrix for Part 1 of the AAS). Advisors are asked to rate their level of agreement with each statement in Part 1 on a four point Likert-type scale, with responses ranging from strongly agree to strongly disagree. Advisors' answers to the twenty questions in Part I result in two attitude subscores and a composite attitude score: "Attitude Toward Underprepared Students” (score range 8 to 32); “Attitude Toward Developmental Placement Policy” (score range 12 to 48); and "Composite Attitude" (score range 20 to 80, arrived at by summing the first two scores). The higher an advisor's composite and two subscale attitude scores, the closer that advisor's attitude is to the interactional and structured ends of the continuums described in Figure 4. In other words, the higher the scores, the closer an advisor is to holding attitudes favored in the literature.

In addition to measuring attitudes, a second use of the Advisor Attitude Survey was to determine what types of activities advisors practice and whether those activities are more consistent with the prescriptive advising model or developmental advising model (see Figure 5). Again, content validity was assured by gleaning advising activities that were recommended in the literature at least two times. Some activities on the survey are characteristic of the 
Figure 4: Continuums Representing Two Subcategories of Attitude

\section{RANGE OF ATTITUDES TOWARD UNDERPREPARED STUDENTS*

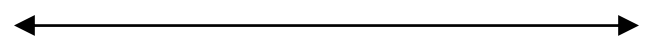

TRADITIONAL

* Medical model: Something is wrong and needs to be "fixed."

* Students are responsible for their own success or failure, and weaknesses are caused by deficiencies in character, mind, or social background.

* They are deficient and need to be "normalized" through remediation.

\section{INTERACTIONAL}

* Social constructivist model: There is a mismatch between the student and environment.

* Both students and school professionals are responsible for working together to make student success more likely.

* The student needs to be academically and socially integrated.

\section{RANGE OF ATTITUDES TOWARD DEVELOPMENTAL PLACEMENT POLICY**}

\section{LAISSEZ-FAIRE}

* Mandatory placement policies compromise the community college mission of open access by denying students the right to enroll in any course.

* Students have the "right to fail."

* Students should be allowed to enroll in any course, regardless of skill level.

* Prerequisites are suggestions, not requirements.

* If there were a question about placement, the advisor would encourage the student to take a college-level course and risk failing it rather than risk wasting time and money in a developmental course that wasn't truly necessary.

\section{STRUCTURED}

* Mandatory policies protect the rights of those who are most at risk of failure by providing a structure within which they are more likely to succeed.

* Students have the "right to succeed."

* Students should only be allowed to enroll in classes for which they possess the skills to succeed.

* Prerequisites are requirements that must be met, with few exceptions.

* If there were a question about placement, the advisor would encourage the student to take the developmental course to build skills, even if there was a chance he or she could pass the college-level course without it.

*Attitude toward underprepared students is measured on the Advisor Attitude Survey with items in Part 1: b, g-i, k-n, and also on the Student Advising Questionnaire with items in Part 2: c-j; Part 4: $c$ and d.

**Attitude toward developmental placement policy is measured on the Advisor Attitude Survey with items in Part 1: a, c-f, j, o-t, and also on the Student Advising Questionnaire with items in Part 2: a-b; all of Part 3; Part 4: a-b, e-g. 


\section{RANGE OF ADVISING ACTIVITY*}

\section{PRESCRIPTIVE}

* Advising is just a peripheral part of the academic administrative function.

* Advisor activity is limited to providing information about courses, explaining registration procedures, and ensuring that students enroll in appropriate courses.

- The advisor is the authority, and students have very little control or decision-making power.

* The advisor/advisee relationship is defined in authoritative, single-directional, didactic terms.

\section{DEVELOPMENTAL}

* Advising is an integral part of the teaching/learning process.

* Advisors not only provide accurate, up-todate information but also help advisees formulate and find answers to their own questions.

* Advisors encourage and enhance intentional developmental changes in students.

* Advisors systematically engage students in conversations and information exchanges that assist the students in clarifying their career goals and educational plans and purposefully involve students in the decisionmaking process.

*The degree to which advisors engage in developmental advising activity is measured on the Advisor Attitude Survey with all items in Part 2: a-dd, and is also measured on the Student Advising Questionnaire with all items in Part 5: a-w.

prescriptive advising model, and others are characteristic of the developmental model. Advisors are asked to rate on a four-point Likert-type scale the importance of performing each advising activity when registering first-time college students. Possible ratings include "Vitally Important,” "Helpful,” “Trivial,” or "Counterproductive.” The potential Advising Activity scores range from 30 to 120 (see Appendix $\mathrm{H}$ for an item categorization matrix for Part 2 of the AAS). The higher an advisor's Advising Activity score, the closer that advisor's activity is to the developmental end of the activity continuum described in Figure 5. In other words, the higher the score, the closer an advisor is to acting in accordance to the model favored in the literature.

\section{Description of the Student Advising Questionnaire}

The second survey instrument, the Student Advising Questionnaire (SAQ) (see Appendix I) was constructed to correspond in content to the Advisor Attitude Survey. However, since the 
intended respondents were underprepared college students, the $S A Q$ 's questions were worded in simpler language (approximately the eighth grade reading level) to avoid difficulty with readability.

Part 1 of the $S A Q$, which ascertains whether students remember who helped them register for classes, was not used for analysis in this research project but might prove useful for followup study. Part 2 asks students to rate the degree to which they think statements such as "I think my advisor thought the developmental courses would be good for me” represent their advisor's attitude. Parts 3 and 4 ask questions about students’ own attitude toward developmental placement. Part 5 asks students to indicate which activities their advisor performed and to what degree they found their advisors' words and activities helpful. Parts 6 asks students to indicate in what ways they believe that their advisor's activity influenced their performance in developmental and college-level classes. In addition, open-ended comments are encouraged. Student scores on the SAQ are calculated on three subscales: "Perception of Advisor's Attitude" (range 10 to 40 from questions in Part 2); “Student's Attitude” (range 8 to 32 from questions in Parts 3 \& 4); and “Student's Awareness of Activity” (range 0 to 23 from questions in Part 5). (See Appendixes J \& K for Item Categorization Matrixes for Parts 2 through 5 of the SAQ). Perception of the influence of advisors' attitudes and activities was not calculated for individual student participants. Rather, in order to summarize data across all participants, mean "Perceived Influence” item scores (range 1 to 4 for each item) were calculated for each statement in Parts 5 and 6 of the $S A Q$.

\section{Panel of Experts}

To enhance the content validity for both instruments, a panel of four experts critiqued the Advisor Attitude Survey and the Student Advising Questionnaire. The experts were asked to 
participate on the basis of their experience advising and working with underprepared students at the community college level. One expert was the director of advising at a community college in the same geographic region as Mountainside Community College (MCC). Another was the director of the developmental writing program at a different community college in the region. The other two were faculty advisors at MCC, one who advises career program students and the other who advises transfer students at MCC. The experts were asked to critique the constructrelated validity of the two surveys as well as the appropriateness of the scoring protocols.

The researcher handed out copies of Figures 4 and 5 and Appendixes A though K, which included charts depicting the theoretical perspectives under investigation, the survey cover letter and introductory script, the two surveys, and drafts of the survey item scoring protocols. The researcher then carefully explained to the expert panel the six major perspectives that survey items had been designed to measure, which included the traditional view of underprepared students, the interactional view of underprepared students, the laissez-faire view of placement policy, the structured view of placement policy, the prescriptive advising model, and the developmental advising model. Experts were asked to categorize each survey item according to which perspective they believed it most closely represents. Since the AAS and SAQ were created to correspond to each other in content, the experts concentrated first on critiquing the AAS and then suggested corresponding changes to the $S A Q$.

The panel raised questions about the researcher's categorization of five items on the AAS, stating that the scoring of one item in Part I and four items in Part II could be misleading. For instance, one expert pointed out that both an interactionalist and a traditionalist advisor might check that they strongly agree with the statement "My advisees just want to be told what courses to take," yet the two advisors could be interpreting the statement in opposite ways. That is, when 
traditional advisors refer to underprepared students as being passive, they might mean it as a negative comment; however, when interactionalist advisors refer to these students as passive, they might hold a concurrent expectation that it is an advisor's job to help the students take more control over their lives. The panel suggested new wording for this and similar survey items, but their phrases turned the original statements into advising model questions, and, since one of the research questions is whether advisors advise according to their attitude, the survey items need to separate attitude and actions. After thinking about whether to delete such statements or change their wording, the researcher decided to retain the statements until the pilot test to determine how pilot participants would react to the statements.

Some of the expert panel's concerns about ambiguous wording warranted immediate survey changes. For instance, the panel felt that survey responders might not automatically distinguish between placement scores and placement ranges or recommendations unless their attention is drawn to the difference. At the panel's suggestion, the researcher changed the following statement:

- Old: Knowing a student's placement scores is useful when advising.

- New: Knowing a student's specific scores as well as the placement recommendation is useful when advising.

Other changes to reduce ambiguity included specifying developmental prerequisites every time the word "prerequisites" is mentioned in the surveys and specifying discipline specific success in the three $A A S$ survey items that state, “Completing developmental [math (or writing, or reading)] requirements improves students’ chance for academic success” by adding a clarifying phrase to each:

- New: Completing developmental math requirements improves students’ chances for academic success in classes that require mathematical skill or reasoning. 
- New: Completing developmental writing requirements improves students' chances for academic success in classes that require much writing.

- New: Completing developmental reading requirements improves students' chances for academic success in classes that require heavy reading.

Two additional items were revised to improve clarity. Questions were raised about the meaning of the word "behind" in the statement, "Students who need to take developmental courses are behind," and about the meaning of the phrase "over their head" in the statement, "If students are over their heads in a class, it's up to them to find help.” One of the experts suggested changing the word "behind" to "deficient” because she felt respondents might interpret behind as a chronological fact rather than as a value judgment. The researcher decided to put the word "behind" in quotations to aid in interpretation. Likewise, she put the phrase "over their heads” in quotations to indicate the purposeful use of the cliché.

The last set of expert comments revolved around items that dealt with the time advisors spend with their advisees. One item questions the importance of working efficiently. Another questions the importance of spending less than ten minutes per advising session, and another of spending more than 30 minutes. The panel objected to the mention of a specific number of minutes, questioning whether advisors and students would remember the duration of their advising sessions. The researcher/survey author had chosen the times to represent very short sessions versus more in-depth sessions and did not intend the times to be taken literally. Therefore, she kept time-related questions in the survey to see how pilot participants responded to the questions.

Both surveys were revised according to the expert panel's suggestions. The same changes were made to corresponding items on each of the surveys. 


\section{The Pilot Tests}

After the expert panel critiqued the surveys, the revised versions of both instruments were then pilot tested. Three community college advisors took the Advisor Attitude Survey, and eight underprepared community college students took the Student Advising Questionnaire. The AAS pilot participants included three advisors. One advisor was from a regional community college that serves a student population similar to that of MCC. Another was a current MCC faculty member, and the last was a retired faculty member who had served as an advisor at MCC for over 30 years. After taking the AAS, participants discussed with the researcher their impressions concerning format, readability, clarity, and usefulness of the survey (see Appendix L to review the Follow-up Questions for AAS Pilot Participants). The participants' comments confirmed most suggestions made previously by the expert panel.

First, the researcher had left several items on the survey that the panel had questioned in order to see how pilot participants responded. Since all three pilot participants mentioned similar concerns about five of the items mentioned by the expert panel, one item from Part I and four items from Part II were deleted to assure legitimate scoring (see Appendixes G, H, J \& K for the resulting Item Analysis Matrixes):

- Deleted: Many of my advisees just want to be told what courses to take.

- Deleted: Tell students whether they have to take a developmental course.

- Deleted: Efficiently plan their semester schedule.

- Deleted: Tell them what courses to take.

- Deleted: Suggest that they retake the placement assessment to test out of their developmental courses.

Also based on both the expert panel and pilot study, the researcher revised or removed the wording of all items dealing with time taken during advising: 
- Old: Spend 30 minutes or more helping students plan out what to take the next few semesters.

- New: Spend approximately 30 minutes or more helping students plan out what to take the next few semesters.

- Deleted: Spend 10 minutes or less picking classes for the semester.

Pilot participants suggested additional changes to the survey. Three items were revised based on their feedback:

- Old: One of the most valuable tools I can offer my advisees is to help them learn to make informed decisions about what courses to take.

- New: Helping my students learn to make informed decisions about what courses to take is an important part of my role as advisor.

- Old: Explain why they need to take a developmental course.

- New: Explain to students why they need to take a developmental course.

- Old: Ask them questions about why they picked their major.

- New: Ask questions about why they picked their major.

In addition, two participants mentioned that the list of advising activities was intimidating

and made them feel like there was no way any advisor could complete all of those tasks in one session. Therefore, to improve clarity, the directions for part two of the AAS were revised:

- Old: Please rate the importance, in terms of the degree of influence it might have on students' success, of performing each of the following activities when registering firsttime college students.

- New: In terms of the degree of influence on student success, please rate the importance of performing each of the following activities in the limited time available for advising and registering first-time college students.

Finally, one participant suggested two more advising activities that are important, so those items were added to the survey:

- Added to Part I: I am knowledgeable about this college’s Academic Regulations. 
- Added to Part II: Explain general college procedures, such as how to get a library card or how to drop a course.

MCC’s “Academic Regulations” consists of a list of rules that govern all academic procedures, including developmental placement policy. For instance, Academic Regulation A.2.a states: “A degree applicant with no previous college experience and whose placement assessment scores indicate a need for improvement in one or more of the developmental academic areas will be placed in required developmental courses and will be limited to no more than 14 semester hours per semester until the deficiency is corrected....”

Unlike the numerous changes made to the $A A S$, only one change was made to the Student Advising Questionnaire after the pilot test. The SAQ pilot participants included eight students at Mountainside Community College who were enrolled in a developmental reading or English course during Summer Session, 2003. After taking the SAQ, participants discussed with the researcher their impressions concerning format, readability, clarity, and usefulness of the survey (see Appendix L to review the Follow-up Questions for SAQ Pilot Participants). Participants reported that the survey was easy for them to understand. They had no difficulty understanding item wording, and they knew where and how to mark their answers. However, three participants reported that they had not read the directions. They suggested that the researcher should read the directions out loud to participants when she administers the survey for the primary study. Therefore, the script introducing the $S A Q$ was revised to remind students of the importance of reading the directions to each section of the survey:

- Old: Please read each question carefully and answer based upon your own personal experience.

- New: Please read the directions to each section carefully, and then read each question carefully and answer based upon your own personal experience. 
As a result of the expert panel and pilot study, both the Advisor Attitude Survey and the Student Advising Questionnaire are stronger instruments. The feedback given by the expert panel resulted in significant changes in wording. Feedback from the pilot test participants confirmed the experts' assessments and resulted in minor additional changes. Since the two surveys were constructed in such a way as to correspond in content, when a change was made to one survey, a similar revision was made to the other. The feedback obtained from the expert panel and pilot tests indicated that the $A A S$ and $S A Q$ are likely to yield useful data.

\section{Data Collection Procedures}

Data collection began in October 2003 with distribution of the Advisor Attitude Survey. The researcher obtained a list of all advisors at the college and sent each one (except those who had participated in the AAS pilot test) a survey through campus mail with a cover letter and selfaddressed return envelope. The surveys were sent to 97 advisors, and 72 were returned within two weeks. The researcher sent a follow-up letter to non-respondents, which resulted in the return of eight additional surveys. It was later found when matching students with their advisors that three additional people had signed students’ advising grids. The researcher sent those individuals a survey in December, and all three completed them. Therefore, a total of 83 out of 100 AAS were returned.

The researcher began administering the Student Advising Questionnaire in late October. Surveys were coded, put into business envelopes with the students' names, and sorted for distribution according to developmental class sections. The researcher had planned to administer the survey personally to nearly the entire sample in one of the students' developmental classes, with a small number to be distributed in psychology classes for those who somehow bypassed the developmental requirements. Therefore, she made arrangements with all developmental 
faculty in order to gain access to the students in their classes. In over 30 classes, the researcher administered the survey and remained on hand to answer questions while students completed it. In four classes, due to time constraints of the course instructor, the researcher was only able to give the instructions and ask students to complete the survey at home and return it to their instructor the next day. If a student was absent the day the researcher administered the survey, that student was considered a non-respondent, and no further follow up was attempted. However, if a student had withdrawn from a particular class, then the researcher attempted to administer a survey to that student in a different class.

An unforeseen circumstance occurred in that almost half of the student sample was not enrolled in any developmental classes despite the fact that their placement scores indicated they should take these courses. Therefore, the researcher added a cover letter to the remaining student surveys, sorted them according to class rosters for college-level English, history, psychology, office technology, computer science, and automotive technology classes, and distributed the surveys to course instructors with the request that the faculty members administer the surveys (see Appendix E for letter to faculty with their script for introducing the SAQ). Many of the faculty members allowed their students class time to complete the surveys, but most asked the students to complete the surveys at home and return them the next day.

Of the 665 students in the research sample, 371 completed the $S A Q$, a return rate of 56\%. Over 250 of the returned surveys had been administered by the researcher in developmental classes, and the remainder had been distributed by other faculty members.

Once the completed advisor and student surveys had been returned, the process of matching student to advisor began. In order to determine who provided the initial pre-enrollment advising for the 371 students who had returned surveys, the researcher manually inspected the 
advising grid of each student to determine who signed the grid. The person who signed the initial advising grid for each student was considered the advisor for all calculations in this study.

In most cases, the students had met with only one advisor. However, in several instances, a student registered for classes on one date and then returned on a later date to drop or add a class or to change sections of a class. If the student made a schedule change only one time, even if the student met with a different advisor on the second visit, the first advisor — the one who registered the student for the primary schedule—-was recorded as the advisor. If the student went through the drop/add process more than once, however, that student was excluded from the study. In four cases, a student registered for a complete schedule with one advisor and then later changed majors and completely reregistered for a whole new schedule with a new advisor. In these four cases, the second advisor — the one who had registered the students in the classes that they took fall semester—was recorded as the advisor.

After the researcher had determined all student/advisor pairings, she found that some students had left questions blank or skipped entire sections when completing the Student Advising Questionnaire. A total of 360 student surveys were complete enough to use in at least some of the calculations. Of those usable student surveys, 317 were from students who had been advised by one of the advisors who had returned a survey, and 43 surveys were from students who had been advised by five non-responding advisors.

The final stage of data collection involved obtaining data from institutional records. The Office of Computer Services generated a report that included three different grade calculations for all students in the sample: average grade in developmental courses, average grade in collegelevel courses, and overall semester grade point average (GPA). The overall GPA used for calculations in this study included all grades, both developmental and college-level. 
The Office of Computer Services was not able to produce a report that included collegelevel course completion rates and developmental course completion rates. Therefore, the researcher obtained a copy of the target students' first semester transcripts and calculated these two student performance indicators by hand. Other student data (number of days before or after classes begin that the student registers, number of credits the student registers for first semester, total number of developmental credits needed, the student's age, which discipline or combination of disciplines of developmental coursework he or she needs, and the student's gender) were gleaned by hand from registration records.

\section{Characteristics of the Two Samples}

The 43 advisors used in the study ranged in experience advising at the college level from one year to 35 years. The average length of experience was $14.2(S D=9.9)$ years. Twenty-three (53\%) of the advisors were female and 20 (47\%) were male. Ten (23.3\%) of the advisors reported having taken at least one developmental course when they were in college.

The 360 students ranged in age from 16 to 58 with the mean age of $21.6(S D=7.1)$. Two hundred forty (68\%) students were female and 120 (32\%) were male. According to placement test results, the students' developmental requirements ranged from needing three to 19 credits of developmental coursework, with a mean of needing $8.39(S D=3.8)$ credits. One hundred seventy (47\%) students needed remediation in just one discipline, 103 (29\%) needed remediation in two disciplines, and 86 (24\%) needed remediation in all three (Table 2).

Students registered for between three and 21 credits during their first semester. The mean number of credits taken was 12 (SD 3.0), which at MCC constitutes a full time credit load. Two hundred ninety-two (81\%) students were enrolled full time, and 68 (19\%) were part time. 
Table 2: Number of Students Needing Remediation in the Three Developmental Disciplines

\begin{tabular}{|l|c|}
\hline Developmental Discipline(s) Needed & $\begin{array}{c}\text { Number of } \\
\text { Students } \\
(\%)\end{array}$ \\
\hline Math & 169 \\
$(47.1)$ \\
\hline Writing & 1 \\
& $(.3)$ \\
\hline Math \& Reading & 13 \\
Math \& Writing & $(3.6)$ \\
\hline Reading \& Writing & 89 \\
& $(24.8)$ \\
\hline Math, Reading, \& Writing & 1 \\
Missing Data & $(.3)$ \\
\hline & 86 \\
& $(24)$ \\
\hline
\end{tabular}

Students’ academic performance, as measured by Developmental, College, and Overall Grade Point Averages (see Table 3) and Developmental and College-Level Course Completion Rates, spanned the entire possible ranges of 0.0 to 4.0 for GPA and 0.0 to 1.0 for completion rates. The average developmental GPA was $2.5(S D=1.1)$, with over $80 \%(\mathrm{~N}=224)$ of the 279 students registered for developmental classes earning at least a 2.0. The average completion rate for developmental courses was $84 \%(S D=31)$. The average GPA in college-level classes was $2.7(S D=.9)$. Over $80 \%(\mathrm{~N}=285)$ of the 351 students registered for college-level classes earned at least a 2.0; the average completion rate for college-level courses was $87 \%(S D=27)$. Overall GPA was calculated by averaging all grades, both developmental and college-level. The average Overall GPA was $2.6(S D=.9)$, and almost $78 \%(\mathrm{~N}=279)$ of the 360 students in the study earned at least a 2.0. 
Table 3: Grade Distributions

\begin{tabular}{|l|c|c|c|c|c|}
\hline & $\begin{array}{c}\text { Mean } \\
\text { (Std. Dev.) }\end{array}$ & $\begin{array}{c}\text { Earned } \\
0.0 \text { to } 1.9\end{array}$ & $\begin{array}{c}\text { Earned } \\
2.0 \text { to } 2.9\end{array}$ & $\begin{array}{c}\text { Earned } \\
3.0 \text { to } 3.9\end{array}$ & $\begin{array}{c}\text { Earned } \\
4.0\end{array}$ \\
\hline $\begin{array}{l}\text { Developmental GPA } \\
(\mathrm{N}=279)^{*}\end{array}$ & $\begin{array}{c}2.5 \\
(1.1)\end{array}$ & $19.7 \%$ & $33.0 \%$ & $26.5 \%$ & $20.8 \%$ \\
\hline $\begin{array}{l}\text { College-Level GPA } \\
(\mathrm{N}=351)^{*}\end{array}$ & $\begin{array}{c}2.7 \\
(1.0)\end{array}$ & $18.8 \%$ & $32.8 \%$ & $31.6 \%$ & $16.8 \%$ \\
\hline $\begin{array}{l}\text { Overall GPA } \\
(\mathrm{N}=360)^{*}\end{array}$ & $\begin{array}{c}2.6 \\
(0.9)\end{array}$ & $22.3 \%$ & $33.3 \%$ & $33.5 \%$ & $10.9 \%$ \\
\hline
\end{tabular}

${ }^{\star}$ The total $\mathrm{N}$ used to calculate the three different GPA averages differs because although most students registered for both developmental and college-level classes, a few students enrolled in just one type or the other.

\section{Data Analysis}

Research Question 1 examined the relationship between an advisor's espoused theory and his or her theory in practice. Six correlational analyses were performed to find the relationship between each of the three indicators of advisor attitude (Advisor’s Attitude Toward Underprepared Students score, Advisor's Attitude Toward Developmental Placement Policy score, and Advisor's Composite Attitude score) with the two indicators of the degree to which they engage in developmental advising activity (Advisor's Advising Activity score and Student's Awareness of Activity score).

\section{Is there a statistically significant relationship between advisors' attitudes toward developmental placement and the type of advising activities they perform? (Six correlations with matched advisor/advisee data)}

\begin{tabular}{|c|c|}
\hline Advisors' Attitude & Advising Activity \\
\hline $\begin{array}{l}\text { - Advisor's Attitude Toward } \\
\text { Underprepared Students score on the AAS } \\
\text { (range } 8-32 \text { ) } \\
\text { - Advisor's Attitude Toward } \\
\text { Developmental Placement Policy score } \\
\text { on the AAS (range } 12-48 \text { ) } \\
\text { - Advisor's Composite Attitude score on } \\
\text { the } A A S \text { (range } 20-80 \text { ) }\end{array}$ & $\begin{array}{l}\text { - Advisor's Advising Activity score on the } \\
\text { AAS (range } 30-120 \text { ) } \\
\text { - Student's Awareness of Activity score on } \\
\text { the } S A Q \text { (range } 0-23 \text { ) }\end{array}$ \\
\hline
\end{tabular}

Research Question 2a sought the correlation between three continuous indicators of advisors’ attitudes (advisors’ Attitude Toward Underprepared Students scores, Attitude Toward Developmental Placement Policy scores, and Composite Attitude scores) with five indicators of 
student academic performance, also continuous variables (overall first semester GPA, collegelevel course grades, developmental course grades, college-level course completion rates, and developmental course completion rates).

\begin{tabular}{|c|c|}
\hline \multicolumn{2}{|c|}{$\begin{array}{l}\text { 2a. Is there a statistically significant relationship between advisors' attitudes toward } \\
\text { developmental placement and the first-semester academic performance of their } \\
\text { advisees? (Fifteen correlations using matched advisor/advisee data) }\end{array}$} \\
\hline Advisors’ Attitude Indicators & Student Performance Indicators \\
\hline 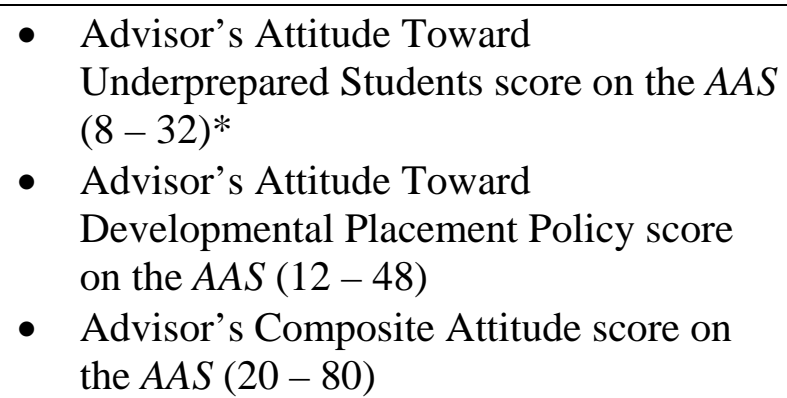 & $\begin{array}{ll}- & \text { Overall first semester GPA }(0.0-4.0) \\
- & \text { College-level course grades }(0.0-4.0) \\
- & \text { Developmental course grades }(0.0-4.0) \\
- & \text { College-level course completion rates } \\
& (0-100 \%) \\
- & \text { Developmental course completion rates } \\
& (0-100 \%)\end{array}$ \\
\hline
\end{tabular}

*The potential range of scores is listed in parentheses after each variable.

This first part of Question 2 had an explanatory purpose and was used to identify variables (student performance indicators) worthy of further study. As Fraenkel and Wallen (2000) point out, explanatory studies are appropriately used as preliminary investigations of a number of variables believed to be related to a more complex variable.

The design for Research Question 2a can be depicted with a straightforward diagram of the matched pair relationships under investigation:

\begin{tabular}{|l|c|c|}
\hline Advisees & \multicolumn{2}{|c|}{ Observations } \\
& Advisor's Attitude & Advisee's Semester GPA \\
\hline A & $\#$ & $\#$ \\
B & $\#$ & $\#$ \\
C & $\#$ & $\#$ \\
\hline
\end{tabular}

However, the actual correlation table will be more extensive because the three indicators of advisors' attitude were correlated with each student performance indicator, resulting in 15 correlational analyses. 
The follow-up question, Research Question 2b, had a predictive purpose and required the use of a more complex correlational technique, multiple regression analysis. Multiple regression analysis, which "enables researchers to determine a correlation between a criterion variable and the best combination of two or more predictor variables” (Fraenkel \& Wallen, 2000, p. 363), was used to account for differences in student performance.

\begin{tabular}{|c|c|}
\hline \multicolumn{2}{|c|}{$\begin{array}{l}\text { 2b. Do selected student factors account for variations in student performance? (Five } \\
\text { multiple regression analyses) }\end{array}$} \\
\hline $\begin{array}{l}\text { Predictor Variables } \\
\text { (Student Factors) }\end{array}$ & $\begin{array}{c}\text { Criterion Variables } \\
\text { (Student Performance Indicators) }\end{array}$ \\
\hline 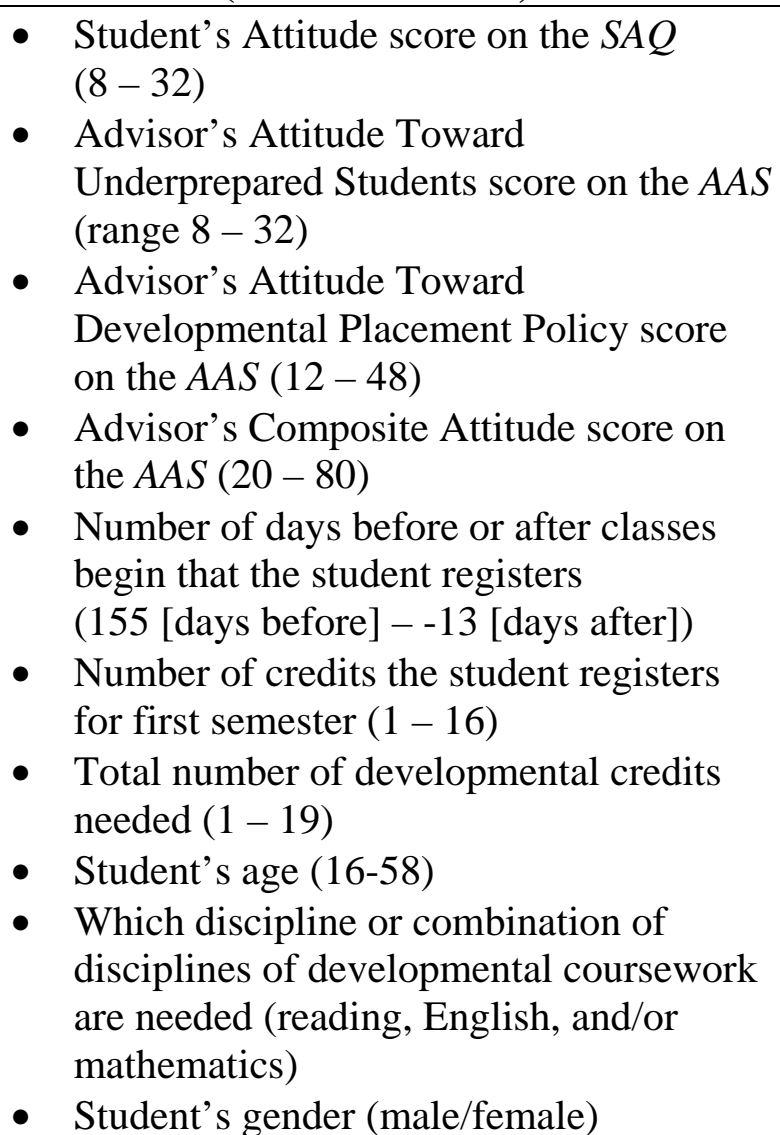 & $\begin{array}{ll}\text { - } & \text { Overall first semester GPA }(0.0-4.0) \\
\text { - } & \text { College-level course grades }(0.0-4.0) \\
\text { - } & \text { Developmental course grades }(0.0-4.0) \\
\text { - } & \text { College-level course completion rates } \\
& (0-100 \%) \\
\text { - } & \text { Developmental course completion rates } \\
& (0-100 \%)\end{array}$ \\
\hline
\end{tabular}

The predictor variables included the student's own attitude toward developmental placement, his or her advisor's attitude scores, number of days before or after classes begin that the student registers, number of credits the student registers for first semester, total number of developmental credits needed, the student's age, which discipline or combination of disciplines 
of developmental coursework he or she needs, and the student's gender. Most of the predictor variables were continuous; only the last two listed were categorical. Thus, five multiple regression analyses were against overall first semester GPA, college-level course grades, developmental course grades, college-level course completion rates, and developmental course completion rates, respectively.

Research Questions 3 also was addressed through a correlational design. Three separate correlations were calculated to find the relationship between students' awareness of their advisors' attitude and each of the three indicators of advisors' attitudes (Advisor's Attitude Toward Underprepared Students score, Advisor's Attitude Toward Developmental Placement Policy score, and Advisor’s Composite Attitude score).

3. Is there a statistically significant relationship between advisors' attitudes toward developmental placement and advisees' perception of their advisors' attitude? (Three correlations with matched advisor/advisee data)

\section{Advisor Attitude Indicators}

- Advisor's Attitude Toward Underprepared Students score on the AAS (range 8 - 32)

- Advisor's Attitude Toward Developmental Placement Policy score on the AAS (range $12-48$ )

- Advisor's Composite Attitude score on the AAS (range 20-80)

Two follow-up correlations were then calculated to determine whether students' perception of advisors' attitudes were related to students' awareness of their advisors' activity or to students' own attitudes toward developmental placement.

Research Question 4a was explored through survey research. Descriptive statistics were run on survey data from all student participants, item-by-item, on Part 5 (Perceived Helpfulness of Advising Activities) of the $S A Q$. The frequency that students reported their advisor 
performing each activity was tabulated, and the mean Perceived Helpfulness score for each item was calculated. In addition, Student's open-ended comments were analyzed and summarized in order to characterize students' perceptions of which advising activities they found most helpful.

\section{4a. Which advising activities to advisees perceive as being helpful?}

- Frequency that each item in Part 5 of the $S A Q$ was rated as Very Helpful, Helpful, Sort of Helpful, and Not at All, respectively

- Mean Perceived Helpfulness score and standard deviation for each item in Part 5 of the SAQ (0-4)

- Summary of open-ended comments on the $S A Q$

Research Question 4b was also explored through survey research. Descriptive statistics were run on survey data from all student participants, item-by-item, on Part 6 (Perceived Influence on Performance) of the $S A Q$. The frequency that students reported being influenced in each particular way was tabulated, and the mean Perceived Influence on Performance score for each item was calculated. In addition, Student's open-ended comments were analyzed and summarized in order to characterize students' perceptions of in what ways they were influenced by their advisor.

4b. In what ways, if any, do advisees believe that the attitudes, words, and/or behaviors of their advisor influenced their own academic progress and success?

- Frequency that each item in Part 6 of the $S A Q$ was rated as Strongly Agree, Agree, Disagree, or Strongly Disagree, respectively

- Mean Perceived Influence on Performance score and standard deviation for each item in Part 6 of the $S A Q(0-4)$

- Summary of open-ended comments on the $S A Q$

\section{Limitations of the Study}

- During the course of data collection, it was discovered that the computer program used to generate the list of first-time students who needed at least one developmental course had a 
programming flaw that resulted in underreporting the number of students who needed to take developmental mathematics. Names of students who needed arithmetic and beginning algebra but who did not need developmental English or reading were not captured. At MCC, the arithmetic is recommended, not required, for people who score less than 36 on the arithmetic portion of the placement test. Students who needed just beginning algebra were correctly included in the study, but those who needed arithmetic as well were not. The programming error was discovered too late in the data collection process to rectify. Therefore, rather than the 763 students on the original list, the student sample should have consisted of 1,151 students, a difference of 388 students.

- The number of advisees per advisor was unbalanced, with some advisors advising only one student and others advising as many as 40. Therefore, the attitude and activity scores of very active advisors could have more statistical impact than that of less active advisors.

- Causal relationships can be argued but not conclusively shown through associational research. An attempt was made to triangulate the findings by cross-referencing advisors' selfreported information with students’ perceptions. Still, caution will be necessary when interpreting results.

- $\quad$ Since the Student Advising Questionnaire was administered approximately two and a half months into the semester, a number of students had dropped out of school by the time the surveys are administered. Non-respondents were mentioned in the write up but dropped from analysis.

\section{Researcher's Background}

Currently, the researcher is a doctoral candidate in higher education leadership at West Virginia University. In addition, she is a full-time associate professor of English and reading and 
Coordinator of Developmental Education at a community college. She is a reading specialist by training and has 16 years experience teaching and advising underprepared college students.

\section{Research Timeframe}

This research study took approximately twelve months to complete. After Human Subjects Review Board approval was obtained, the first step was to gather input from an expert panel to establish content validity of the Advisor Attitude Survey and the Student Advising Questionnaire, pilot test them, and revise them, which took place May through July, 2003. The second step, data collection, was accomplished in three phases, beginning in September 2003 and continuing through December 2003. Phase I, Administration of the Advisor Attitude Survey, began in late September 2003. Follow-up requests were sent to non-respondents in early October and again in mid October. Phase II, Administration of the Student Advising Questionnaire, began in late October and was completed by the second week of November, the time that early registration for second semester began. The final phase of data collection occurred in December after the semester had ended. Student data (grades and course completion rates) were obtained through the Office of Computer Services at that time.

After data collection was completed, data analysis and the writing of conclusions was completed December 2003 through February 2004. A complete draft of the dissertation was submitted to the doctoral committee in early March, and the revised final defended March 22, 2004. 


\section{Chapter 4:}

Results

This study explored two hypotheses about the relationships among advisors attitudes toward developmental placement, the way they perform their advising duties, and the subsequent progress and success of their advisees. Data from 43 advisors and 360 students were analyzed to answer four research questions.

Research Question 1: Is there a statistically significant relationship between advisors' attitudes toward developmental placement and the type of advising activities they perform? Research Question 1 relates to the study’s first hypothesis, that advisors perform their advising duties in accordance with their attitudes or belief systems. Six Spearman's rho correlation coefficients were calculated to determine the relationship between each of the three indicators of advisors’ attitudes (Advisor’s Attitude Toward Underprepared Students score, Advisor’s Attitude Toward Developmental Placement Policy score, and Advisor’s Composite Attitude score) and two indicators of the degree to which they engage in developmental advising activity (Advisor's Advising Activity score and Student's Awareness of Activity score).

Advisors’ Advising Activity scores were positively correlated to their Attitude Toward Underprepared Students score $(r(43)=.412, p=.006$ ) (see Table 4). However, students' Awareness of their Advisor's Activity score was statistically related to only their advisor's Attitude Toward Developmental Placement Policy score $(r(298)=-.121, p<.05)$. To follow up on those results, an additional Spearman's rho correlation coefficient was calculated between Students’ Awareness of Advising Activity scores and Advisors’ Advising Activity scores. A significant relationship was not found $(r(298)=-.004, p=.941)$. The relationship between Students' Awareness of Advising Activity and their advisors' three attitude scores were 
calculated with matched pair data, which means that the 43 advisors' scores were repeated with each student they advised. The repetition of advisor scores within the calculations could have attenuated the results.

Table 4: Correlations between Attitude and Advising Activity (Q1)

\begin{tabular}{|c|c|c|c|c|}
\hline & & $\begin{array}{c}\text { Advisors' Attitude } \\
\text { Toward Underprepared } \\
\text { Students }\end{array}$ & $\begin{array}{l}\text { Advisors' Attitude } \\
\text { Toward Developmental } \\
\text { Placement Policy }\end{array}$ & $\begin{array}{l}\text { Advisors' Composite } \\
\text { Attitude }\end{array}$ \\
\hline \multirow[t]{3}{*}{$\begin{array}{l}\text { Advisors' Advising } \\
\text { Activity }\end{array}$} & $\begin{array}{c}\text { Correlation } \\
\text { Coefficient }\end{array}$ & $.412(\star \star)$ & .058 & \\
\hline & Sig. (2-tailed) & .006 & .710 & .228 \\
\hline & $\mathrm{N}$ & 43 & 43 & 43 \\
\hline \multirow{3}{*}{$\begin{array}{l}\text { Students' } \\
\text { Awareness of } \\
\text { Advising Activity }\end{array}$} & $\begin{array}{c}\text { Correlation } \\
\text { Coefficient }\end{array}$ & -.044 & $-.121\left(^{\star}\right)$ & -.107 \\
\hline & Sig. (2-tailed) & .452 & .037 & .066 \\
\hline & $\mathrm{N}$ & 298 & 298 & 298 \\
\hline
\end{tabular}

** Correlation is significant at the 0.01 level (2-tailed).

* Correlation is significant at the 0.05 level (2-tailed).

The statistically significant results for Research Question 1 indicate that advisors' attitudes toward underprepared students were positively related to the advising activities they rate as being important to perform when registering first-time students; the more interactional their attitudes, the more likely they were to favor developmental advising activities. Advisors’ attitudes toward developmental placement policy and their composite attitudes were not related to advisors’ attitudes.

\section{Research Question 2a: Is there a statistically significant relationship between} advisors' attitudes toward developmental placement and the first-semester academic performance of their advisees? Fifteen Spearman's rho correlation coefficients were calculated between the three indicators of advisors' attitudes (Attitude Toward Underprepared Students scores, Attitude Toward Developmental Placement Policy scores, and Composite Attitude scores) and the five measures of students’ performance (developmental course grades, collegelevel course grades, overall first semester GPA, developmental course completion rates, and 
college-level course completion rates). Alpha was set at .05 for all calculations.

Performance data from the 317 students whose advisors had returned a survey were used to calculate the correlations with advisors' attitudes so that student/advisor data could be matched. The total number of student records used to calculate each of the three GPA averages differs because, although most students registered for both developmental and college-level classes, a number of students enrolled in just one type or the other. In addition, the number of students represented in the developmental and college-level course completion rate calculations is slightly higher than the number represented in each of the corresponding GPA calculations. This apparent discrepancy occurred because course instructors dropped several students for nonattendance; those students did not receive grades for those courses, yet the withdrawal from class still counted against their course completion rates. As Table 5 demonstrates, no significant

Table 5: Correlations between Advisors' Attitude Scores and Student Performance Indicators (Q2a)

\begin{tabular}{|c|c|c|c|c|}
\hline & & $\begin{array}{c}\text { Advisors' Attitude } \\
\text { Toward Underprepared } \\
\text { Students }\end{array}$ & $\begin{array}{l}\text { Advisors' Attitude } \\
\text { Toward Developmental } \\
\text { Placement Policy }\end{array}$ & $\begin{array}{c}\text { Advisors' Composite } \\
\text { Attitude }\end{array}$ \\
\hline \multirow[t]{3}{*}{$\begin{array}{l}\text { Developmental } \\
\text { Course GPA }\end{array}$} & $\begin{array}{c}\text { Correlation } \\
\text { Coefficient }\end{array}$ & .111 & .123 & .113 \\
\hline & Sig. (2-tailed) & .079 & .052 & .073 \\
\hline & $\mathrm{N}$ & 252 & 252 & 252 \\
\hline \multirow[t]{3}{*}{$\begin{array}{l}\text { College Level } \\
\text { Course GPA }\end{array}$} & $\begin{array}{c}\text { Correlation } \\
\text { Coefficient }\end{array}$ & .100 & .107 & .097 \\
\hline & Sig. (2-tailed) & .078 & .059 & .088 \\
\hline & $\mathrm{N}$ & 311 & 311 & 311 \\
\hline \multirow[t]{3}{*}{ Overall GPA } & $\begin{array}{c}\text { Correlation } \\
\text { Coefficient }\end{array}$ & .090 & .087 & .083 \\
\hline & Sig. (2-tailed) & .109 & .121 & .141 \\
\hline & $\mathrm{N}$ & 317 & 317 & 317 \\
\hline \multirow{3}{*}{$\begin{array}{l}\text { Developmental } \\
\text { Course } \\
\text { Completion } \\
\text { Rate }\end{array}$} & $\begin{array}{r}\text { Correlation } \\
\text { Coefficient }\end{array}$ & .066 & .026 & .027 \\
\hline & Sig. (2-tailed) & .295 & .677 & .665 \\
\hline & $\mathrm{N}$ & 255 & 255 & 255 \\
\hline \multirow{3}{*}{$\begin{array}{l}\text { College Course } \\
\text { Completion } \\
\text { Rate }\end{array}$} & $\begin{array}{l}\text { Correlation } \\
\text { Coefficient }\end{array}$ & .049 & .024 & .034 \\
\hline & Sig. (2-tailed) & .384 & .673 & .552 \\
\hline & $\mathrm{N}$ & 312 & 312 & 312 \\
\hline
\end{tabular}


relationships were found between advisors' attitudes toward developmental placement and the first-semester performance of their advisees.

Though the relationships were not statistically significant, the correlation coefficients between each of the advisor's attitude indicators and developmental course GPA and college course GPA were all approaching significance, with $p$-values <.1, so a follow-up procedure was conducted to rule out interference from a limitation of the study. Some advisors in the study had advised over 40 students, while others had advised just one. Because advisor/advisee data were matched, the attitude scores of more active advisors could have more weight in the calculations. To see whether this phenomenon had influenced the results, the researcher averaged the student performance measures for students advised by the same advisor and then recalculated the correlations (see Table 6).

Table 6: Correlations between Attitude Scores and Performance with Averaged Student Data (Q2a)

\begin{tabular}{|c|c|c|c|c|}
\hline & & $\begin{array}{c}\text { Advisors' Attitude } \\
\text { Toward Underprepared } \\
\text { Students }\end{array}$ & $\begin{array}{c}\text { Advisors' Attitude } \\
\text { Toward } \\
\text { Developmental } \\
\text { Placement Policy }\end{array}$ & $\begin{array}{c}\text { Advisors' Composite } \\
\text { Attitude }\end{array}$ \\
\hline $\begin{array}{l}\text { Developmental } \\
\text { Course GPA }\end{array}$ & $\begin{array}{l}\text { Correlation } \\
\text { Coefficient } \\
\text { Sig. (2-tailed) } \\
\mathrm{N}\end{array}$ & $\begin{array}{c}-.222 \\
.199 \\
35\end{array}$ & $\begin{array}{c}-.013 \\
.939 \\
35\end{array}$ & $\begin{array}{c}-.120 \\
.492 \\
35\end{array}$ \\
\hline $\begin{array}{l}\text { College Level } \\
\text { Course GPA }\end{array}$ & $\begin{array}{l}\text { Correlation } \\
\text { Coefficient } \\
\text { Sig. (2-tailed) } \\
\mathrm{N}\end{array}$ & $\begin{array}{c}-.124 \\
.439 \\
41\end{array}$ & $\begin{array}{c}.054 \\
.737 \\
41\end{array}$ & $\begin{array}{c}.000 \\
.998 \\
41\end{array}$ \\
\hline Overall GPA & $\begin{array}{l}\text { Correlation } \\
\text { Coefficient } \\
\text { Sig. (2-tailed) } \\
\mathrm{N}\end{array}$ & $\begin{array}{c}-.094 \\
.560 \\
41\end{array}$ & $\begin{array}{c}-.037 \\
.816 \\
41\end{array}$ & $\begin{array}{c}-.080 \\
.618 \\
41\end{array}$ \\
\hline $\begin{array}{l}\text { Developmental } \\
\text { Course } \\
\text { Completion } \\
\text { Rate }\end{array}$ & $\begin{array}{l}\text { Correlation } \\
\text { Coefficient } \\
\text { Sig. (2-tailed) } \\
\mathrm{N}\end{array}$ & $\begin{array}{c}-.264 \\
.125 \\
35\end{array}$ & $\begin{array}{c}-.163 \\
.350 \\
35\end{array}$ & $\begin{array}{c}-.231 \\
.183 \\
35\end{array}$ \\
\hline $\begin{array}{l}\text { College Course } \\
\text { Completion } \\
\text { Rate }\end{array}$ & $\begin{array}{l}\text { Correlation } \\
\text { Coefficient } \\
\text { Sig. (2-tailed) } \\
\mathrm{N}\end{array}$ & $\begin{array}{c}-.035 \\
.830 \\
41\end{array}$ & $\begin{array}{c}-.041 \\
.799 \\
41\end{array}$ & $\begin{array}{c}-.020 \\
.903 \\
41\end{array}$ \\
\hline
\end{tabular}

Results of the new calculations yielded similar findings; no significant relationships were 
found. Therefore, This study did not establish a relationship between advisors' attitudes toward developmental placement and advisees’ first semester performance after students met with their advisor for one pre-enrollment advising session.

\section{Research Question 2b: Do selected student factors account for variations in student}

performance? Five multiple linear regression analyses were run to determine relative importance of various student factors in predicting student performance. First, to identify interrelationships among the performance variables, Pearson's correlations were computed between developmental course grades, college-level course grades, overall first semester GPA, developmental course completion rates, and college-level course completion rates. Data from all students in the study who had scores for the various performance variables were included in the calculations, so the number of data points used in the separate calculations differed. As expected, the performance variables were all related at the $p<.05$ level, as indicated in Table 7:

Table 7: Correlations Among Student Performance Variables

\begin{tabular}{|c|c|c|c|c|c|c|}
\hline & & Dev. GPA & $\begin{array}{l}\text { College } \\
\text { GPA }\end{array}$ & $\begin{array}{l}\text { Composite } \\
\text { GPA }\end{array}$ & $\begin{array}{l}\text { Dev. Course } \\
\text { Completion } \\
\text { Rate }\end{array}$ & $\begin{array}{l}\text { College } \\
\text { Course } \\
\text { Completion } \\
\text { Rate }\end{array}$ \\
\hline $\begin{array}{l}\text { Developmental } \\
\text { GPA }\end{array}$ & $\begin{array}{l}\text { Pearson } \\
\text { Correlation } \\
\mathrm{N}\end{array}$ & $\begin{array}{c}1 \\
279\end{array}$ & & & & \\
\hline College GPA & $\begin{array}{l}\text { Pearson } \\
\text { Correlation } \\
\mathrm{N}\end{array}$ & $\begin{array}{c}.494(\star \star) \\
272 \\
\end{array}$ & $\begin{array}{c}1 \\
351 \\
\end{array}$ & & & \\
\hline Composite GPA & $\begin{array}{l}\text { Pearson } \\
\text { Correlation } \\
\mathrm{N}\end{array}$ & $\begin{array}{c}.832(* \star) \\
279\end{array}$ & $\begin{array}{c}.883\left({ }^{* *}\right) \\
351\end{array}$ & $\begin{array}{c}1 \\
358\end{array}$ & & \\
\hline $\begin{array}{l}\text { Developmental } \\
\text { Course } \\
\text { Completion Rate }\end{array}$ & $\begin{array}{l}\text { Pearson } \\
\text { Correlation } \\
\mathrm{N}\end{array}$ & $\begin{array}{c}.698\left(^{(*)}\right. \\
279\end{array}$ & $\begin{array}{c}.469\left(^{(*}\right) \\
276\end{array}$ & $\begin{array}{c}.682(* *) \\
283\end{array}$ & $\begin{array}{c}1 \\
284\end{array}$ & \\
\hline $\begin{array}{l}\text { College Level } \\
\text { Course } \\
\text { Completion Rate }\end{array}$ & $\begin{array}{l}\text { Pearson } \\
\text { Correlation } \\
\mathrm{N}\end{array}$ & $\begin{array}{c}.283(\star \star) \\
274\end{array}$ & $\begin{array}{c}.446\left(^{\star \star}\right) \\
351\end{array}$ & $\begin{array}{c}.432(\star \star) \\
353\end{array}$ & $\begin{array}{c}.370(* \star) \\
279\end{array}$ & $\begin{array}{c}1 \\
354\end{array}$ \\
\hline
\end{tabular}

** Correlation is significant at the 0.01 level (2-tailed).

Each of the five student performance indicators then was regressed against various student factors (student's attitude toward developmental placement; student's advisor's attitude 
toward developmental placement; student's advisor's advising activity; student's perception of advisor's attitude; student's awareness of advisor's activity; number of days before or after classes begin that the student registers; number of credits the student registers for first semester; total number of developmental credits needed; age; which discipline or combination of disciplines of developmental coursework (math, reading, and/or English) were needed; and gender). Predictors were entered stepwise, and four of the equations reached significance. The intercept, unstandardized beta weights, and raw scores were used in each equation.

The equation for predicting developmental course grades with age, gender, and students’ Awareness of Advising Activity scores reached significance $(F(3,225)=6.268, p<.05)$, with an $R^{2}$ of 7.7. A student's predicted GPA in developmental classes is equal to $2.395+.026$ (AGE) .361 (GENDER) - .030(AWARENESS OF ACTIVITY), when gender is coded as $0=$ Female, 1 = Male. Older students, female students, and students who were less aware of their advisor's activity were slightly more likely to have higher grades in developmental classes. Age, gender, and students' Awareness of Advising Activity scores were significant predictors of developmental grades, with $p<.05$.

A second multiple linear regression equation was calculated to predict students' GPA in college-level classes. Overall, the equation was significant using age, perception of their advisor's attitude, and the number of days before or after classes began that they registered; $12.7 \%$ of the variance in grades for college-level classes was explained $(F(3,269)=13.024, p$ $<.05)$. A student's predicted GPA in college-level classes is equal to $.079+.047$ (AGE) + .049(PERCEPTION OF ADVISORS' ATTITUDES) - .005(NUMBER OF DAYS BEFORE OR AFTER CLASS THE STUDENT REGISTERED). Older students, students who perceived their advisor to have a more positive attitude, and students who registered early were slightly more 
likely to have higher grades in college-level classes. Age, students' Perception of Advisors' Attitude scores, and number of days before or after class that the student registered were significant predictors of college-level grades, with $p<.05$.

The regression equation for predicting composite GPA with age, gender, number of developmental credits needed, and number of days before or after classes began was significant $(F(4,274)=11.642, p<.05)$, and explains $14.5 \%$ of the variance in overall GPA. A student's predicted overall GPA is equal to $2.037+.040$ (AGE) - .322(GENDER) -.038 (NUMBER OF DEVELOPMENTAL CREDITS NEEDED) - .004(NUMBER OF DAYS BEFORE OR AFTER CLASS THE STUDENT REGISTERED). Older students, females, students who need fewer developmental credits, and students who register early are slightly more likely to have higher overall GPAs. The four predictors in the model were significant, with $p<.05$.

The regression equation predicting developmental course completion rate with the number of developmental credits needed managed to reach significance $(F(1,230)=5.785, p$ $<.05$ ), but it explains only $2.5 \%$ of the variance. A student's predicted developmental course completion rate is equal to .965 - .013(NUMBER OF DEVELOPMENTAL CREDITS NEEDED).

The equation for predicting college-level course completion rate was not significant. Therefore, no predictive equation is reported.

To summarize, several factors were found to predict student performance. Age, gender, and Awareness of Advising Activity were significant predictors of GPA in developmental courses. Age, perception of advisors' attitude, and number of days before or after the semester began that students registered were significant predictors of GPA in college level courses. Four factors were significant predictors of Overall GPA, which included grades in both developmental 
and college level courses. Age, gender, number of developmental credits needed, and number of days before or after the semester began that students registered together accounted for $14.5 \%$ of the variance in Overall GPA. The only statistically significant predictor of developmental course completion rate was number of developmental credits needed, and no significant predictors were found for college level course completion rate.

\section{Research Question 3: Is there a statistically significant relationship between advisors'} attitudes toward developmental placement and advisees' perception of their advisors' attitude? Three Spearman's rho correlation coefficients were calculated to determine whether there is a relationship between the advisors’ attitudes and students' perceptions of their advisors' attitude. Data from the forty-three advisors were matched with their 317 advisees, resulting in the repetition of active advisors' attitude scores within the data set. This procedure was intended to determine whether students were aware of how their advisors felt about developmental placement. Students’ Perception of Advisors' Attitude scores on the SAQ were run against the three indicators of advisors' attitudes from the AAS. No statistically significant relationships were found (see Table 8). Students’ perceptions of their advisors' attitude did not correlate with any of the advisor attitude indicators.

Table 8: Correlations between Students' Perceptions and Advisors' Attitudes (Q3)

\begin{tabular}{|ll|c|c|c|c|c|}
\hline & \multicolumn{1}{|c|}{$\begin{array}{c}\text { Advisors' } \\
\text { Attitudes } \\
\text { Toward } \\
\text { Underprepared } \\
\text { Students }\end{array}$} & $\begin{array}{c}\text { Advisors' } \\
\text { Attitudes } \\
\text { Toward } \\
\text { Developmental } \\
\text { Placement } \\
\text { Policy }\end{array}$ & $\begin{array}{c}\text { Advisors' } \\
\text { Composite } \\
\text { Attitude }\end{array}$ & $\begin{array}{c}\text { Students' } \\
\text { Attitudes }\end{array}$ & $\begin{array}{c}\text { Students' } \\
\text { Awareness of } \\
\text { Advisors' } \\
\text { Activity }\end{array}$ \\
\hline $\begin{array}{l}\text { Students' } \\
\begin{array}{l}\text { Perception } \\
\text { of Advisors' } \\
\text { Attitude }\end{array}\end{array}$ & $\begin{array}{l}\text { Correlation } \\
\text { Coefficient } \\
\text { tailed) }\end{array}$ & .040 & -.046 & -.033 & $.221\left({ }^{* *}\right)$ & $.429(* *)$ \\
\hline
\end{tabular}

** Correlation is significant at the 0.01 level (2-tailed). 
However, when two additional correlation analyses were run relating Students' Perceptions of Advisors’ Attitudes to Students' Attitudes and to Students’ Awareness of Advisors’ Activity, significant relationships were found. Statistical results revealed a small but significant relationship between Students' Perceptions of Advisors' Attitude scores and the students' own attitudes toward developmental placement $(r(305)=.221, p<.01)$. A slightly stronger correlation was found between students' perceptions of their advisors' attitudes and students' awareness of their advisors' activity $(r(297)=.429, p<.01)$. The more positive a student felt about developmental placement, the more likely he or she was to detect a positive attitude in his or her advisor, and the more positively he or she viewed the advisor's attitude, the more likely the student was to attribute high levels of advising activity to the advisor (see Table 8).

These findings indicate that students did not gain awareness of their advisors' attitudes after meeting with the advisors for one pre-enrollment advising session. However, students perceptions of their advisors' attitudes was statistically related to their own attitude toward developmental placement and to their awareness of their advisors' activity.

\section{Research Question 4a: Which advising activities do advisees perceive as being}

helpful? This research question examined, using both quantitative and qualitative measures, students' perceptions of the advising activities their advisors performed. Quantitative data was gathered from the Student Advising Questionnaire, Section 5 (Perceived Helpfulness of Advising Activities). Qualitative data was gathered through students' responses to two open-ended prompts on the $S A Q$ that asked students to provide comments about their developmental courses and their advisors.

Students completed Section 5 of the $S A Q$ in two steps. First, students were asked to 
check yes or no next to each item on a list of advising activities to indicate which activities their advisors had performed. Then, students were asked to rate on a scale of four (Very Helpful) to one (Not at All) the helpfulness of each activity their advisor had performed. The cumulative responses from all students who reported awareness of a particular activity resulted in the Perceived Helpfulness score for each activity. The number of cases reported of advisors performing individual activities ranged from 241 to 41 .

Data analysis indicated that most students believe that their advisor's actions were quite beneficial (see Table 9). All advising activities listed in Part 5 of the SAQ except one were activities recommended at least twice in the literature on advising, with the exception of "Hurried me through picking my classes for the semester," a practice directly opposed in the literature. Therefore, it is not surprising that 22 of the 23 advising activities listed the SAQ received high Perceived Helpfulness rating, with the mean student ratings ranging between “Helpful” (3) and "Very Helpful” (4). The only activity with a mean rating between "Not at All” (1) or only "Sort of Helpful” (2) was "Hurried me through picking my classes for the semester."

Table 9: Perceived Helpfulness Rating Patterns for Advising Activities (Q4a)

\begin{tabular}{|c|c|c|c|c|c|c|c|}
\hline \multirow{2}{*}{\multicolumn{2}{|c|}{$\begin{array}{l}\text { Perceived Helpfulness of Each Activity } \\
\text { (from most helpful to least helpful) }\end{array}$}} & \multirow[b]{2}{*}{$\begin{array}{l}\text { Mean } \\
\text { (StDev) }\end{array}$} & \multirow[b]{2}{*}{$\begin{array}{c}\text { Total } \\
\text { Cases } \\
\text { Reported }\end{array}$} & \multicolumn{4}{|c|}{$\begin{array}{c}\text { Percent of Total Reported } \\
\text { (Number of Individual Responses) } \\
\end{array}$} \\
\hline & & & & $\begin{array}{c}\text { Very } \\
\text { Helpful } \\
4\end{array}$ & $\begin{array}{c}\text { Helpful } \\
3\end{array}$ & $\begin{array}{c}\text { Sort of } \\
\text { Helpful } \\
2\end{array}$ & $\begin{array}{c}\text { Not at } \\
\text { All } \\
1\end{array}$ \\
\hline $5 d$. & $\begin{array}{l}\text { Took plenty of time helping me plan out what to take } \\
\text { the next few semesters }\end{array}$ & $\begin{array}{c}3.50 \\
(.658)\end{array}$ & 166 & $\begin{array}{l}58 \% \\
(97)\end{array}$ & $\begin{array}{l}34 \% \\
(56)\end{array}$ & $\begin{array}{r}7 \% \\
(12)\end{array}$ & $\begin{array}{l}1 \% \\
(1)\end{array}$ \\
\hline & $\begin{array}{l}\text { Talked to me about how to manage my time while in } \\
\text { college }\end{array}$ & $\begin{array}{c}3.47 \\
(.685)\end{array}$ & 120 & $\begin{array}{l}56 \% \\
(67)\end{array}$ & $\begin{array}{l}37 \% \\
(44)\end{array}$ & $\begin{array}{l}5 \% \\
(7)\end{array}$ & $\begin{array}{l}2 \% \\
(2)\end{array}$ \\
\hline & $\begin{array}{l}\text { Helped me make a long-range plan for finishing my } \\
\text { degree }\end{array}$ & $\begin{array}{l}3.47 \\
(.670)\end{array}$ & 92 & $\begin{array}{l}55 \% \\
(51)\end{array}$ & $\begin{array}{l}40 \% \\
(34)\end{array}$ & $\begin{array}{l}6 \% \\
(6)\end{array}$ & $\begin{array}{l}1 \% \\
(1)\end{array}$ \\
\hline & Explained the course requirements in my major & $\begin{array}{l}3.45 \\
(.663)\end{array}$ & 241 & $\begin{array}{l}54 \% \\
(130)\end{array}$ & $\begin{array}{l}37 \% \\
(90)\end{array}$ & $\begin{array}{l}8 \% \\
(20)\end{array}$ & $\begin{array}{l}.4 \% \\
(1)\end{array}$ \\
\hline & $\begin{array}{l}\text { Asked me what time of day I usually concentrate } \\
\text { best }\end{array}$ & $\begin{array}{l}3.44 \\
(.626)\end{array}$ & 112 & $\begin{array}{l}51 \% \\
(57)\end{array}$ & $\begin{array}{l}42 \% \\
(47)\end{array}$ & $\begin{array}{l}7 \% \\
(8)\end{array}$ & $\begin{array}{l}0 \% \\
(0)\end{array}$ \\
\hline & $\begin{array}{l}\text { Asked me to check back in with him/her several } \\
\text { times during the semester }\end{array}$ & $\begin{array}{c}3.43 \\
(.747)\end{array}$ & 104 & $\begin{array}{l}57 \% \\
(59)\end{array}$ & $\begin{array}{l}32 \% \\
(33)\end{array}$ & $\begin{array}{l}10 \% \\
(10)\end{array}$ & $\begin{array}{l}2 \% \\
(2)\end{array}$ \\
\hline
\end{tabular}




\begin{tabular}{|c|c|c|c|c|c|c|c|}
\hline \multirow{2}{*}{\multicolumn{2}{|c|}{$\begin{array}{l}\text { Perceived Helpfulness of Each Activity } \\
\text { (from most helpful to least helpful) }\end{array}$}} & \multirow[b]{2}{*}{$\begin{array}{l}\text { Mean } \\
\text { (StDev) }\end{array}$} & \multirow[b]{2}{*}{$\begin{array}{c}\text { Total } \\
\text { Cases } \\
\text { Reported } \\
\end{array}$} & \multicolumn{4}{|c|}{$\begin{array}{c}\text { Percent of Total Reported }{ }^{*} \\
\text { (Number of Individual Responses) } \\
\end{array}$} \\
\hline & & & & $\begin{array}{l}\text { Very } \\
\text { Helpful } \\
4\end{array}$ & $\begin{array}{c}\text { Helpful } \\
3\end{array}$ & $\begin{array}{l}\text { Sort of } \\
\text { Helpful } \\
2\end{array}$ & $\begin{array}{c}\text { Not at } \\
\text { All } \\
1\end{array}$ \\
\hline & $\begin{array}{l}\text { Described the differences between two course } \\
\text { options }\end{array}$ & $\begin{array}{c}3.40 \\
(.642)\end{array}$ & 199 & $\begin{array}{l}48 \% \\
(95)\end{array}$ & $\begin{array}{l}45 \% \\
(89)\end{array}$ & $\begin{array}{c}7 \% \\
(14)\end{array}$ & $\begin{array}{l}.5 \% \\
(1)\end{array}$ \\
\hline $5 a$. & Talked to me without an appointment & $\begin{array}{c}3.39 \\
(.725)\end{array}$ & 176 & $\begin{array}{l}52 \% \\
(92)\end{array}$ & $\begin{array}{l}36 \% \\
(63)\end{array}$ & $\begin{array}{l}11 \% \\
(19)\end{array}$ & $\begin{array}{l}1 \% \\
(2)\end{array}$ \\
\hline & $\begin{array}{l}\text { Told me how to get a waiver from developmental } \\
\text { classes }\end{array}$ & $\begin{array}{c}3.39 \\
(.770)\end{array}$ & 41 & $\begin{array}{l}54 \% \\
(22)\end{array}$ & $\begin{array}{l}34 \% \\
(14)\end{array}$ & $\begin{array}{c}19 \% \\
(4)\end{array}$ & $\begin{array}{l}2 \% \\
(1)\end{array}$ \\
\hline & Explained registration procedures & $\begin{array}{c}3.39 \\
(.665)\end{array}$ & 228 & $\begin{array}{l}50 \% \\
(113)\end{array}$ & $\begin{array}{l}41 \% \\
(93)\end{array}$ & $\begin{array}{l}10 \% \\
(23)\end{array}$ & $\begin{array}{l}0 \% \\
(0)\end{array}$ \\
\hline & Discussed study skills with me & $\begin{array}{c}3.38 \\
(.653) \\
\end{array}$ & 86 & $\begin{array}{l}48 \% \\
(41)\end{array}$ & $\begin{array}{l}43 \% \\
(37) \\
\end{array}$ & $\begin{array}{l}9 \% \\
(8)\end{array}$ & $\begin{array}{l}0 \% \\
(0)\end{array}$ \\
\hline & Helped me realize what to expect from my classes & $\begin{array}{l}3.36 \\
(.621)\end{array}$ & 184 & $\begin{array}{l}44 \% \\
(81)\end{array}$ & $\begin{array}{l}48 \% \\
(89)\end{array}$ & $\begin{array}{l}8 \% \\
(14)\end{array}$ & $\begin{array}{l}0 \% \\
(0)\end{array}$ \\
\hline & $\begin{array}{l}\text { Helped me think about balancing work hours with } \\
\text { school hours }\end{array}$ & $\begin{array}{c}3.34 \\
(.806) \\
\end{array}$ & 138 & $\begin{array}{l}51 \% \\
(71)\end{array}$ & $\begin{array}{l}35 \% \\
(48)\end{array}$ & $\begin{array}{l}10 \% \\
(14)\end{array}$ & $\begin{array}{l}4 \% \\
(5)\end{array}$ \\
\hline & Suggested I get a tutor at the start of the semester & $\begin{array}{c}3.33 \\
(.738)\end{array}$ & 45 & $\begin{array}{l}47 \% \\
(21)\end{array}$ & $\begin{array}{l}42 \% \\
(19)\end{array}$ & $\begin{array}{l}9 \% \\
(4)\end{array}$ & $\begin{array}{l}2 \% \\
(1)\end{array}$ \\
\hline 5j. & $\begin{array}{l}\text { Told me how well past students who took } \\
\text { developmental courses have done in school }\end{array}$ & $\begin{array}{c}3.31 \\
(.661)\end{array}$ & 74 & $\begin{array}{l}41 \% \\
(30)\end{array}$ & $\begin{array}{l}51 \% \\
(38)\end{array}$ & $\begin{array}{l}7 \% \\
(5)\end{array}$ & $\begin{array}{l}1 \% \\
(1)\end{array}$ \\
\hline & Helped me explore career options & $\begin{array}{l}3.30 \\
(.749) \\
\end{array}$ & 93 & $\begin{array}{l}46 \% \\
(43) \\
\end{array}$ & $\begin{array}{l}39 \% \\
(36)\end{array}$ & $\begin{array}{l}14 \% \\
(13)\end{array}$ & $\begin{array}{l}1 \% \\
(1)\end{array}$ \\
\hline & Asked me questions about why I picked my major & $\begin{array}{c}3.28 \\
(.717)\end{array}$ & 137 & $\begin{array}{l}42 \% \\
(58)\end{array}$ & $\begin{array}{l}45 \% \\
(62)\end{array}$ & $\begin{array}{l}12 \% \\
(16)\end{array}$ & $\begin{array}{l}2 \% \\
(2)\end{array}$ \\
\hline & $\begin{array}{l}\text { Explained the importance of having the basic skills } \\
\text { necessary for college success }\end{array}$ & $\begin{array}{c}3.24 \\
(.620) \\
\end{array}$ & 191 & $\begin{array}{l}34 \% \\
(65)\end{array}$ & $\begin{array}{l}56 \% \\
(107) \\
\end{array}$ & $\begin{array}{l}10 \% \\
(19)\end{array}$ & $\begin{array}{l}0 \% \\
(0)\end{array}$ \\
\hline & $\begin{array}{l}\text { Reassured me that lots of students need to take } \\
\text { brush-up courses }\end{array}$ & $\begin{array}{c}3.24 \\
(.646) \\
\end{array}$ & 187 & $\begin{array}{l}35 \% \\
(66)\end{array}$ & $\begin{array}{l}53 \% \\
(98)\end{array}$ & $\begin{array}{l}12 \% \\
(22)\end{array}$ & $\begin{array}{l}0 \% \\
(0)\end{array}$ \\
\hline & Encouraged me to get involved with a study group & $\begin{array}{c}3.23 \\
(.768)\end{array}$ & 74 & $\begin{array}{l}39 \% \\
(29)\end{array}$ & $\begin{array}{l}49 \% \\
(36)\end{array}$ & $\begin{array}{l}8 \% \\
(6)\end{array}$ & $\begin{array}{l}4 \% \\
(3)\end{array}$ \\
\hline & $\begin{array}{l}\text { Explained why I needed to take a developmental } \\
\text { course }\end{array}$ & $\begin{array}{c}3.19 \\
(.659) \\
\end{array}$ & 241 & $\begin{array}{l}29 \% \\
(70)\end{array}$ & $\begin{array}{l}47 \% \\
(114)\end{array}$ & $\begin{array}{l}12 \% \\
(30)\end{array}$ & $\begin{array}{l}0 \% \\
(0)\end{array}$ \\
\hline & Asked me about my past academic performance & $\begin{array}{c}3.03 \\
(.797)\end{array}$ & 166 & $\begin{array}{l}28 \% \\
(47) \\
\end{array}$ & $\begin{array}{l}43 \% \\
(71) \\
\end{array}$ & $\begin{array}{l}23 \% \\
(38)\end{array}$ & $\begin{array}{l}2 \% \\
(4)\end{array}$ \\
\hline & $\begin{array}{l}\text { Hurried me through picking my classes for the } \\
\text { semester }\end{array}$ & $\begin{array}{c}1.72 \\
(.902) \\
\end{array}$ & 73 & $\begin{array}{l}6 \% \\
(4) \\
\end{array}$ & $\begin{array}{l}14 \% \\
(10)\end{array}$ & $\begin{array}{l}29 \% \\
(21) \\
\end{array}$ & $\begin{array}{l}52 \% \\
(38)\end{array}$ \\
\hline
\end{tabular}

*Percentages may not add up to exactly $100 \%$ due to rounding error.

The response pattern for the perceived helpfulness of individual advisor activities

reinforces the contention that students must be treated as individuals because their needs differ.

The response pattern for activity 5q, “Discussed study skills with me,” illustrates the point. The activity has an average Perceived Helpfulness rating of 3.38; however, that strong rating is based 
upon 127 students who reported it as being helpful or very helpful and 45 students who indicated that the same action was only sort of or not at all helpful.

Likewise, the contrast in ratings between the most helpful activity and the least helpful activity, both of which deal with time spent during an advising session, illustrates how students' perceptions can differ markedly. One hundred fifty-three (92\%) students indicated that they benefited from their advisor taking "plenty of time" helping to plan what to take the next few semesters with ratings of Very Helpful or Helpful, and yet 13 (8\%) students did not find the extra time very helpful. On the other side, 38 (52\%) students reported that being hurried through picking classes for the semester was not a helpful activity, and yet 36 (48\%) students reported benefiting from it at least a little.

Over a third $(\mathrm{N}=138)$ of the students who returned usable surveys wrote comments about their developmental classes and/or their advisors, and these comments provide a broader perspective through which to interpret students' ratings. For instance, spending "plenty of time" helping students plan what to take the next few semesters received the highest level Perceived Helpfulness rating of all the advising activities, but the differences in students' perceptions can be more fully understood by examining the 85 student comments that were related either to the time advisors spent with students or to what the advisors accomplished within that time. The range of comments reflects differing needs or expectations.

The majority (53\%) of these 85 comments were positive. Dozens expressed appreciation for an advisor's helpfulness in a very general sense, such as, "I had a great helpful advisor" and "My advisor for [a specific career program] is wonderful, need more like him.” Another dozen students specified that the advisor helped by answering many questions or helping them select the most appropriate classes: 
- [My advisor] sat down and talked to me about my schedule. He was very attentive and answered all the questions I had. If it wasn't for him, I don't know what I would have done. He is a great advisor.

- She did a great job talking and working with me. She also knew that I had two children and didn't want to make my classes any harder than they have to be.

- He is a nice man and truly has interest in his students. I felt when he helped me he chose my teachers and times because he liked their methods of teaching.

Such comments reflect students' need for answers and guidance and how those needs were met because the advisor took the time to sit down and talk.

A few students stated more directly how the advisor's time influenced them. For instance, one student commented,

[Advisor's First Name] is my advisor and I think the world of her! She is an incredible lady and I'm very excited to have her as my advisor for the next three years. She took out time for me when I dropped in without an appointment and explained lots of questions I had. She was very helpful and I am less stressed out about school.

This student “dropped in” on her advisor feeling stressed and having "lots of questions” about school. She seems impressed by the fact that the advisor "took time out" for her, and left the advising session feeling less stressed and excited that she had a connection with her advisor, this “incredible lady," for the rest of her time at the college.

Examining the importance of time spent from the opposite perspective is even more illuminating. Only 38 (10.5\%) students out of the 360 who returned usable surveys rated feeling "hurried" during the advising process as "not at all” helpful, and yet close to half $(43 \%, \mathrm{~N}=37)$ 
of the 85 open-ended comments concerning time expressed complaints about being rushed. Twenty-nine of these comments reflect a sense of resentment:

- I wasn’t happy about my advisor. I felt very rushed. The advisor seemed to be distracted, upset, and had an attitude with me. I didn’t appreciate it at all.

- The advisor that I had should have been more open to me about my options. He should have taken more time to explain my courses.

- I didn’t get to see my advisor, and the lady in the admissions office didn’t help me at all. She rushed me through everything.

- [My advisor] never mentioned any classes. He just told me what I was taking. Now I am a little behind. I didn't know [my math class] was a developmental class!! I felt he didn't take enough time to explain certain options and also he never explained the requirements for my chosen degree.

Students who made these and similar comments either needed or expected more time from their advisors. Eight additional students indicated needing more time but also understood the time constraints involved for advisors and/or gave suggestions on how to make advisors more available:

- I did not like the rushed atmosphere but I understand that he has a busy schedule. Maybe if he shared some of his responsibilities with others his students would not feel rushed. With this, I am happy to report that I have changed my advisor.

- I registered late in the time period allowed, and the office was very busy, so I really didn't spend much time with my advisor.

- She doesn't have time with each person to ask these [survey] questions. I'm actually confused on my classes. The school is very confusing -- it seems it's understaffed... 
- Need 1 advisor for [Main] campus and 1 for [Branch] campus so he/she is readily available for all students at both campuses. Also, don’t rush us through, and find out what our goals are, and help us to accomplish them.

Finally, three students, far from resenting brief advising sessions, indicated that they didn’t have much need for help or answers. Rather, they seemed content with their advisors and wanted to take care of themselves.

- I came in knowing what I wanted, so I really didn’t need anything except pointed in the right direction.

- It wasn’t that the person who helped me wasn’t helpful. But I was only taking general studies and I sort of rushed myself through the whole process.

- The woman that helped me in the front office was terrific. My "advisor" may not have asked me questions but I didn’t need her to... She couldn’t have done anything better. The range of open-ended comments indicate that some students in this study needed to spend more time with their advisors than others because they had more questions or expected more guidance, and their level of need was reflected in the Perceived Helpfulness ratings they assigned to activities 5d, “Took plenty of time helping me plan out what to take the next few semesters,” and 5c, "Hurried me through picking my classes for the semester.”

Both quantitative and qualitative results for Research Question 4a indicated that the majority of students found a wide range of activities helpful. The majority of open-ended students' comments reflected a great appreciation for the help they had received from their advisors. A small but vocal minority of students expressed dissatisfaction from feeling rushed through the advising process. 


\section{Research Question 4b: In what ways, if any, do advisees believe that the attitudes,}

words, and/or behaviors of their advisor influenced their own progress and success? While

results from Research Question 4a clearly illustrated that students found a range of advising

activities very helpful, Question 4b probed further by examining student responses to items in

Part 6 (Perceived Influence on Performance) of the Student Advising Questionnaire and students'

open-ended comments to determine in what ways students believe the things advisors said and

did influenced their performance in developmental and college level classes. Students were

asked to rate how strongly they agreed or disagreed with nine statements that completed the

sentence, "After talking to my advisor, I...." Table 10 lists the ways students reported their

advisors influenced them, from those having the strongest to weakest effect. Data from all

students in the study who responded to the items were included in the calculations, so the

number of data points used in the separate calculations differed.

Table 10: Students' Perceptions of Advisors' Influence on Performance (Q4b)

\begin{tabular}{|c|c|c|c|c|c|c|}
\hline $\begin{array}{l}\text { Perceived Influence on Performance } \\
\text { (from strongest effect to weakest effect) }\end{array}$ & & & & $\begin{array}{l}\text { age of } T c \\
\text { er of Indi }\end{array}$ & $\begin{array}{l}\text { I Cases R } \\
\text { dual Resp }\end{array}$ & \\
\hline & Mean & Cases & Strongly & Agree & Disagree & Strongly \\
\hline After talking to my advisor: & (StDev) & Reported & & 3 & 2 & \\
\hline $\begin{array}{l}\text { 6b. I became determined to prove that I could } \\
\text { succeed in college. }\end{array}$ & $\begin{array}{c}3.10 \\
(.738)\end{array}$ & 342 & $\begin{array}{l}29 \% \\
(100) \\
\end{array}$ & $\begin{array}{l}54 \% \\
(186)\end{array}$ & $\begin{array}{l}13 \% \\
(45)\end{array}$ & $\begin{array}{c}3 \% \\
(11)\end{array}$ \\
\hline $\begin{array}{l}\text { 6g. I followed at least one piece of advice my } \\
\text { advisor gave me. }\end{array}$ & $\begin{array}{c}2.94 \\
(.791) \\
\end{array}$ & 338 & $\begin{array}{l}22 \% \\
(74)\end{array}$ & $\begin{array}{l}57 \% \\
(192) \\
\end{array}$ & $\begin{array}{l}15 \% \\
(50)\end{array}$ & $\begin{array}{l}7 \% \\
(22) \\
\end{array}$ \\
\hline $\begin{array}{l}\text { 6c. I felt better about taking a developmental } \\
\text { course. }\end{array}$ & $\begin{array}{l}2.83 \\
(.814)\end{array}$ & 333 & $\begin{array}{l}20 \% \\
(66)\end{array}$ & $\begin{array}{l}50 \% \\
(166)\end{array}$ & $\begin{array}{l}24 \% \\
(80)\end{array}$ & $\begin{array}{l}6 \% \\
(21)\end{array}$ \\
\hline 6a. I felt more confident in my abilities. & $\begin{array}{c}2.81 \\
(.792)\end{array}$ & 340 & $\begin{array}{l}19 \% \\
(63)\end{array}$ & $\begin{array}{l}50 \% \\
(169)\end{array}$ & $\begin{array}{l}27 \% \\
(90)\end{array}$ & $\begin{array}{c}5 \% \\
(18)\end{array}$ \\
\hline 6f. I felt better able to talk with other faculty. & $\begin{array}{c}2.59 \\
(.782)\end{array}$ & 338 & $\begin{array}{l}11 \% \\
(37)\end{array}$ & $\begin{array}{l}44 \% \\
(149)\end{array}$ & $\begin{array}{l}38 \% \\
(127)\end{array}$ & $\begin{array}{l}7 \% \\
(25)\end{array}$ \\
\hline $\begin{array}{l}\text { 6i. I'm doing better in my college level classes } \\
\text { because of the advice my advisor gave me. }\end{array}$ & $\begin{array}{l}2.45 \\
(.867)\end{array}$ & 329 & $\begin{array}{l}13 \% \\
(41)\end{array}$ & $\begin{array}{l}33 \% \\
(108)\end{array}$ & $\begin{array}{l}42 \% \\
(138)\end{array}$ & $\begin{array}{l}13 \% \\
(42)\end{array}$ \\
\hline $\begin{array}{l}\text { 6h. I'm doing better in my developmental classes } \\
\text { because of the advice my advisor gave me. }\end{array}$ & $\begin{array}{c}2.36 \\
(.855)\end{array}$ & 325 & $\begin{array}{l}11 \% \\
(34)\end{array}$ & $\begin{array}{l}30 \% \\
(96)\end{array}$ & $\begin{array}{l}46 \% \\
(148)\end{array}$ & $\begin{array}{l}15 \% \\
(47)\end{array}$ \\
\hline $\begin{array}{l}\text { 6d. I felt worried about whether I could make it in } \\
\text { college level courses. }\end{array}$ & $\begin{array}{l}2.25 \\
(.839)\end{array}$ & 341 & $\begin{array}{l}8 \% \\
(27)\end{array}$ & $\begin{array}{l}27 \% \\
(91)\end{array}$ & $\begin{array}{l}48 \% \\
(162)\end{array}$ & $\begin{array}{l}18 \% \\
(61)\end{array}$ \\
\hline 6e. I felt discouraged. & $\begin{array}{l}1.86 \\
(.732)\end{array}$ & 341 & $\begin{array}{l}4 \% \\
(12) \\
\end{array}$ & $\begin{array}{l}10 \% \\
(34)\end{array}$ & $\begin{array}{l}55 \% \\
(188) \\
\end{array}$ & $\begin{array}{l}31 \% \\
(107)\end{array}$ \\
\hline
\end{tabular}

*Percentages may not add up to exactly $100 \%$ due to rounding error. 
The mean Perceived Influence on Performance scores in Table 10 are not dramatically high; however, the response pattern on the questions in section 6 of the $S A Q$ indicate that a significant number of students believe that talking to their advisor had several positive influences on their performance. After talking to their advisors, 286 (84\%) students reported that they became determined to prove that they could succeed in college; 232 (70\%) felt better about taking a developmental course; and 232 (68\%) felt more confident in their abilities. Conversely, a third or less of the students who responded indicated that meeting with their advisor was not influential enough to help them overcome their fears or worries about college: $46(14 \%)$ students indicated that they felt discouraged after taking to their advisor, and 118 (35\%) reported that they still felt worried about whether they could make it in college level courses. Interestingly, 266 (79\%) students reported following at least one piece of advice from their advisor, yet the majority did not believe that they were doing better because of their advisor’s advice; only 130 (41\%) reported that they were performing better in their developmental courses because of the advice their advisor had given, and 149 (46\%) students reported doing better in college-level classes because of their advisor's advice.

In addition to these ratings, 18 students commented on their questionnaire about additional ways their advisor influenced them. Five of the 18 comments referred to negative influences. For instance, one student wrote that the advisor “made me feel 'dumb’ about my score on the placement test," and two others indicated that they were now "behind” after receiving bad advice. One student felt his advisor was judging him and so became determined to prove his advisor wrong: “[My advisor] said to work little even if I had bills. He didn’t think I could handle very much. Well, I proved him wrong. I have a 3.7.” 
Three other students reported that their pre-enrollment advising session had little if any influence:

- I am doing better because of me. I already felt that I could succeed in college.

- My advisor barely had time for me. I was not hindered by her absence, yet her presence did not benefit me.

- Did not offer much advise or help in determining how my education would turn out. Ten students reported having benefited in specific, unique ways from their advisor. For instance, one student said of her advisor, "She is an awesome person who makes me want to be there to learn!” Another commented, “She helped me understand what I was up for and prepared me for my classes," and a nontraditional student revealed, "She helped me to feel confident to take classes at my age and encouraged me to continue with my education.”

A final, important influence was not stated directly, yet it was implied in over two dozen comments. Such comments suggested that students believed their advisor's caring attitude or understanding nature had a positive influence on their success as students. These students seemed to take with them from their initial advising sessions the assurance that they had someone to turn to if they had any questions or problems later during their college experience:

- She is very understanding and nice. I feel that I can talk to her about school and she helps me with my classes.

- $\quad$ She is very nice and very willing to help with whatever I need.

- [My advisor] is awesome. I know I can go to him whenever I have a problem and he will explain how I can overcome the problem.

- When I need help I go to [Advisor's First Name]. She is here where I need her and has been very wonderful to help me in all areas or points me to someone who can. 
These comments reflect how many students felt a connection to the person who helped them sign up for classes. Students frequently used derivatives of the words helpful, understanding, and caring to characterize their advisors. They appreciated having someone willing to answer their questions, and they appeared to carry away from their first encounter with their advisor the belief that they had an adult to turn to with future concerns. The implication is that students gained the assurance that someone would help them if they were ever in need.

In summary, quantitative results from exploration of Research Question 4b indicate that after meeting with their advisors for one pre-enrollment advising session, the majority of students perceived that their advisor had at least a moderate influence on their success in one or more ways. Qualitative data specified specific influences beyond those mentioned on the student survey. A small proportion of students perceived being negatively influenced by their advisors' words or activities, and a small proportion did not believe their advisor had any influence on their success. 


\section{Chapter 5:}

\section{Discussion and Recommendations}

This study can be characterized as a preliminary investigation of the relationships among academic advisors' attitudes toward developmental placement, the way advisors behave in the role of advisor, and the performance and persistence of their underprepared advisees. Two overarching hypotheses guided the study. The first hypothesis $\left(\mathrm{H}_{1}\right)$ was that advisors perform their advising duties in accordance with their attitudes or belief systems. $\mathrm{H}_{1}$ gained statistical support. The second $\left(\mathrm{H}_{2}\right)$ was that advisors' attitudes toward underprepared students and toward developmental placement policies are related to their advisees’ subsequent academic performance and perceived success. A relationship between advisors' attitudes and students’ academic performance, as measured by course grades and completion rates, was not established. However, a small but significant relationship was found between students’ perceptions of their advisors' attitudes and their academic performance. Also, qualitative data indicated that students perceive a positive influence on their success from talking to their advisor. The following chapter will discuss these findings and draw implications for advising policies, advising practices to use with underprepared students, and the professional development system for advisors at community colleges.

\section{H: Relationship between Attitude and Activity}

Two under-girding concepts gleaned from the literature formed the basis for $\mathrm{H}_{1}$ : a) mandatory assessment and placement benefit underprepared students, and b) advisors play a key role in the retention and performance of students. It is not clear from the literature if advisors' attitudes play a role in their initial contacts with underprepared students. It was hypothesized that advisors hold a range of attitudes toward the importance of mandatory assessment and 
placement into developmental courses. Those with a Laissez-Faire attitude view developmental prerequisites as loose recommendations rather than requirements, and they support students' "right to fail" by enrolling in courses for which they do not have the requisite skill, while those with a Structured attitude view developmental prerequisites as strict requirements and as vital preparation for success in college level courses (terminology adapted from Fonte’s (1997) description of two different orientations toward open access to higher education).

It was also hypothesized that advisors hold a range of attitudes toward underprepared students. Those with a Traditional attitude view underprepared students as deficient and in need of remediation to fit the campus environment, whereas those with an Interactional attitude view underprepared students as needing help integrating successfully into the college environment (terminology adapted from Aune's (2000) description of two perspectives toward students with disabilities).

The advisors in this study, indeed, held a range of attitudes along both continuums. According to responses on the Advisor Attitude Survey, advisors' attitudes toward developmental placement varied from moderate to high scores on both continuums and on the composite attitude scale (see Table 11). The Attitude Toward Underprepared Students scale has a potential score range of 8 (representing a very traditional attitude) to 32 (representing a very Interactional attitude), and the higher the score, the closer the advisor is to the perspective favored in the literature. In this study the advisors' scores ranged from 17 to 30 with a mean score of 24.8 (SD = 2.8). The Attitudes Toward Developmental Placement Policy scale has a potential score range of 12 (representing a Laissez Faire attitude toward placement) to 48 (representing a Structured attitude toward placement, the view favored in the literature). The advisors' scores ranged from 26 to 47 with a mean score of $40.1(S D=5.1)$. The mean Composite Attitude score, which is 
determined by adding the other two scores together, has a potential range of 20 to 80; the mean score in this study was $64.8(S D=6.6)$.

Table 11: Range and Frequency of Advisors' Scores on Three Attitude Scales

\begin{tabular}{|c|c|c|c|c|c|c|}
\hline & \multicolumn{6}{|c|}{$\leftarrow$ Attitude Toward Underprepared Students $\rightarrow$} \\
\hline Score Range & 8-12 & $13-16$ & $17-20$ & 21-24 & $25-28$ & $29-32$ \\
\hline $\begin{array}{c}\text { Score } \\
\text { Frequencies }\end{array}$ & 0 & 0 & 2 & 19 & 18 & 4 \\
\hline & \multicolumn{2}{|c|}{$\begin{array}{l}\text { Laissez Faire } \\
\text { Attitude }\end{array}$} & \multicolumn{3}{|c|}{$\begin{array}{c}\leftarrow \text { Attitude Toward Developmental } \rightarrow \\
\text { Placement Policy }\end{array}$} & $\begin{array}{l}\text { Structural } \\
\text { Attitude }\end{array}$ \\
\hline Score Range & $12-18$ & $19-24$ & $25-30$ & $31-36$ & $37-42$ & $43-48$ \\
\hline $\begin{array}{l}\text { Score } \\
\text { Frequencies }\end{array}$ & 0 & 0 & 3 & 6 & 11 & 15 \\
\hline & \multicolumn{5}{|c|}{$\begin{array}{l}\text { Attitude } \\
\text { Least Favored } \\
\text { in the Literature }\end{array}$} & $\begin{array}{l}\text { Attitude } \\
\text { Most Favored } \\
\text { in the Literature }\end{array}$ \\
\hline Score Range & $20-30$ & $31-40$ & $41-50$ & $51-60$ & $61-70$ & $71-80$ \\
\hline $\begin{array}{c}\text { Score } \\
\text { Frequencies }\end{array}$ & 0 & 0 & 2 & 8 & 25 & 8 \\
\hline
\end{tabular}

Attitudes toward underprepared students and attitudes toward developmental placement policy have not previously been studied as theoretical constructs. Results from this study indicate that advisors' attitudes in these two subcategories vary in measurable ways, providing preliminary evidence of their validity as attitudinal constructs. Additional study is needed to understand overall attitude toward developmental placement more completely and to determine the extent to which these two constructs (attitudes toward underpepared students and developmental placement policy) influence advisors’ overall attitude.

Not only did the attitudes of advisors in this study vary, but also the types of activities they reported performing with first-time, underprepared community college students varied (see Table 12). On the AAS's Advising Activity scale, the potential scores range from 30 to 120 . The higher the score, the closer an advisor is to acting in accordance to the Developmental Advising 
model, which is favored in the literature over the Prescriptive model. In this study, the advisors' scores ranged from 58 to 112, with a mean score of $95.9(S D=12.0)$.

Table 12: Range and Frequency of Advisors' Scores on the Advising Activity Scale

\begin{tabular}{|c|c|c|c|c|c|c|}
\hline \multicolumn{3}{|c}{$\begin{array}{c}\text { Prescriptive } \\
\text { Advising Model }\end{array}$} & $\leftarrow$ Advising Activity $\rightarrow$ & \multicolumn{2}{c|}{$\begin{array}{c}\text { Developmental } \\
\text { Advising Model }\end{array}$} \\
\hline Score Range & $30-45$ & $46-60$ & $61-75$ & $76-90$ & $91-105$ & $106-120$ \\
\hline $\begin{array}{c}\text { Score } \\
\text { Frequencies }\end{array}$ & 0 & 1 & 2 & 11 & 19 & 11 \\
\hline
\end{tabular}

The important point to note is that variations in advising activity were positively related to variations in attitude. The more interactional and structural an advisor's attitude was, the more likely that advisor was to perform activities consistent with the Developmental Advising Model.

Contribution to the literature. This study took a new approach to exploring the role advisors play in the retention and success of students. Previous studies have established that mandatory basic skills assessment and placement in developmental coursework have a direct influence on lowering the attrition rates and raising the grade point averages of underprepared students (Amey \& Long, 1998; Hadden, 2000; Roueche \& Roueche, 1999a; Rounds \& Anderson, 1985). Likewise, researchers have established a direct, causal relationship between academic advising and the persistence and academic performance of underprepared students (King, 1993a, 1993b; Morante, 1989, 2001). Until now, however, researchers have not explored the interrelationship between these two findings by documenting advisors' attitudes toward developmental placement. This study has established that advisors’ attitudes toward both underprepared students and developmental placement policy can be measured. More importantly, it has established that advisors’ attitudes toward developmental placement were positively related to the advising activities they were likely to perform when registering first- 
time students; the more Interactional and Structural their attitudes were, the more likely they were to favor developmental advising activities.

\section{$\mathrm{H}_{2}:$ Relationship between Advisors' Attitudes and Students' Performance and Success}

Investigation of the first hypothesis established that advisors held a range of attitudes toward developmental placement and that they tended to act in accordance with their attitudes. The study's second overarching hypothesis was that these differences would be related to students’ academic performance and perceived success. This study differentiated between actual student performance (as measured by grades in developmental classes, grades in college classes, overall grade point average, developmental course completion rate, and college course completion rate) and students’ perceived success (as measured by self-reported data on the Student Advising Questionnaire). Results were mixed, with no statistical support for the relationship between advisors’ attitudes and student performance but with qualitative support for the relationship to students’ perceived success.

After one visit with their advisor for pre-enrollment advising, students neither demonstrated awareness of their advisor's attitude toward developmental placement nor accurately remember which or how many advising activities their advisor performed, so a statistical relationship was not established between advisors’ attitudes and student performance. A possible explanation for these non-significant findings could be that the distributions of advisors' attitude scores in this study were negatively skewed (see Figure 6). When all the matched advisor/advisee data were used $(\mathrm{N}=317)$, advisors' scores did not fall on a normal curve, whereas students’ perceptions of the advisors' attitudes did (see Figure 7). Approximately $50 \%$ of advisors' composite attitude scores range from 46 to 69, a span of 15 points, whereas the other $50 \%$ ranged from 70.5 to 77 , a span of just 6.5 points (see Figure 6 ). 


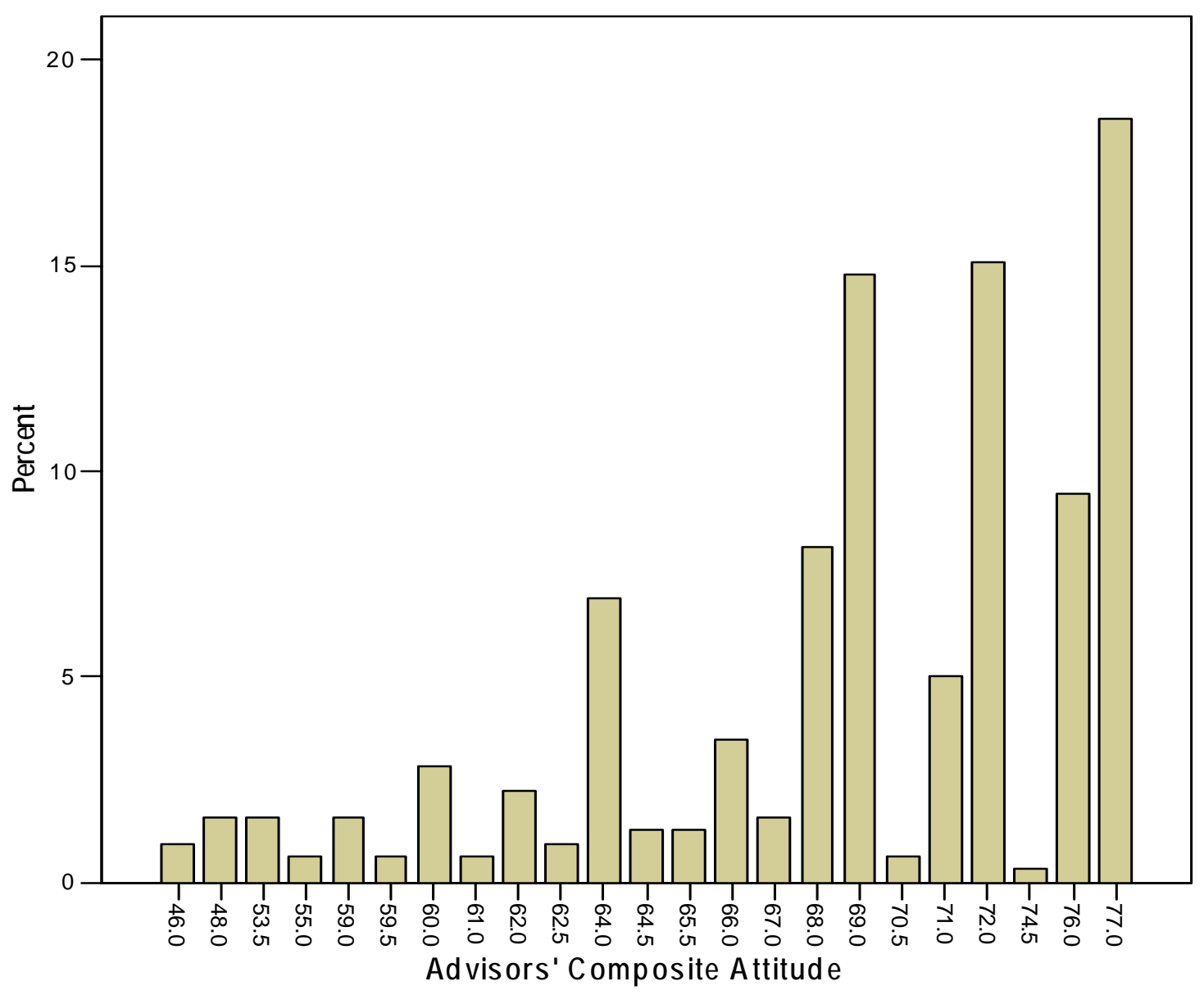

Figure 6: Frequency of Advisors' Attitude Scores in Matched Pair Data Set

Figure 7, on the other hand, demonstrates that approximately 50\% of students'

perceptions of their advisors' attitude scores center around the mean score of 28.5. Only 43 advisors advised the 317 students, and the number of students each advisor worked with varied. Yet in the matched pair data set, the attitude scores of each student's advisor were paired with the student's performance data. That means that the scores of very active advisors would weigh more heavily in all statistical calculations than would the scores of advisors who worked with only one or two students. When the attitude scores of the 43 individual advisors were graphed, scores fell roughly into a normal distribution, as exemplified in Figure 8. 


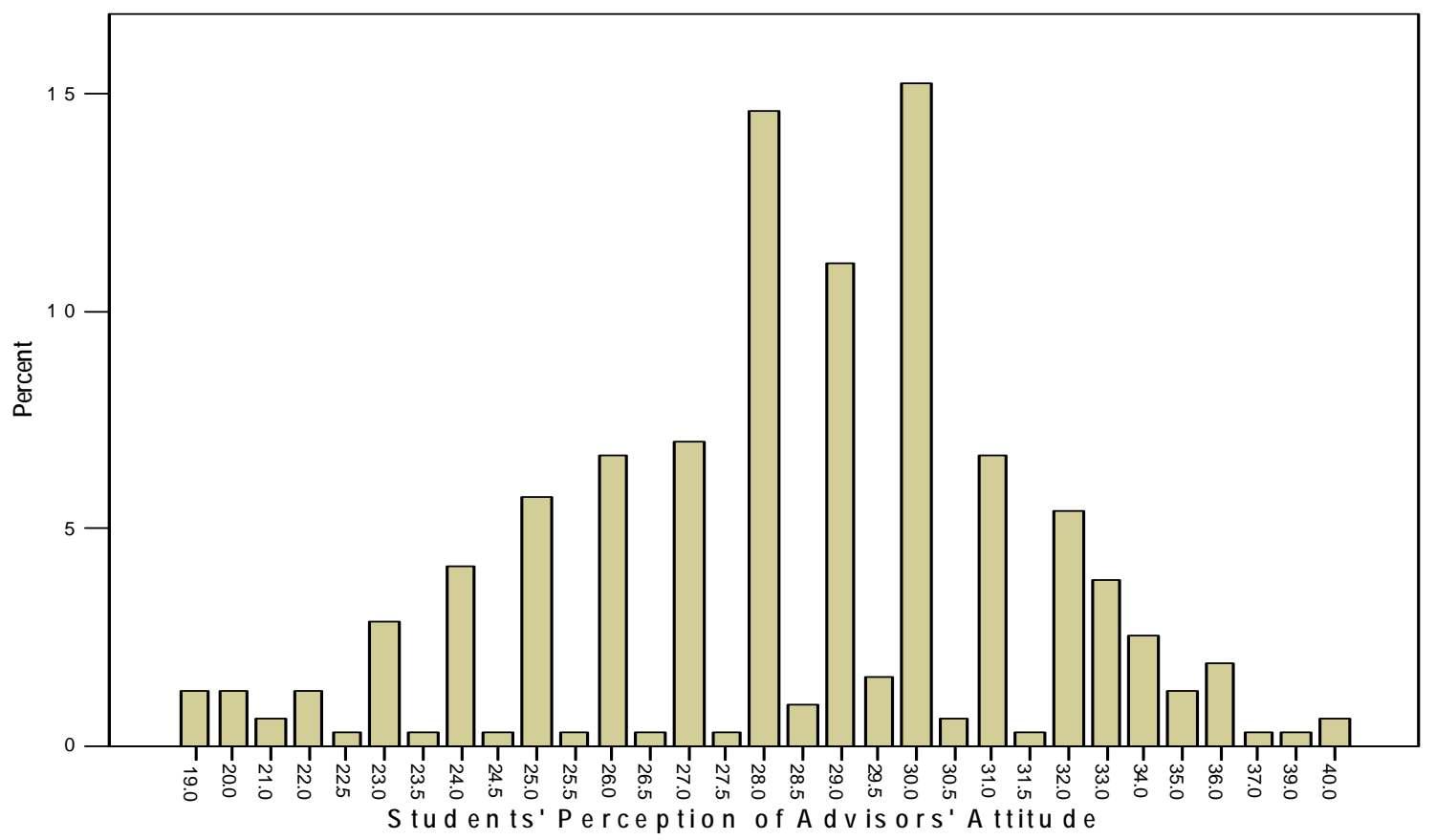

Figure 7: Frequencies of Students' Perceptions of Advisors' Attitude Scores

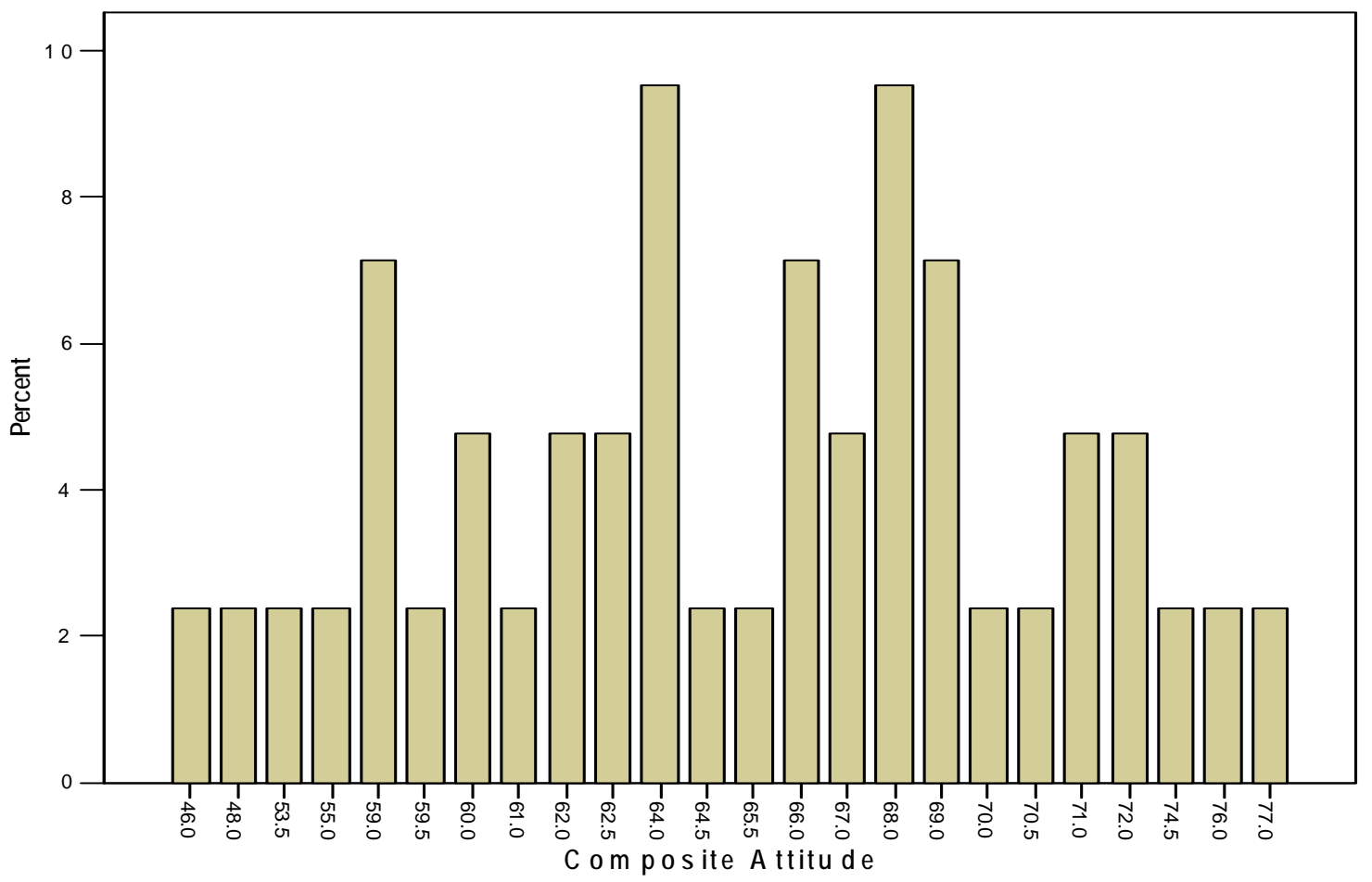

Figure 8: Frequency of Advisors' Attitude Scores When Each Score Counts Once 
When the correlation between advisors' attitudes and students' academic performance were recalculated using averaged student data, so that each advisor's score was used only once, the relationship between the two still failed to reach significance.

Student performance was not related to advisors' attitudes, and yet student performance was related to the students' perceptions of their advisors' attitudes and activity. In fact, Perception of Advisor's Attitude accounted for a small but significant proportion of variation in students' grades in college-level classes. This apparently contradictory finding might be explained by the fact that this study focused on impressions formed after just one student/advisor interaction, the initial pre-enrollment advising session. The students formed their impressions of their advisor during one contact, so apparently they were able to form only very generic impressions, such as the advisor being "nice" and "helpful" or "unconcerned" rather than being able to discern specific attitudes toward developmental placement. It is possible that stronger results would be seen if similar research procedures were followed after advisees had worked with their advisors for a year or more. The developmental advising model is a process that is implemented over time, so a relationship between advisors' attitudes and student performance might be more likely to develop over time.

\section{Recommendations for Further Study}

Student perceptions of advisors' attitudes and activity. This study did not find a relationship between students' perception of their advisors' attitudes toward developmental placement and the advisors' actual, self-reported attitude, most likely indicating that students were not able to form an accurate impression of this component of the advisors' attitude after just one visit. This study should be replicated with second-year students to determine whether 
students' perceptions become more accurate after several meetings with their advisor and, if so, whether advisors' attitudes are then found to be related to student performance.

Likewise, the study found neither a relationship between students' academic performance (as measured by grades and course completion rates) and the advisors' actual attitudes toward placement, nor a relationship between students' performance and advisors' actual activities. However, as previously noted, student performance was related to students' perception of advisors' attitude and activity. In other words, after one pre-enrollment advising session, students' perceptions about their advisors, whether right or wrong, appear to have been more important to students than what advisors actually said or did. On what basis, then, do students form their perceptions about their advisors? Their perceptions seem to be influenced more by the advisors' general demeanor than by specific words or actions. Researchers need to study both the formation and influence of students' perceptions of their advisors, possibly exploring whether there are advisor qualities that account for variations in the perceptions students form.

Student attitudes toward developmental placement. Students' responses on the Student Advising Questionnaire indicated that they, like advisors, held a range of attitudes toward developmental placement. The possible score range on the Student Attitude scale was 8 to 32; the higher a student's score, the more positive his or her attitude toward developmental placement. Three hundred and seven students answered all of the $S A Q$ items that measured student attitude. The Attitude scores of those 307 students ranged from 11 to 30, with a mean score of 21.6 (SD 3.5) (see Figure 9).

Interestingly, students' own attitudes toward developmental placement were not related to their academic performance. However, students' own attitudes were related to their perceptions about advisors' attitudes and activities, which were related to students' 


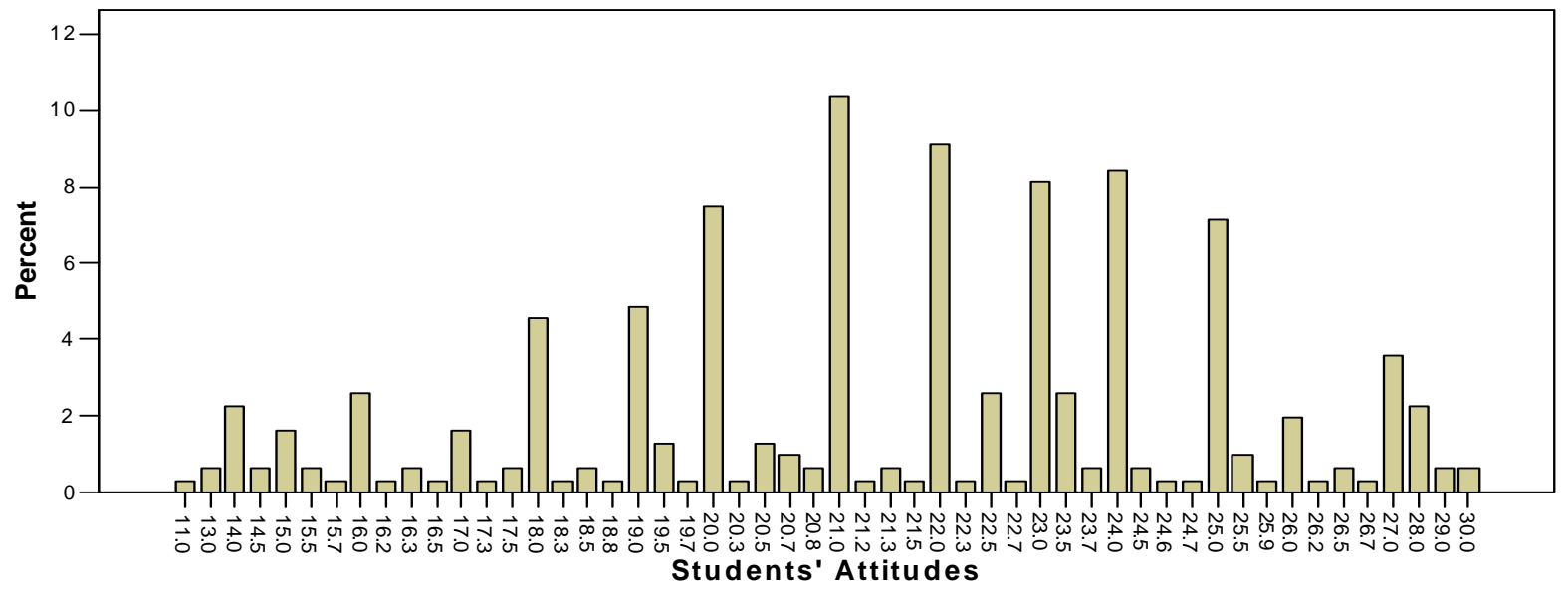

Figure 9: Frequency of Students' Attitude Scores

performance. The more positive a student felt about developmental placement, the more likely he or she was to detect a positive attitude in his or her advisor. Also, the more positively the student viewed the advisor's attitude, the more likely he or she was to attribute a high level of developmental advising activity to the advisor. Is it possible that something the advisors said or did or the advisors' general demeanor influenced students' attitudes? Students reported that they felt better about taking developmental classes after talking to their advisor. Did that "feeling better” represent just a calming of nerves, or could it have indicated a change in attitude? These questions were not addressed in this study; however, enough evidence was gathered to warrant further investigation of whether advisors' attitudes and activity are causally related to students' attitudes.

Future research also should explore the finding that students reported feeling better about taking the developmental courses after talking to their advisor. If students go into developmental classes with a more positive attitude and expectations of success, those expectations are bound to have a subtle influence on how willing a student is to persist through difficulties. 
Finally, most students reported benefiting in a number of ways from a range of activities their advisor performed. However, a small proportion of students voiced complaints about their advisors or the advising system. These negative comments should be explored further to determine if something different could be done to meet these students' needs.

Advisors' attitudes. Advisors in this study held a range of attitudes toward developmental placement, and their attitudes were related to the types of advising activities they performed with first-time college students. Again, this study established that the two were related, but further study is necessary to determine causality.

Attitude surveys. The researcher developed two new instruments to measure the advisors' attitudes and activities (Advisor Attitude Survey) and students' attitudes and perceptions (Student Advising Questionnaire). These instruments proved valuable in collecting information about how advisors viewed their role and what students found helpful. The researcher has already completed the preliminary steps necessary to establish the validity of the two instruments by drawing all survey items from the literature and by consulting an expert panel. However, the reliability of both instruments needs to be verified through the use of factor analysis, and further evidence of their validity should be gathered.

In addition, the $A A S$ and $S A Q$ should be refined to ensure that each survey item yields important information. For instance, after analyzing item responses on the $A A S$, the researcher found that one item on the survey, "Admitting underprepared students into college classes leads to lower standards," did not discriminate between advisors with high or low scores on either the Attitude Toward Underprepared Students scale or Attitude Toward Developmental Placement Policy scale. This item needs to be revised or discarded. The researcher also discovered that an 
appropriate revision of the $S A Q$ would be to replace all references to a student's "advisor" with “the person who helped you register for classes" to avoid confusion.

More substantial adaptations might also be warranted. For instance, the surveys were designed with first year students as the focus. If the overall study were to be replicated with second year students, both surveys would need to be revised.

\section{Recommendations for Practice}

Student services administrators. This study was based on the premise that the developmental advising model provides a more advantageous path for advising underprepared students than the prescriptive model. The prescriptive model views advising as a peripheral part of the academic administrative function and limits advisor activity to providing information about courses, explaining registration procedures, and enrolling students in appropriate courses (Broadbridge, 1996). In contrast, the main focus of the developmental advising model is encouraging and enhancing intentional developmental changes in students and systematically involving students in the decision-making process (Herndon, Kaiser, \& Creamer, 1996). A developmental advisor engages students in conversations and information exchanges that assist the students in clarifying their career goals and educational plans, balancing the amount of challenge and structure they offer based on the students' developmental needs (Frost, 1994; King, 1996).

In the past twenty years, many researchers and practitioners have shown that developmental advising is the most effective model for improving student retention (Crockett, 1985; Frost, 1990; Habley \& Morales, 1998; Herndon, Kasier, \& Creamer, 1996; Joseph, 2000; Levitz \& Noel, 1989; McAuliffe \& Strand, 1994; McCollum, 1998; Miller \& Alberts, 1994; Molina \& Abelman, 2000; O’Banion, 1994a, 1994b; Perry, 2001; Peterson \& McDonough, 
1985; Polson, 1994; Raushi, 1993; Spiers, 2000). Moreover, most studies comparing student preferences on advising styles indicate that almost all students prefer or are more satisfied with developmental advising than prescriptive advising, and yet those same studies also point out that students are more likely to receive prescriptive advising (Baca, 1999; Belcheir, 1999; Herndon, Kaiser, \& Creamer, 1996; Neal, 1995; Polson, 1994; Spiers, 2000; Weston, 1994).

This study highlighted a possible reason that the developmental advising model is not followed more often, at least at the community college level. Mountainside Community College, like many other two-year institutions, functions under a mixed professional advising / faculty advising model. Researchers and practitioners have long debated the relative benefits of both models, but this study did not address the differences between a centralized advising model, where professional advisors perform all advising, and a faculty model, where faculty members from students' majors perform all advising. Still, the fact that MCC functions under a mixed model has practical implications. Few students in this study visited their assigned advisors to receive their initial pre-enrollment advising. Rather, most students visited a proxy advisor in the admissions office. Again, this study did not differentiate between professional and faculty advisors, both of whom serve as proxy advisors at MCC. However, the fact that so many students saw proxy advisors (whether professional or faculty) means that those students will see a different advisor the next time they register for classes. Since the developmental model focuses on enhancing purposeful developmental changes in students, the premises of the developmental model cannot be carried out over time if students change from one advisor to another. Further research is needed to determine whether students miss out on potential benefits of pre-enrollment advising by seeing a proxy advisor and then switching to someone else. Preliminary data from this study suggest that the students who were able to establish a relationship with their assigned 
advisor from the very first visit perceived having established rapport with a caring individual, one to whom they could turn with future questions, as positively influencing their success. Research on this issue could lead to large-scale revisions of the current structure of advising systems.

Placement assessment office. Community colleges, with their open door policy, face the challenge of providing educational access to all and at the same time providing a quality education that prepares students for careers, transfer, and/or life-long learning and citizenship. Accordingly, access versus excellence at community colleges has been debated for years (Smittle, 1993). Research suggests that both access and excellence can be achieved through an effective entry program that assesses students’ basic skills and places them in appropriate coursework at the beginning of their college careers (Anderson, 1985; Smittle, 1993). Since underpreparedness is the norm rather than the exception on most two-year college campuses (King, 1993a), community colleges need to take a stand on how consistently and to what degree they enforce mandatory assessment and placement policy. Consequently, the ability for an open enrollment community college to maintain high standards is closely tied to its outlook toward developmental placement.

Fonte’s (1997) description of two different orientations toward open access to higher education, Laissez-Faire Access versus Structured Access, formed the basis for the Attitude Toward Placement Policy scale on the Advisor Attitude Survey. In his typology, the LaissezFaire Open Access viewpoint rejects restrictions placed on students that might limit their coursetaking access or interfere with their right to choose. The Structured Open Access perspective, on the other hand, endorses mandatory policies and proactive interventions that have been shown at other institutions to promote success. The appropriate office responsible for administering a 
college's placement test could use the Advisor Attitude Survey as a preliminary step to determine the degree to which advisors believe the placement system is achieving its goals and serving students effectively. Administrators, such as directors of placement testing, and advisors need research-based evidence about the quality of the college's placement system and developmental coursework in order to feel confident placing their students in developmental classes.

Those who organize professional development for advisors. The advisors in this study were likely to act in accordance with their attitudes toward underprepared students and developmental placement policy. Advisors need to believe that the policy is legitimate in order to see any reason to enforce that policy. Those who conduct advisor training sessions should be aware of the need to address advisors' attitudes. The literature is full of wonderful suggestions on how to help underprepared students succeed in college, and, indeed, this study verifies that students perceive benefiting from those activities when the advisor performs them. However, not all advisors believe that those activities are important, so merely providing advisors with information or suggestions on what to do won't necessarily lead them to change their behavior.

Advisors perform the activities that they believe are important. Therefore, advisor training needs to provide rational and research-substantiated reasons for performing suggested activities. Advisors should be taught the philosophical differences between the prescriptive and developmental advising models and shown in what ways the developmental model leads to longterm benefits for students. Advisors also should be given suggestions on the wide range of advising activities that can benefit students (such as those used in this study).

Not only should advisors be informed about the philosophical underpinnings of the developmental advising model, but they should also be made aware of the framework within which they can examine their own attitudes toward developmental placement. If advisor training 
helps advisors recognize and discuss their own attitudes toward underprepared students and toward developmental placement policy, then training facilitators might be able to address any misconceptions advisors hold.

Academic advisors. Aune (2000) urges career and academic advisors to recognize their own assumptions and how their assumptions affect their behavior: "Professionals need to examine whether they actually hold unfavorable or even hostile attitudes toward a particular group...It is important to emphasize that one's practices must be examined as rigorously as one's attitudes” (p. 58). Advisors need to recognize the fact that students notice whether the advisor is interested in the student or distracted and hurried. Several advisors in this study voiced frustration through open-ended comments that there simply wasn't enough time to perform all the “vitally important” activities. Knowing that students in this study didn’t remember the specific activities as much as their advisors' general willingness to help might ease such concerns. Knowledge that an advisor's general demeanor toward students appears to be as important, if not more so, than the specific activities that he or she performs might help advisors feel more confident in advising first-time, underprepared students.

Finally, students should be treated as individuals. This study added to the wealth of evidence that different students need, want, and expect different things from their advisors. The very complex task of advising cannot be reduced to a list of activities to perform. Effective advising requires sensitivity to what individual students need and the ability to adjust practice accordingly. 


\section{References}

Abraham, A. A., \& Creech, J. D. (2000). Reducing remedial Education: What progress are states making? Atlanta, GA: Southern Regional Education Board, Educational Benchmarks 2000 Series.

American College Testing Program. (2003). COMPASS/ESL Placement Assessment.

Amey, M. J., \& Long, P. N. (1998). Developmental course work and early placement: Success strategies for underprepared community college students. Community College Journal of Research \& Practice, 22(1), 3, 8.

Anderson, E. (1985). Forces influencing student persistence and achievement. In L. Noel, R. Levitz, D. Saluri, \& Associates (Eds.), Increasing student retention: Effective programs and practices for reducing the dropout rate (pp. 44-61). San Francisco: Jossey-Bass.

Aune, B. (2000). Career and academic advising. In H. A. Belch (Ed.), New directions for student services, no. 91. Serving students with disabilities (pp. 55-67). San Francisco: Jossey-Bass.

Baca, B. C. (1999). Developing a student retention project at Yakima Valley Community College: An analysis of first-year students. (Doctoral dissertation, Seattle University, 1999). Dissertation Abstracts International, 61, 468.

Behrman, E. H. (2000). Developmental placement decisions: Content-specific reading assessment. Journal of Developmental Education, 23(3), 12-18.

Belcheir, M. J. (1999, May). Student satisfaction and academic advising. Paper presented at the Annual Forum of the Association for Institutional Research, Seattle, WA. (ERIC Document Reproduction Service No. ED433772)

Belcheir, M. J. (2000). An evaluation of advising programs (Report No. BSU-RR-2000-02). Idaho: Boise State University, Office of Institutional Assessment. (ERIC Document Reproduction No. ED443338).

Berger, D. M. (1997, Winter). Mandatory assessment and placement: The view from an English department. In J. M. Ignash (Ed.), New directions for community colleges, no. 100. Implementing effective policies for remedial and developmental education (pp. 33-41). San Francisco: Jossey-Bass.

Bernardi, R. L., \& Castleberry, K. S. (1990). Assessment: Stopping the revolving door at Rock Valley College. Reading Horizons, 30(4), 271-276.

Billings, R. S. (2001). How student support programs, services and activities affect retention rates among community college minority students (Doctoral dissertation, University of Central Florida, 2001). Dissertation Abstracts International, 62, 1693. 
Bloom, J. (2002). Developmental Advising. Retrieved August 29, 2002, from National Clearinghouse for Academic Advising Web site: http://www.nacada.ksu.edu/ Clearinghouse/devadvising.html

Blustein, D. L., Judd, T. P., Krom, J., Viniar, B., Padilla, E., Wedemeyer, R., \& Williams, D. (1986, May). Identifying predictors of academic performance of community college students. Journal of College Student Personnel, 26, 242-249.

Bohr, D. H., Cias, G. W., \& Clayton, B. L. (1973). The effects of prescribed testing and personalized counseling on enrollment, attrition, and success of new students enrolled in reading courses at Sacramento City College. Unpublished doctoral practicum thesis, Nova University. (ERIC Document Reproduction Service No. ED099076)

Broadbridge, A. (1996). Academic advising — Traditional or developmental approaches?: Student perspectives [Electronic version]. British Journal of Guidance \& Counselling, 24(1), 97-113.

Chenault, S. (1996). The application of reliability and factor analyses in the development of an instrument to measure the attitudes of middle school, high school, and community college counselors concerning tech prep. (Doctoral dissertation, East Texas State University, 1996). Dissertation Abstracts International, 57, 2874.

Cloud, J. (2002, October 14). Who’s ready for colege? [sic] Time, 60, 63.

Cohen, A. M., \& Brawer, F. B. (1996). The American community college ( $3^{\text {rd }}$ ed.). San Francisco: Jossey-Bass.

Cohen, E. L. (1984). Assessment, advising, and early warning: Strategies for improving retention. Journal of College Reading and Learning, 17, 43-56.

Colby, A., \& Opp, R. (1987). Controversies surrounding developmental education in the community college. ERIC Digest. Los Angeles, CA: ERIC Clearinghouse for Junior Colleges. (ERIC Document Reproduction Service No. ED286557)

Coley, R. J. (2000). The American community college turns 100: A look at its students, programs, and prospects. Princeton, NJ: Educational Testing Service Policy Information Center, Research Division.

Creamer, D. G., \& Creamer, E. G. (1994). Practicing developmental advising: Theoretical contexts and functional applications. NACADA Journal, 14(2), 17-24.

Crockett, D. S. (1985). Academic advising. In L. Noel, R. Levitz, D. Saluri, \& Associates (Eds.), Increasing student retention: Effective programs and practices for reducing the dropout rate (pp. 244-263). San Francisco: Jossey-Bass. 
Crookston, B. B. (1994). A developmental view of academic advising as teaching. NACADA Journal, 14(2), 5-9. [Reprinted with permission from 1972 Journal of College Student Personnel, 13, 12-17.]

Culp, M. M. (1994). Looking backward/moving forward: Advising from a practitioner’s perspective. NACADA Journal, 14(2), 62-65.

Ender, S. C., \& Wilkie, C. J. (2000). Advising students with special needs. In V. N. Gordon, W. R. Habley, \& Associates (Eds.), Academic advising: A comprehensive handbook (pp. 118-143). San Francisco: Jossey-Bass.

Farren, P. J., \& Vowell, F. (2000). Model training programs. In V. N. Gordon, W. R. Habley, \& Associates (Eds.), Academic advising: A comprehensive handbook (pp. 308-323). San Francisco: Jossey-Bass.

Fielstein, L. L. (1994). Developmental versus prescriptive advising: Must it be one or the other? NACADA Journal, 14(2), 76-79.

Fielstein, L. L., \& Bush, L. K. (1998). Remedial students’ perceptions: Pre-college decision making, satisfaction with the freshman year, and self-perception of academic abilities. Journal of the First-Year Experience, 10(2), 41-56.

Fonte, R. (1997). Structured versus laissez-faire open access: Implementation of a proactive strategy. In J. M. Ignash (Ed.), New directions for community colleges, no. 100. Implementing effective policies for remedial and developmental education (pp. 43-52). San Francisco: Jossey-Bass.

Forrest, A. (1985). Creating conditions for student and institutional success. In L. Noel, R. Levitz, D. Saluri, \& Associates (Eds.), Increasing student retention: Effective programs and practices for reducing the dropout rate (pp. 62-77). San Francisco: Jossey-Bass.

Fraenkel, J. R., \& Wallen, N. E. (2000). How to design and evaluate research in education (4th ed.). Boston: McGraw-Hill.

Frank, K. S. (2000). Ethical considerations and obligations. In V. N. Gordon, W. R. Habley, \& Associates (Eds.), Academic advising: A comprehensive handbook (pp. 44-57). San Francisco: Jossey-Bass.

Frost, S. H. (1994). Advising alliances: Sharing responsibility for student success. NACADA Journal, 14(2), 54-58.

Frost, S. H. (1990, October). Educational improvement through academic advising: Advisor attitudes and practices that make a difference. Paper presented at the Annual Conference of the Southern Association for Institutional Research, Ft. Lauderdale, FL. (ERIC Document Reproduction Service No. ED327076) 
Frost, S. H. (1991). Academic advising for student success: A system of shared responsibility. (ASHE-ERIC Higher Education Report No. 3). Washington, DC: George Washington University.

Gardner, J. N. (1995). Perspectives on academic advising for first-year students: Present and future. In M. L. Upcraft \& G. L. Kramer, (Eds.), First-year academic advising: Patterns in the present, pathways to the future (National Academic Advising Association Monograph No. 18, pp. 163-169). Columbia, SC: University of South Carolina, National Resource Center for The Freshman Year Experience \& Student in Transition.

Garing, M. T. (1993). Intrusive academic advising. In M. C. King (Ed.), New directions for community colleges, no. 82. Academic advising: Organizing and delivering services for student success (pp. 97-103). San Francisco: Jossey-Bass.

Gerow, J. R., \& Murphy, D. P. (1980). The validity of the Nelson-Denny Reading Test as a predictor of performance in introductory psychology. Educational and Psychological Measurement, 40, 553-556.

Gordon, V. N. (1984). The undecided student: An academic and career advising challenge. Springfield, IL: Charles C. Thomas Publisher.

Grimes, S. K., \& David, C. K. (1999). Underprepared community college students: Implications of attitudinal and experiential differences [Electronic version]. Community College Review, 27(2), 73-93.

Habley, W. R. (1993). The organization and effectiveness of academic advising in community colleges. In M. C. King (Ed.), New directions for community colleges, no. 82. Academic advising: Organizing and delivering services for student success (pp. 33-45). San Francisco: Jossey-Bass.

Habley, W. R., \& Morales, R. H. (1998). Advising models: Goal achievement and program effectiveness. NACADA Journal, 18(1), 35-41.

Hadden, C. (1988, December). The placement process at Colorado Mountain College: Placement testing and the advising matrix. Paper presented at the Freshman Year Experience Conference, Columbia, SC. (ERIC Document Reproduction Service No. ED302298)

Hadden, C. (2000). The ironies of mandatory placement [Electronic version]. Community College of Research and Practice, 24, 823-838.

Hancock, D. R., (1996). Enhancing faculty motivation to advise students: An application of expectancy theory. NACADA Journal, 16(2), 11-15. 
Hays, K. L. (1994). Student assessment in the community college and the use of technology in testing. In G. A. Baker III (Ed.), A handbook of the community college in America: Its history, mission, and management (pp. 474-484). Westport, CT: Greenwood Press.

Helfgot, S. R. (1995, Spring). Counseling at the center: High tech, high touch. In S. R. Helfgot, \& M. M. Culp (Eds.), New directions for student services, no. 69. Promoting Student Success in the Community College (pp. 45-61). San Francisco: Jossey-Bass.

Herndon, J., Kasier, J. \& Creamer, D. (1996). Student preferences for advising style in community college environments. Journal of College Student Development, 37(6), 637648.

Higbee, J. L. (1996). Defining developmental education: A commentary [Electronic version]. In J. L. Higbee \& P. L. Dwinell (Eds.), Defining Developmental Education (NADE Monograph). Morrow: University of Georgia.

Hutchings, P. \& Reuben, E. (1988). Faculty voices on assessment: Expanding the conversation. Change, 20(4), 48-55.

Ikenberry, S. O., (1999). The truth about remedial education. Community College Journal, 69(5), 8.

Jesse, D. M., \& Gregory, W. L. (1987). A comparison of three attribution approaches to maintaining first year college GPA. Educational Research Quarterly, 11(1), 11-25.

Johnson, B. E. (1984). Valid testing model for admissions-placement. Community College Review, 12(2), 8-12.

Jones, C. H., Slate, J.R., Marini, I., \& DeWater, B. K. (1993). Academic skills and attitudes toward intelligence. Journal of College Student Development, 34, 422-424.

Jones, G. (1998, October). Faculty academic advising: An examination of students' and faculty members' perception of a first-year experience. Paper presented at National Conference on Student Retention, New Orleans, LA.

Jordan, P. (2000). Advising college students in the $21^{\text {st }}$ century. NACADA Journal, 20(2), 2130.

Joseph, S. (2000). The effect of developmental advising on community college students' retention rates. (Doctoral dissertation, University of Central Florida, 2000). Dissertation Abstracts International, 61, 470.

Kadar, R. S. (2001). A counseling liaison model of academic advising. Journal of College Counseling, 4, 174-178. 
King, M. C. (1993a). Academic advising, retention, and transfer. In M. C. King (Ed.), New directions for community colleges, no. 82. Academic advising: Organizing and delivering services for student success (pp. 21-31). San Francisco: Jossey-Bass.

King, M. C. (1993b). Advising models and delivery systems. In M. C. King (Ed.), New directions for community colleges, no. 82. Academic advising: Organizing and delivering services for student success (pp. 47-54). San Francisco: Jossey-Bass.

King, M. C. (1996). Academic advising: Clearing a path to student success. In J. N. Hankin, (Ed.), The community college: Opportunities and access for America's first year students (Monograph Series No. 19, pp. 115-121). Durham, SC: National Resource Center for the Freshman Year Experience and Students in Transition. (ERIC Document Reproduction Service No. ED393486)

King, M. C. (2002). Critical advising issues: Community college advising. Retrieved September 29, 2002, from NACADA National Clearinghouse for Academic Advising Web site: http://www.nacada.ksu.edu/Clearinghouse/comcollege.html

King, N. (2002). Critical advising issues: Reporting through academic vs. student affairs. Retrieved September 29, 2002, from NACADA National Clearinghouse for Academic Advising Web site: http://www.nacada.ksu.edu/Clearinghouse/acavstd.html

Kramer, G. L. (2000). Advising students at different educational levels. In V. N. Gordon, W. R. Habley, \& Associates (Eds.), Academic advising: A comprehensive handbook (pp. 84104). San Francisco: Jossey-Bass.

Kramer, L. G., \& Spencer, R. W. (1989). Academic advising. In M. L. Upcraft, J. N. Gardner, \& Associates (Eds.), The freshman year experience: Helping students survive and succeed in college (pp. 95-117). San Francisco: Jossey-Bass.

Levitz, R., \& Noel, L. (1989). Connecting students to institutions: Keys to retention and success. In M. L. Upcraft, J. N. Gardner, \& Associates (Eds.), The freshman year experience: Helping students survive and succeed in college (pp. 65-81). San Francisco: Jossey-Bass.

Laff, N. S. (1994). Reconsidering the developmental view of advising: Have we come a long way? NACADA Journal, 14(2), 46-49.

Lords, E. (2000). A revolution in academic advising at a Texas community college [Electronic version]. Chronicle of Higher Education, 47(4), A47-48.

Lowe, A., \& Toney, M. (2000). Academic advising: Views of the givers and takers. Journal of College Student Retention, 2(2), 93-108.

Mahon, P. G., \& Dannells, M. (1998). Advisors’ attitudes regarding transfer students. NACADA 
Journal, 18(2), 33-39.

Marsh, J. K. W. (2000). Institutional factors affecting academic persistence of underprepared community college freshmen. (Doctoral dissertation, University of Southern California, 2000). Dissertation Abstracts International, 62, 2052.

McAuliffe, G. J., \& Strand, R. F. (1994). Advising from a constructive developmental perspective. NACADA Journal, 14(1), 25-31.

McCabe, R. H. (2000). No one to waste: A report to public decision-makers and community college leaders. Washington, DC: Community College Press.

McCollum, V. J. C. (1998). Career advising: A developmental approach. NACADA Journal, 18(1), 15-19.

McMillan, J. B. (1993). Making access meaningful: Effects of an early contact program on community college student success. (Doctoral dissertation, College of William and Mary, 1993). Dissertation Abstracts International, 55, 2033.

Melichar, B. E. (1994). Instructors' attitudes toward nontraditional students positive, study shows. Adult Learning, 6(1), 27-28.

Mercer, B. (1995). A comparison of students who follow mathematics advisement recommendations and students who did not at Rochester community college. Unpublished doctoral practicum thesis, Nova Southeastern University. (ERIC Document Reproduction Service No. ED400014)

Miller, M. A., \& Alberts, B. (1994). Developmental advising: Where teaching and learning intersect. NACADA Journal, 14(2), 43-45.

Mitchell, T. R. (1989, April). Daring to demand: Mandatory recommendation works! Paper presented to the faculty of St. Philip's Community College, San Antonio, TX. (ERIC Document Reproduction Service No. ED305177)

Molina, A. \& Abelman, R. (2000). Style over substance in interventions for at-risk students: The impact of intrusiveness. NACADA Journal, 20(2), 5-15.

Moore, W. Jr., \& Carpenter, L. C. (1985). Academically underprepared students. In L. Noel, R. Levitz, D. Saluri, \& Associates (Eds.), Increasing student retention: Effective programs and practices for reducing the dropout rate (pp. 95-115). San Francisco: Jossey-Bass.

Morante, E. A. (1989). Selecting tests and placing students. Journal of Developmental Education, 13(2), 2-4, 6.

Morante, E. A. (2001, October). Evaluating placement decisions. Paper presented at the 2001 Research in Developmental Education Conference, Charlotte, NC. 
NACADA (1995). Statement of core values of academic advising. In M. L. Upcraft \& G. L. Kramer, (Eds.), First-year academic advising: Patterns in the present, pathways to the future (National Academic Advising Association Monograph No. 18, pp. 173-178). Columbia, SC: University of South Carolina, National Resource Center for The Freshman Year Experience \& Student in Transition.

NACADA Council for the Advancement of Standards (1997). CAS Standards \& Guidelines. Retrieved August 29, 2002, from National Academic Advising Association Web site: http://www.nacada.ksu.edu/Profres/standard.htm

NADE Executive Board. (1998). Need for mandatory academic testing and placement of students in appropriate college courses. Resolution Approved March 1, 1998; Revised July 31, 1998. Retrieved November 21, 2001, from National Association of Developmental Education Web site: http://www.umkc.edu/cad/nade/ nadedocs/pstsp198.htm

Napoli, A., \& Wortman, P. (1995). Validating college-level reading placement test standards. Journal of Applied Research in the Community College, 2(2), 143-151.

Neal, P. J. (1995). Student perceptions of orientation, assessment, and advisement/counseling component activities in selected California community colleges. (Doctoral dissertation, University of La Verne, 1995). Dissertation Abstracts International, 60, 74.

NVCC Office of Institutional Research (2000). Evaluation of NVCC Counseling and Career Center services. (Research Report No. 12-00). Annandale, VA: Northern Virginia Community College. (ERIC Document Reproduction Service No. ED453877)

O’Banion, T. (1994a). An academic advising model. NACADA Journal, 14(2), 10-16. [Reprinted with permission from 1972 Junior College Journal, 42, 62, 64, 66-69.]

O’Banion, T. (1994b). Retrospect and prospect. NACADA Journal, 14(2), 117-119.

Onofrio, A. (1988). A student development model for academic advising [Descriptive report]. Cicero, IL: Morton College Counseling Center. (ERIC Document Reproduction Service No. ED300095)

Palmer, J. C. (1994). Faculty practices and attitudes as teachers and scholars: A review of research. In G. A. Baker III (Ed.), A handbook of the community college in America: Its history, mission, and management (pp. 423-435). Westport, CT: Greenwood Press.

Parnell, D. (1990). Dateline 2000: The new higher education agenda. Washington, DC: Community College Press.

Pascarella, E. T. (1980). Student-faculty informal contact and college outcomes. Review of Educational Research, 50(4), 545-595. 
Perry, J. C. (2001). Faculty Advising Survey Results, 1996 through 2001 [Research report]. Appleton, WI: Fox Valley Technical College. (ERIC Document Reproduction Service No. ED457882)

Peterson, L., \& McDonough, E. (1985). Developmental advising of undeclared students using an integrated model of student growth. NACADA, 5(1), 61-69.

Polson, C. J. (1994). Developmental advising for nontraditional students. Adult Learning, 6(1), 21-22, 28.

Rada, J. (2000, November 2). Allegany county graduates behind: Most respond well to refresher courses once enrolled in college. Cumberland Times-News, pp. A1, A7.

Ramos, B. (1994). O’Banion Revisited: Now more than ever. NACADA Journal, 14(2), 89-91.

Rankey, R. (1994). Reflections in a rearview mirror-Revisiting the O’Banion model. NACADA Journal, 14(2), 39-42.

Raushi, T. M. (1993). Developmental academic advising. In M. C. King (Ed.), New directions for community colleges, no. 82. Academic advising: Organizing and delivering services for student success (pp. 5-19). San Francisco: Jossey-Bass.

Rendon, L. (2000). Fulfilling the promise of access and opportunity: Collaborative community colleges for the $21^{\text {st }}$ century. New Expeditions Issues Papers. Washington, DC: American Association of Community Colleges.

Rhoads, R. A., \& Valadez, J. R. (1996). Democracy, Multiculturalism, and the Community College: A Critical Perspective. New York: Garland Publishing.

Rooney, M. (1994). Back to the future: Crookston and O’Banion revisited. NACADA Journal, 14(2), 35-38.

Roueche, J. E. \& Roueche, S. D. (1996). Those who tempt fate and those who advise them: Designing strategies for serving underprepared students. In Hankin, J. N. (Ed.), The community college: Opportunities and access for America's first year students (Monograph Series No. 19, pp. 77-84). Durham, SC: National Resource Center for the Freshman Year Experience and Students in Transition. (ERIC Document Reproduction Service No. ED393486)

Roueche, J. E., \& Roueche, S. D. (1999a). High stakes, high performance: Making remedial education work. Washington, DC: Community College Press.

Roueche, J. E., \& Roueche, S. D. (1999b). Keeping the promise: Remedial education revisited. Community College Journal, 6(5), 12, 14-18. 
Rounds, J. C., \& Anderson, D. (1985). Placement in remedial college classes: Required vs. recommended. Community College Review, 13(1), 21-27.

Saluri, D. (1985). Case studies and successful programs. In L. Noel, R. Levitz, D. Saluri, \& Associates (Eds.), Increasing student retention: Effective programs and practices for reducing the dropout rate (pp. 402-447). San Francisco: Jossey-Bass.

Sanders, J. A., \& Wiseman, R. L. (2000, November). Development of a scale for the student assessment of academic advisors. Paper presented at the Annual Meeting of the National Communication Association, Seattle, WA. (ERIC Document Reproduction Service No. ED453284)

Sanford-Harris, J. L. (1993). Advising the two-year student: Considerations and strategies. In M. C. King (Ed.), New directions for community colleges, no. 82. Academic advising: Organizing and delivering services for student success (pp. 75-82). San Francisco: Jossey-Bass.

Santa Rita, E. D. Jr. (1997). Bronx community college’s developmental academic advising center: An evolving model for the millennium [Descriptive report]. New York: Bronx Community College. (ERIC Document Reproduction Service No. ED416913)

Sawyer, R. (1996). Decision theory models for validating course placement tests. Journal of Educational Measurement, 33, 271-290.

Schein, H. K. \& Laff, N. S. (1997). Working with undecided students: A hands-on strategy. NACADA Journal, 17(1), 42-48.

Severy, L. J. (1994). Rating scales for the evaluation of academic advisors. NACADA Journal, 14(2), 121-129.

Shaffer, L. S. (1997). A human capital approach to academic advising. NACADA Journal, 17(1), 5-11.

Shaffer, L. S. (1998). Maximizing human capital by developing multicultural competence. NACADA Journal, 18(2), 21-27.

Shelor, M. D., \& Bradley, J. M. (1999). Case studies in support of multiple criteria for developmental reading placement. Journal of College Reading and Learning, 30(1), 1733.

Shults, C. (2000). Remedial education: Practices and policies in community colleges (Research Brief No. AACC-RB-00-2). Annapolis Junction, MD: Community College Press.

Smittle, P. (1993). Computer adaptive testing: A new era. Journal of Developmental Education, 17(1), 8-10, 12. 
Spann, N. G., Spann, M. G., \& Confer, L. S. (1995). Advising underprepared first-year students. In M. L. Upcraft \& G. L. Kramer, (Eds.), First-year academic advising: Patterns in the present, pathways to the future (National Academic Advising Association Monograph No. 18, pp. 101-110). Columbia, SC: University of South Carolina, National Resource Center for The Freshman Year Experience \& Student in Transition.

Spickelmier, D. O. (1973). Community college faculty attitudes toward educationally disadvantaged students. California Journal of Educational Research, 24(4), 169-174.

Spiers, C. E. (2000). Toward a practical theory of academic advising: A two-year model. (Doctoral dissertation, Ohio University, 2000). Dissertation Abstracts International, 61, 2199.

Strommer, D. W. (1995). Advising special populations of students. In A. G. Reinarz, \& E. R. White (Eds.), New directions for teaching and learning, no. 62. Teaching through academic advising: A faculty perspective (pp. 25-34). San Francisco: Jossey-Bass.

Sum, A., Kirsch, I., \& Taggart, R. (2002, February). The twin challenges of mediocrity and inequality: Literacy in the U.S. from an international perspective (Policy Information Report). Princeton, NJ: Policy Information Center, Educational Testing Service.

Tinto, V. (1987). Leaving college: Rethinking the causes and cures of student attrition. Chicago: University of Chicago Press.

Tinto, V. (1993). Leaving college: Rethinking the causes and cures of student attrition (2 ${ }^{\text {nd }}$ ed.). Chicago: University of Chicago Press.

Toy, T. J. (1985). Increasing faculty involvement in retention efforts. In L. Noel, R. Levitz, D. Saluri, \& Associates (Eds.), Increasing student retention: Effective programs and practices for reducing the dropout rate (pp. 383-401). San Francisco: Jossey-Bass.

Upcraft, M. L., \& Stephens, P. S. (2000). Academic advising and today’s changing students. In V. N. Gordon, W. R. Habley, \& Associates (Eds.), Academic advising: A comprehensive handbook (pp. 73-83). San Francisco: Jossey-Bass.

Utterback, J. (1998). Closing the door: A critical review of forced academic placement. Journal of College Reading and Learning, 29(1), 48-58.

Valverde, L. A. (1985). Low-income students. In L. Noel, R. Levitz, D. Saluri, \& Associates (Eds.), Increasing student retention: Effective programs and practices for reducing the dropout rate (pp. 78-94). San Francisco: Jossey-Bass.

Wambach, C., \& Brothen, T. (1990). An alternative to the prediction-placement model. Journal of Developmental Education, 13(3), 14-15, 24-26. 
Weston, P. S. (1994). The effects of advisor training on retention, student satisfaction with advising services, and advisor satisfaction with the role of advising. (Doctoral dissertation, Clemson University, 1994). Dissertation Abstracts International, 56, 3426.

White, E. R. (2000). Developing mission, goals, and objectives for the advising program. In V. N. Gordon, W. R. Habley, \& Associates (Eds.), Academic advising: A comprehensive handbook (pp. 180-191). San Francisco: Jossey-Bass.

Winston, R. B. \& Sandor, J.A. (1984). Evaluation academic advising: A preliminary manual for the Academic Advising Inventory. Athens, GA: University of Georgia, Student Development Associates, Inc. 


\title{
APPENDIX A: Letter to Vice President of Instructional Affairs Seeking Approval to Conduct Research
}

\author{
Dr. Gene Hall \\ Vice President of Academic Affairs \\ Allegany College of Maryland \\ 12401 Willowbrook Road, SE \\ Cumberland, MD 21502
}

February 26, 2003

Dear Dr. Hall:

As you know, I am working on my doctorate in higher education leadership at West Virginia University. My dissertation research involves examining the relationship between advisors' attitudes toward developmental placement and their advisees' academic performance. I seek your permission to conduct the research at Allegany College of Maryland.

The research will involve sending a survey to academic advisors, administering a questionnaire to students enrolled in developmental courses, and accessing student data from institutional records. For statistical data analysis, I will need to match each advisor's responses on the survey to the grades and course completion rates of the students they advise. However, advisor/advisee data will be linked by code number only, and no identifying information will ever be revealed. All data analysis will be performed and reported only in aggregate form. In my dissertation and in all future publications of the research findings, Allegany College of Maryland will be referred to by pseudonym only, unless you provide explicit permission for me to refer to the college by name.

Results from this study will be used to help our college and other community colleges make informed decisions on how best to serve underprepared students as they enroll in college for the first time.

Thank for your support.

Sincerely,

June E. Bracken

Cc: Dr. Alexander, College President 
March 4, 2003

Dear Ms. Bracken:

I hereby grant you permission to conduct your dissertation research at Allegany College of Maryland during the 2003-2004 academic year, provided that you adhere to the research methods described in your proposal. You may survey faculty and students, and you may access student data from institutional records as long as strict confidentiality of all information is maintained. You may not refer to the College by name unless I explicitly grant you that permission in writing at a later time.

I wish you the best in this endeavor, and look forward to reviewing the research findings.

Sincerely.

Gene Hall, Vice President Instructional Affairs 
October 2, 2003

Dear Colleagues:

As most of you know, I am working on my doctorate in higher education leadership at West Virginia University. My dissertation research involves examining the relationship between 2advisors' attitudes toward developmental placement and advisees' academic performance. I have Dr. Hall's permission to conduct the research here at Allegany College of Maryland. I would appreciate your assistance in this project by filling out the enclosed Advisor Attitude Survey by October 17.

Please note that your participation is entirely voluntary, and you do not have to respond to every item. Your responses will remain anonymous.

For statistical analysis of data, I will need to match each advisor's responses on this survey to the grades and course completion rates of the students they advise. We're all aware that students don't always see their assigned advisor the first time they register for classes. Therefore, rather than matching students with their advisor of record, I will check the advising grid of each individual student to determine who actually signed approval, and the person who signed the advising grid for first-time course registration will be deemed the advisor in data analysis.

You may notice a code number on the top right hand corner of the survey. This code number will be used to assure confidentiality of responses. Advisor/advisee data will be linked by code number only, and no identifying information will ever be revealed. All data analysis will be performed and reported only in aggregate form, so responses will be untraceable to individuals, or even to departments or programs.

Results from this study will be used to help our college and other community colleges make informed decisions on how best to serve underprepared students as they enroll in college for the first time.

The survey should take approximately ten minutes to complete. When you finish filling out the three-page survey, please seal it in the enclosed addressed envelope and return it to me through campus mail.

Thank for your support and cooperation.

Sincerely,

June E. Bracken 
December 8, 2003

Dear [Cathy]:

As part of my doctoral research, I sent out a survey about advising back in October. My dissertation research involves examining the relationship between advisors' attitudes toward developmental placement and their underprepared advisees' academic performance. Your participation in this project is voluntary, so you may have chosen to forego filling out the survey. However, if you simply forgot or didn't get a chance to fill out the survey before the listed due date, then I would appreciate your assistance in this project by filling out the enclosed Advisor Attitude Survey by Friday, December 19, 2003.

As I stated in my first letter, your answers will be kept completely confidential. The code number on the top right hand corner of the survey is being used to assure confidentiality of responses. Advisor/advisee data will be linked only by code number, and no identifying information will ever be revealed. All data analysis will be performed and reported only in aggregate form, so responses will be untraceable to individuals, or even to departments or programs.

Results from this study will be used to help our college and other community colleges make informed decisions on how best to serve underprepared students as they enroll in college for the first time. I will send a summary of the results to all participants.

The survey should take approximately ten minutes to complete. When you finish filling out the three-page survey, please seal it in the enclosed envelope and return it to me through campus mail.

Thank for your support and cooperation.

Sincerely,

June E. Bracken

Doctoral Candidate 


\section{APPENDIX D: Script/Cover Letter for Introducing and Administering the Student Advising Questionnaire}

November 2003

Hello.

My name is June Bracken, and I'm a doctoral student at West Virginia University. I'm here to ask your help with an important research project concerning academic advising. This research will result in my dissertation, one of the requirements for the doctoral degree. By gathering as much information as I can from students, I hope to provide a way for advisors to do a better job helping new students select the courses that are best for them.

The survey asks questions about the person who helped you register for classes this semester, even if it wasn't your assigned advisor. It asks whether the things that person said or did helped you get settled into the right classes. Your answers on the attached questionnaire will be kept completely confidential and will be used for statistical reporting only. That means that your answers will be combined with those of many other students to see if we can draw conclusions about what activities are most helpful to new students. Please read the directions to each section carefully, and then read each question carefully and answer based upon your own personal experience.

Completing this survey will have no effect on your grade in this course, and your teacher won't ever see your answers. As I said, what you write down will be kept confidential. The questionnaire will take approximately 10 minutes or less to complete. All of the questions are important, but you may leave a question blank if you don't feel comfortable answering it.

Please don't put your name on the paper. When you finish answering all the questions, please put it the enveloped addressed to June Bracken and return it to your teacher.

I want to thank you for your contribution to this important research. If you have any questions about the project, please feel free to contact me. Again, my name is June Bracken, and my phone number is 301-784-5112, or you can visit me in the Humanities Building, room 56, at 3:00-4:00 any day this week.

Thank you for your time. 


\section{APPENDIX E: Cover Letter to Faculty for Administering the Student Advising Questionnaire}

November 2003

\section{Dear [Norm],}

I'm approaching the final stage of my doctoral work at West Virginia University, and I need your help with data collection. I'm asking first-time students to fill out a survey about the advising they received when they first entered ACM. The research is for my dissertation, but students will benefit because results will be used to improve the advising system at this college. Enclosed you will find envelopes addressed to several of your students. Would you please hand out the surveys and provide students with a brief explanation something like this one:

A colleague of mine is doing research on the advising system at this college and she would like your help. There is an explanation of this important project on the back of your envelope. She is trying to get feedback from almost 800 first-time students on the advising they received when they first came to the college. The survey will only take you about ten minutes to complete, and the results will be used to help improve advising at this college. Please answer the survey questions about the person who helped you sign up for classes, even if that person wasn't your assigned advisor. When you're done, you can give the survey back to me and I'll get it back to her. Thank you.

Norm, any encouragement you can give students to fill out the survey, whether it be a couple of bonus points or just a simple reminder, will help increase the return rate. Thank you so much for your help. 
APPENDIX F:

Advisor Attitude Survey 


\section{Advisor Attitude Survey}

(1) Please rate how strongly you agree or disagree with the following statements about developmental placement and prerequisites.

Example: (4) (2) (1)

\begin{tabular}{|c|c|c|c|c|c|}
\hline & & $\begin{array}{l}\text { Strongly } \\
\text { Agree }\end{array}$ & Agree & Disagree & $\begin{array}{l}\text { Strongly } \\
\text { Disagree }\end{array}$ \\
\hline a. & $\begin{array}{l}\text { Prerequisites are requirements that need to be completed before taking } \\
\text { a course }\end{array}$ & (4) & (3) & (2) & (1) \\
\hline b. & $\begin{array}{l}\text { Admitting underprepared students into college classes leads to lower } \\
\text { standards }\end{array}$ & (4) & (3) & (2) & (1) \\
\hline C. & $\begin{array}{l}\text { I am knowledgeable about this College's developmental placement } \\
\text { policies }\end{array}$ & (4) & (3) & (2) & (1) \\
\hline d. & $\begin{array}{l}\text { I get frustrated when my advisees are prevented from taking courses } \\
\text { they need because they have to take a developmental course first }\end{array}$ & (4) & (3) & (2) & (1) \\
\hline e. & Mandatory placement in developmental courses is discriminatory & (4) & (3) & (2) & (1) \\
\hline f. & $\begin{array}{l}\text { Requiring students to complete developmental requirements will lead to } \\
\text { greater success in the long run }\end{array}$ & (4) & (3) & (2) & (1) \\
\hline g. & It is important to help students set realistic academic goals & (4) & (3) & (2) & (1) \\
\hline h. & $\begin{array}{l}\text { Knowing a student's specific placement scores as well as the course } \\
\text { placement recommendation is useful when advising }\end{array}$ & (4) & (3) & (2) & (1) \\
\hline i. & If students are "over their heads" in a class, it's up to them to find help & (4) & (3) & (2) & (1) \\
\hline j. & $\begin{array}{l}\text { This school's placement assessment instrument provides a fair } \\
\text { measure of students' ability }\end{array}$ & (4) & (3) & (2) & (1) \\
\hline k. & $\begin{array}{l}\text { Helping my students learn to make informed decisions about what } \\
\text { courses to take is an important part of my role as advisor }\end{array}$ & (4) & (3) & (2) & (1) \\
\hline I. & $\begin{array}{l}\text { Students will perform better if they understand why they were placed in } \\
\text { a developmental course }\end{array}$ & (4) & (3) & (2) & (1) \\
\hline $\mathrm{m}$. & Students who need to take developmental courses are "behind" & (4) & (3) & (2) & (1) \\
\hline $\mathrm{n}$. & $\begin{array}{l}\text { It is important to have some understanding of an advisee's learning } \\
\text { difficulties }\end{array}$ & (4) & (3) & (2) & (1) \\
\hline 0. & $\begin{array}{l}\text { Prerequisites are recommendations that help students make informed } \\
\text { choices about what courses to take }\end{array}$ & (4) & (3) & (2) & (1) \\
\hline p. & $\begin{array}{l}\text { Completing developmental math requirements improves students' chance } \\
\text { for academic success in classes that require mathematical skill or reasoning }\end{array}$ & (4) & (3) & (2) & (1) \\
\hline q. & $\begin{array}{l}\text { Completing developmental writing requirements improves students' } \\
\text { chance for academic success in classes that require much writing }\end{array}$ & (4) & (3) & (2) & (1) \\
\hline r. & $\begin{array}{l}\text { Completing developmental reading requirements improves students' } \\
\text { chance for academic success in classes that require a great deal of } \\
\text { reading }\end{array}$ & (4) & (3) & (2) & (1) \\
\hline s. & I wish more was done at this school to enforce prerequisites & (4) & (3) & (2) & (1) \\
\hline t. & I am knowledgeable about this college's Academic Regulations & (4) & (3) & (2) & (1) \\
\hline
\end{tabular}


2 Please rate the importance, in terms of the degree of influence it might have on student success, of performing each of the following activities when registering first-time college students.

Example: (4) - (2) (1)

\begin{tabular}{|c|c|c|c|c|c|}
\hline \multicolumn{2}{|r|}{ Advising Activities with First-time Students } & \multirow{2}{*}{$\begin{array}{c}\begin{array}{c}\text { Vitally } \\
\text { Important }\end{array} \\
\text { (4) }\end{array}$} & \multirow{2}{*}{$\begin{array}{c}\text { Helpful } \\
\text { (3) }\end{array}$} & \multirow{2}{*}{$\begin{array}{c}\text { Trivial } \\
\text { (2) }\end{array}$} & \multirow{2}{*}{$\begin{array}{c}\begin{array}{c}\text { Counter } \\
\text { Productive }\end{array} \\
\text { (1) }\end{array}$} \\
\hline a. & Make a referral to other campus services & & & & \\
\hline b. & Explain registration procedures & (4) & (3) & (2) & (1) \\
\hline c. & Explain to students why they need to take developmental courses & (4) & (3) & (2) & (1) \\
\hline d. & $\begin{array}{l}\text { Spend approximately } 30 \text { minutes or more helping students plan } \\
\text { out what to take the next few semesters }\end{array}$ & (4) & (3) & (2) & (1) \\
\hline e. & Describe the differences between two or more course options & (4) & (3) & (2) & (1) \\
\hline f. & Ask questions about why they picked their major & (4) & (3) & (2) & (1) \\
\hline g. & Explain the possible ways to waive a developmental requirement & (4) & (3) & (2) & (1) \\
\hline h. & Ask what time of day they usually concentrate best & (4) & (3) & (2) & (1) \\
\hline i. & $\begin{array}{l}\text { Explain the importance of having the basic skills necessary for } \\
\text { college success }\end{array}$ & (4) & (3) & (2) & (1) \\
\hline j. & $\begin{array}{l}\text { Give examples or statistics of how well previous students have } \\
\text { performed after completing their developmental requirements }\end{array}$ & (4) & (3) & (2) & (1) \\
\hline $\mathrm{k}$. & $\begin{array}{l}\text { Reassure students that there is no shame in taking brush-up } \\
\text { courses }\end{array}$ & (4) & (3) & (2) & (1) \\
\hline $\mathrm{I}$. & Explain course requirements in their major & (4) & (3) & (2) & (1) \\
\hline m. & $\begin{array}{l}\text { Give them an idea of what kinds of learning activities to expect } \\
\text { from particular classes }\end{array}$ & (4) & (3) & (2) & (1) \\
\hline $\mathrm{n}$. & $\begin{array}{l}\text { Encourage students to check in with you often during the } \\
\text { semester }\end{array}$ & (4) & (3) & (2) & (1) \\
\hline 0. & $\begin{array}{l}\text { Suggest they get a tutor at the start of the semester if their skills } \\
\text { are weak }\end{array}$ & (4) & (3) & (2) & (1) \\
\hline p. & Help them make a long-range plan for finishing their degree & (4) & (3) & (2) & (1) \\
\hline q. & $\begin{array}{l}\text { Encourage students to get involved in study groups with other } \\
\text { students }\end{array}$ & (4) & (3) & (2) & (1) \\
\hline r. & Talk to them about how to manage time while in college & (4) & (3) & (2) & (1) \\
\hline s. & Ask them about their past academic performance & (4) & (3) & (2) & (1) \\
\hline $\mathrm{t}$. & Discuss effective study skills & (4) & (3) & (2) & (1) \\
\hline u. & Ask what they hope to learn in their major & (4) & (3) & (2) & (1) \\
\hline
\end{tabular}




\begin{tabular}{|c|c|c|c|c|c|}
\hline \multicolumn{2}{|r|}{ Advising Activities with First-time Students (continued) } & \multirow{2}{*}{$\frac{\begin{array}{c}\text { Vitally } \\
\text { Important }\end{array}}{\text { (4) }}$} & \multirow{2}{*}{$\begin{array}{c}\text { Helpful } \\
\text { (3) }\end{array}$} & \multirow{2}{*}{$\begin{array}{c}\text { Trivial } \\
\text { (2) }\end{array}$} & \multirow{2}{*}{$\begin{array}{c}\begin{array}{c}\text { Counter } \\
\text { Productive }\end{array} \\
\text { (1) }\end{array}$} \\
\hline V. & Help students explore career options & & & & \\
\hline W. & $\begin{array}{l}\text { Encourage them to assume an active role in planning their } \\
\text { academic program }\end{array}$ & (4) & (3) & (2) & (1) \\
\hline $\mathrm{x}$. & $\begin{array}{l}\text { Suggest the student talk with the course instructor before classes } \\
\text { begin }\end{array}$ & (4) & (3) & (2) & (1) \\
\hline$y$. & Encourage the student to become involved with outside activities & (4) & (3) & (2) & (1) \\
\hline $\mathrm{Z}$. & $\begin{array}{l}\text { Talk about setting priorities and balancing school, job, and family } \\
\text { responsibilities }\end{array}$ & (4) & (3) & (2) & (1) \\
\hline aa. & $\begin{array}{l}\text { Explain that it might take longer than two years to finish a "two- } \\
\text { year" associate degree }\end{array}$ & (4) & (3) & (2) & (1) \\
\hline$b b$. & $\begin{array}{l}\text { Try to match a student's learning style with instructors' teaching } \\
\text { styles when selecting classes }\end{array}$ & (4) & (3) & (2) & (1) \\
\hline cc. & Stress that school needs to be a top priority & (4) & (3) & (2) & (1) \\
\hline dd. & Ask whether and how many hours students work & (4) & (3) & (2) & (1) \\
\hline
\end{tabular}

(3) Please answer the following questions about yourself.

a. What is your gender? Male Female

b. How many years have you served as an academic advisor at the college level?

c. When you were in college, did you ever take any developmental courses in English, reading, or mathematics? Yes No

Thank you for taking the time to complete this survey. Please return the survey through campus mail in the enclosed envelope. 


\section{ATTITUDES TOWARD UNDERPREPARED STUDENTS}

\section{TRADITIONAL*}

1b. Admitting underprepared students into college classes leads to lower standards

1i. If students are "over their heads" in a class, it's up to them to find help

1m. Students who need to take developmental courses are "behind"

\section{INTERACTIONAL}

1g. It is important to help students set realistic academic goals

1h. Knowing a student's placement scores is useful when advising

$1 \mathrm{k}$. One of the most valuable tools I can offer my advisees is to help them learn to make informed decisions about what courses to take

11. Students will perform better if they understand why they were placed in a developmental course

1n. It is important to have some understanding of an advisee's learning difficulties

\section{ATTITUDES TOWARD DEVELOPMENTAL PLACEMENT POLICY}

\section{LAISSEZ-FAIRE *}

1d. I get frustrated when my advisees are prevented from taking courses they need because they have to take a developmental course first

1e. Mandatory placement in developmental courses is discriminatory

10. Prerequisites are recommendations intended to help students make informed choices about what courses to take

* Items categorized as Traditional or Laissez-Faire will be reverse scored.

\section{STRUCTURED}

1a. Prerequisites are requirements that need to be completed before taking a course

1c. I am knowledgeable about this College's developmental placement policies

1f. Requiring students to complete developmental requirements will lead to greater success in the long run

1j. This school's placement assessment instrument provides a fair measure of students' ability

1p. Completing developmental math requirements improves students' chance for academic success

1q. Completing developmental writing requirements improves students' chance for academic success

1r. Completing developmental reading requirements improves students' chance for academic success

1s. I wish more was done at this school to enforce prerequisites

1t. I am knowledgeable about this college's Academic Regulations 
Appendix H: Item Categorization Matrix for Part 2 of the Advisor Attitude Survey

\begin{tabular}{|c|c|}
\hline \multicolumn{2}{|r|}{ Advising Activities Unique to the Prescriptive Model } \\
\hline 2cc. & Stress that school needs to be a top priority \\
\hline & Advising Activities Consistent to Both the Prescriptive and Developmental Models \\
\hline $2 \mathrm{a}$. & Make a referral to other campus services \\
\hline $2 \mathrm{~b}$. & Explain registration procedures \\
\hline $2 g$. & Explain the possible ways to waive a developmental requirement \\
\hline 2l. & Explain course requirements in their major \\
\hline 2aa. & Explain that it might take longer than two years to finish a "two-year" associate degree \\
\hline \multicolumn{2}{|r|}{ Advising Activities Unique to the Developmental Model } \\
\hline 2c. & Explain to students why they need to take a developmental course \\
\hline $2 \mathrm{~d}$. & Spend approximately 30 minutes or more helping them plan out what to take the next few semesters \\
\hline $2 \mathrm{e}$. & Describe the differences between two or more course options \\
\hline $2 f$. & Ask them questions about why they picked their major \\
\hline $2 \mathrm{~h}$. & Ask what time of day they usually concentrate best \\
\hline $2 \mathrm{i}$. & Explain the importance of having the basic skills necessary for college success \\
\hline $2 \mathrm{j}$. & $\begin{array}{l}\text { Give examples or statistics of how well previous students have performed after completing their } \\
\text { developmental requirements }\end{array}$ \\
\hline $2 \mathrm{k}$. & Reassure students that there is no shame in taking brush-up courses \\
\hline $2 m$. & Give them an idea of what kinds of learning activities to expect from particular classes \\
\hline $2 n$. & Encourage students to check in with you often during the semester \\
\hline 20. & Suggest they get a tutor at the start of the semester if their skills are weak \\
\hline $2 p$. & Help them make a long-range plan for finishing their degree \\
\hline 2q. & Encourage students to get involved with study groups \\
\hline $2 r$. & Talk to them about how to manage time while in college \\
\hline $2 \mathrm{~s}$. & Ask them about their past academic performance \\
\hline $2 \mathrm{t}$. & Discuss effective study skills \\
\hline $2 u$. & Ask what students hope to learn in their major \\
\hline $2 \mathrm{v}$. & Help students explore career options \\
\hline $2 \mathrm{w}$. & Encourage them to assume an active role in planning their academic program \\
\hline $2 x$ & Suggest the student talk with the course instructor before classes begin \\
\hline $2 y$. & Explain general college procedures, such as how to get a library card or how to drop a class \\
\hline $2 z$. & Talk about setting priorities and balancing school, job, and family responsibilities \\
\hline $2 b b$. & Try to match a student's learning style with instructors' teaching styles when selecting classes \\
\hline $2 \mathrm{dd}$. & Ask whether and how many hours students work \\
\hline
\end{tabular}




\section{APPENDIX I}

Student Advising Questionnaire 


\section{Student Advising Questionnaire}

(1) When you first registered for fall semester, who helped you make your schedule and sign up for classes? (In this survey, we'll call that person your advisor).

My assigned advisor

Someone in the Admissions Office

A faculty member from my major

My coach

Someone else:

If you remember the person's name, who was it?

(2) While you were registering, could you tell how your advisor felt about different courses and issues? Please rate how strongly you think your advisor feels or thinks about each statement.

Example: (4) (2) (1)

\begin{tabular}{|c|c|c|c|c|}
\hline I think my advisor: & $\begin{array}{l}\text { Strongly } \\
\text { Agree }\end{array}$ & Agree & Disagree & $\begin{array}{l}\text { Strongly } \\
\text { Disagree }\end{array}$ \\
\hline $\begin{array}{l}\text { a. Thought that the developmental courses would be } \\
\text { good for me }\end{array}$ & (4) & (3) & (2) & (1) \\
\hline $\begin{array}{l}\text { b. Didn't think I should have to take any developmental } \\
\text { courses }\end{array}$ & (4) & (3) & (2) & (1) \\
\hline $\begin{array}{l}\text { c. Wanted me to sign up for as many credits as possible } \\
\text { first semester }\end{array}$ & (4) & (3) & (2) & (1) \\
\hline $\begin{array}{l}\text { d. Wanted me to understand how brushing-up on my } \\
\text { skills would help me }\end{array}$ & (4) & (3) & (2) & (1) \\
\hline $\begin{array}{l}\text { e. Acted like I should already be ready to handle college } \\
\text { courses }\end{array}$ & (4) & (3) & (2) & (1) \\
\hline $\begin{array}{l}\text { f. Tried to balance my schedule with easy and hard } \\
\text { courses }\end{array}$ & (4) & (3) & (2) & (1) \\
\hline g. Cared whether I was satisfied with my schedule & (4) & (3) & (2) & (1) \\
\hline h. Wanted to help me do the best I could in school & (4) & (3) & (2) & (1) \\
\hline $\begin{array}{l}\text { i. Thought I should make school my number one priority, } \\
\text { no matter what }\end{array}$ & (4) & (3) & (2) & (1) \\
\hline j. Understood my goals and priorities for school & (4) & (3) & (2) & (1) \\
\hline
\end{tabular}


(3) According to your results on the College placement assessment, you were required to take at least one developmental course. For each course listed, please indicate whether you were told that you were required to take it and how helpful you think taking the course would be.

\begin{tabular}{llcccc}
\hline & $\begin{array}{c}\text { Are you required to } \\
\text { take the course? }\end{array}$ & \multicolumn{4}{c}{$\begin{array}{c}\text { much do you think you will benefit } \\
\text { from taking the course? }\end{array}$} \\
& $\square$ A Ges $\square$ No & (4) & (3) & (2) & (1) \\
\hline Math 80 Arithmetic & Quite A Lot & A Litle & Not at All \\
\hline Math 90 (or Math 96) Beginning Algebra & $\square$ Yes $\square$ No & (4) & (3) & (2) & (1) \\
\hline Math 93 Intermediate Algebra & $\square$ Yes $\square$ No & (4) & (3) & (2) & (1) \\
\hline English 90 Developmental English I & $\square$ Yes $\square$ No & (4) & (3) & (2) & (1) \\
\hline English 93 Developmental English II & $\square$ Yes $\square$ No & (4) & (3) & (2) & (1) \\
\hline Reading 90 Comprehensive Reading I & $\square$ Yes $\square$ No & (4) & (3) & (2) & (1) \\
\hline Reading 93 Comprehensive Reading II & $\square$ Yes $\square$ No & (4) & (3) & (2) & (1) \\
\hline
\end{tabular}

(4) Please rate how strongly you agree or disagree with the following statements about your developmental classes.

Example: (4) - (2) (1)

\begin{tabular}{|c|c|c|c|c|}
\hline & $\begin{array}{c}\text { Strongly } \\
\text { Agree }\end{array}$ & Agree & Disagree & $\begin{array}{c}\text { Strongly } \\
\text { Disagree }\end{array}$ \\
\hline a. I know I need to brush up on my skills & (4) & (3) & (2) & (1) \\
\hline b. I resent having to take developmental classes & (4) & (3) & (2) & (1) \\
\hline $\begin{array}{l}\text { c. The other students in my classes seem more advanced } \\
\text { than I am }\end{array}$ & (4) & (3) & (2) & (1) \\
\hline $\begin{array}{l}\text { d. Some of the other students in my classes are way over } \\
\text { their heads }\end{array}$ & (4) & (3) & (2) & (1) \\
\hline $\begin{array}{l}\text { e. Without taking a brush-up class, I don't think I would be } \\
\text { able to make it in the next level }\end{array}$ & (4) & (3) & (2) & (1) \\
\hline $\begin{array}{l}\text { f. I could have passed the next level class without taking } \\
\text { the developmental course first }\end{array}$ & (4) & (3) & (2) & (1) \\
\hline $\begin{array}{l}\text { g. I tried to retest when I found out I needed a } \\
\text { developmental course }\end{array}$ & (4) & (3) & (2) & (1) \\
\hline
\end{tabular}

Comments or opinions about your developmental classes: 
5 Please check yes or no to indicate which things your advisor did when you met with him or her to sign up for fall classes. Then, for each activity that you checked yes, rate how much you think you will benefit from that activity.

$$
\text { Example: } \square \text { Yes } \square \text { No । }
$$
advisor did?

\section{My advisor:}
a. Talked to me without an appointment
b. Explained why I needed to take a developmental course
c. Hurried me through picking my classes for the semester
d. Took plenty of time helping me plan out what to take the next few semesters
e. Described the differences between two course options
Did your advisor do the activity?

$\square$ Yes $\square$ No Very
Helpful Helpful

(4)

(3)

Sort of Not at all (2)

$\square$ Yes $\square$ No (4) (3) (2) (1)

$\square$ Yes $\square$ No (4) (3) (2) (1)

$\square$ Yes $\square$ No (4) (3) (2) (1)

$\square$ Yes $\square$ No

(4)

(3)

(2)

f. Asked me questions about why I picked my major

$\square$ Yes $\square$ No (4)

g. Told me how to get a waiver from developmental classes

$\square$ Yes $\square$ No

(4)

(3)

(2)

h. Asked me what time of day I usually concentrate best

$\square$ Yes $\square$ No (4) (3) (2) (1)

i. Explained the importance of having the basic skills necessary for college success

$\square$ Yes $\square$ No (4)

(4) (3)

(2)

(1)

j. Told me how well past students who took developmental courses have done in school

$\square$ Yes $\square$ No (4) (3) (2) (1)

k. Reassured me that lots of students need to take brush-up courses

$\square$ Yes $\square$ No

(4)

(3)

(2)

I. Explained the course requirements in my major

m. Helped me realize what to expect from my

classes

$\square$ Yes $\square$ No (4)

(3)

(2)

(1)

$\square$ Yes $\square$ No

(4)

(3)

(2)

(1) while in college

$\square$ Yes $\square$ No (4) (3) (2)

(1)

0. Suggested I get a tutor at the start of the semester

$\square$ Yes $\square$ No

(4) (3)

(2) (1)

p. Helped me make a long-range plan for finishing my degree

$\square$ Yes $\square$ No (4)

q. Discussed study skills with me

$\square$ Yes $\square$ No

(4)

(3)

(2)

(1)

r. Asked me about my past academic performance

$\square$ Yes $\square$ No

(4)

(3)

(2)

s. Helped me explore career options

$\square$ Yes $\square$ No

(4)

(3)

(2)

(3)

(2)

(continued on next page) 
My advisor:

t. Explained registration procedures

Did your advisor do the activity?

How helpful were the things your advisor did?

u. Helped me think about balancing work hours with school hours

$\square$ Yes $\square$ No

Very Helpful

Helpful $\quad \begin{array}{ll}\text { Sort of } \\ \text { Helpful }\end{array}$

Not at all

(4)

(3)

(2)

(1)

$\square$ Yes $\square$ No

(4)

(3)

(2)

(1)

v. Encouraged me to get involved with a study group

$\square$ Yes $\square$ No (4)

(3)

(2)

w. Asked me to check back in with him/her several times during the semester

$\square$ Yes $\square$ No

(4)

(3)

(2)

(1)

6 In what ways do you believe the things your advisor said and did influenced your performance in both developmental and college level classes?

Example: (4) (2) (1)

\section{After talking to my advisor:}

Strongly

Agree

(4)

(4)

(4)

(3)

(3)

(2)

(1)

b. I became determined to prove that I could succeed in college

c. I felt better about taking a developmental course

d. I felt worried about whether I could make it in college level courses

e. I felt discouraged

f. I felt better able to talk with other faculty

g. I followed at least one piece of advice my advisor gave me

h. I'm doing better in my developmental classes because of the advice my advisor gave me

i. I'm doing better in my college level classes because of the advice my advisor gave me

(4)

(3)

(4)

(3)

(4)

(3)

(2)

(1)

(4)

(3)

(4)

(3)

(2)

(1)

(4)

(3)

(2)

(1)

(2)

(1)

Comments or opinions about your advisor:

Thank you for sharing your opinions! Please return the questionnaire to your instructor. 


\section{ATTITUDES TOWARD UNDERPREPARED STUDENTS}

\section{TRADITIONAL*}

2c. Wanted me to sign up for as many credits as possible first semester

2e. Acted like I should already be ready to handle college courses

2i. Thought I should make school my number one priority, no matter what

4d. Some of the other students in my classes are way over their heads

\section{INTERACTIONAL}

2d. Wanted me to understand how brushing-up on my skills would help me

2f. Tried to balance my schedule with easy and hard courses

2g. Cared whether I was satisfied with my schedule

2h. Wanted to help me do the best I could in school

2j. Understood my goals and priorities for school

4c. The other students in my classes seem more advanced than I am

\section{ATTITUDES TOWARD DEVELOPMENTAL PLACEMENT POLICY}

\section{LAISSEZ-FAIRE *}

2b. Didn't think I should have to take any developmental courses

4b. I resent having to take developmental classes

4f. I could have passed the next level class without taking the developmental course first

4g. I tried to retest when I found out I needed a developmental course

* Items categorized as Traditional or Laissez-Faire will be reverse scored.

\section{STRUCTURED}

2a. Thought that the developmental courses would be good for me

3. How much do you think you will benefit from taking the course (Average of the rating for all developmental courses the student is required to take counts as 1 of 8 items measuring student's attitude)

4a. I know I need to brush up on my skills

4e. Without taking a brush-up class, I don't think I would be able to make it in the next level 


\section{Appendix K: Item Categorization Matrix for Part 5 of the Student Advising Questionnaire}

\begin{tabular}{|c|c|}
\hline \multicolumn{2}{|r|}{$\begin{array}{l}\text { Advising Activities Unique to the Prescriptive Model } \\
\end{array}$} \\
\hline 5c. & Hurried me through picking my classes for the semester \\
\hline & Advising Activities Consistent to Both the Prescriptive and Developmental Models \\
\hline $5 a$. & Talked to me without an appointment \\
\hline $5 \mathrm{~g}$. & Told me how to get a waiver from developmental classes \\
\hline 51. & Explained the course requirements in my major \\
\hline $5 r$. & Asked me about my past academic performance \\
\hline 5t. & Explained registration procedures \\
\hline \multicolumn{2}{|r|}{ Advising Activities Unique to the Developmental Model } \\
\hline $5 b$. & Explained why I needed to take a developmental course \\
\hline $5 d$. & Took plenty of time helping me plan out what to take the next few semesters \\
\hline $5 e$. & Described the differences between two course options \\
\hline $5 f$. & Asked me questions about why I picked my major \\
\hline $5 \mathrm{~h}$. & Asked me what time of day I usually concentrate best \\
\hline $5 i$ & Explained the importance of having the basic skills necessary for college success \\
\hline $5 j$. & Told me how well past students who took developmental courses have done in school \\
\hline $5 k$. & Reassured me that lots of students need to take brush-up courses \\
\hline 5m. & Helped me realize what to expect from my classes \\
\hline $5 n$. & Talked to me about how to manage my time while in college \\
\hline 50. & Suggested I get a tutor at the start of the semester \\
\hline $5 p$. & Helped me make a long-range plan for finishing my degree \\
\hline $5 q$. & Discussed study skills with me \\
\hline $5 s$. & Helped me explore career options \\
\hline $5 u$. & Helped me think about balancing work hours with school hours \\
\hline $5 \mathrm{v}$. & Encouraged me to get involved with a study group \\
\hline $5 \mathrm{w}$. & Asked me to check back in with him/her several times during the semester \\
\hline
\end{tabular}


Follow-up Questions for AAS Pilot Participants:

1. How long did filling out the survey take you?

2. What were your impressions of the cover letter? Was the study's purpose clear? Do you think that advisors will respond well to the letter and be willing to fill out the survey? Do you have any suggestions on how to change the wording so that advisors are more likely to respond well?

3. What are your overall visual impressions of the survey in terms of format and readability?

4. Are all directions clear? Did you always know where and how to mark your answers?

5. Were any questions unclear to you so that you weren't quite sure what was being asked?

6. Do you sense any bias in the questions that might influence respondents to answer in a particular way?

7. Are questions worded in a way that will elicit truthful answers?

8. Do you think that advisors will see any value in answering the survey questions?

9. Do you have any suggestions other suggestions on how I could improve the survey?

\section{Follow-up Questions for SAQ Pilot Participants:}

1. How long did it take you to complete the survey?

2. How does the questionnaire look to you? In terms of overall format, was it easy to read?

3. Did you find any of the directions confusing? Did you always know where and how to mark your answers?

4. Were any of the questions hard to understand so that you weren't quite sure what was being asked?

5. Are there any words on the survey that you don't think other students will know?

6. Do you have any suggestions on how I could improve the survey to make it easier to read or understand? 